UNITED STATES DEPARTMENT OF THE INTERIOR

GEOLOGICAL SURVEY

\title{
METAMORPHIC HISTORY OF ALASKA
}

\author{
By
}

Cynthia Dusel-Bacon

Open-File Report 91-556

This report is preliminary and has not been edited or reviewed for conformity with U.S. Geological Survey editorial standards or with the North American Stratigraphic Code. Any use of trade, firm, or product names is for descriptive purposes only and does not imply endorsement by the U.S. Government.

1 Menlo Park, CA 94025 


\section{United States Department of the Interior GEOLOGICAL SURVEY \\ Branch of Alaskan Geology \\ 345 Middlefield Road, MS-904 \\ Menlo Park, Califomia 94025-3591}

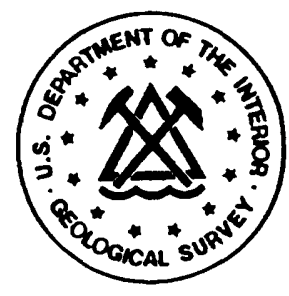

December 30, 1991

Errata for Sheet 1 (Map and Table Showing Metamorphic Rocks of Alaska) of USGS Open-File Report 91-556 (Metamorphic History of Alaska) by Cynthia Dusel-Bacon

It has just been brought to my attention that incorrect latitudes and longitudes were put on the base map used for sheet 1 . Please cross out the incorrect latitude and longitude values around the borders of the map (given in parentheses in the following list) and write in the correct values (given in bold face type) on your copy of the map. For example: (59) 65; means, cross out $59^{\circ}$ and write in $65^{\circ}$.

From left to right across top of sheet 1 :

(163) 175 ; (161) 170 ; (159) 165 ; (157) 160 ; (155) stays as is; (153) 150 ; (151)

145; (149) 140; (147) 135; (145) 130; (143) 125; (141) 120; (139) 115; (137) 110

From left to right across bottom of sheet 1 :

(159) 165 ; (157) 160 ; (155) stays as is; (153) 150; (151) 145 ; (149) 140 ; (147)

$135 ;(145) 130$

From top to bottom of left-hand side of sheet 1 :

(163) 175 ; (59) 65 ; (161) 170 ; (57) 60; (55) stays as is;

From top to bottom of right-hand side of sheet 1 :

(59) 65 ; (139) 115 ; (57) 60 ; (141) 120 ; (55) stays as is; (143) 125

Please accept my apologies for the inconvenience.

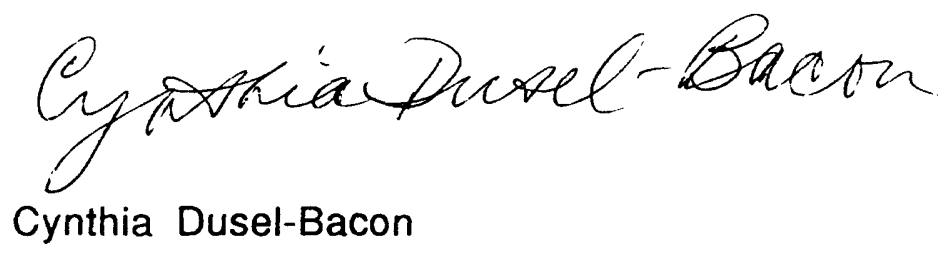




\section{CONTENTS}

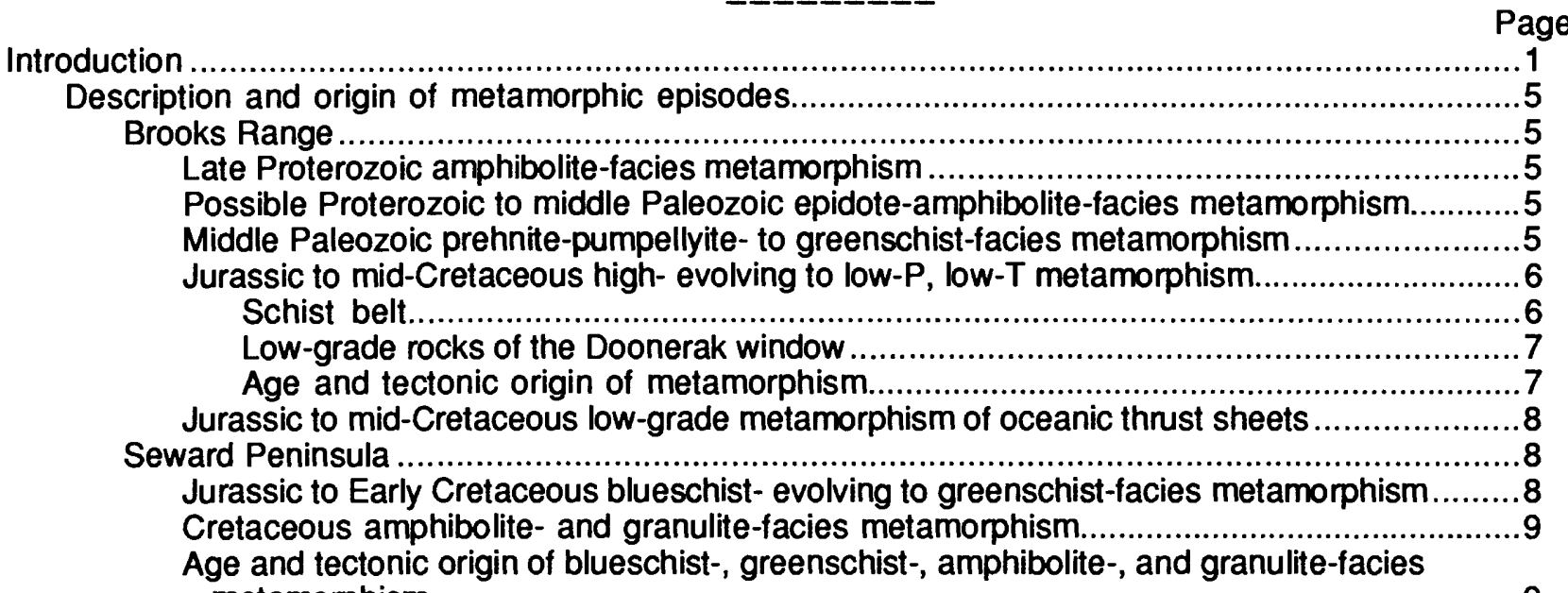

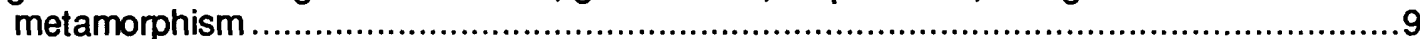

Probable Jurassic to Early Cretaceous blueschist-facies metamorphism............................10

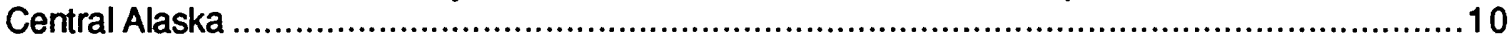

Pre-middle Paleozoic greenschist- and amphibolite-facies metamorphism.......................10

Pre-Early Cretaceous greenschist- and amphibolite-facies metamorphism.........................11

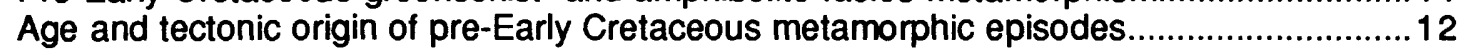

Mesozoic low-grade, locally high-P, metamorphism...................................................12

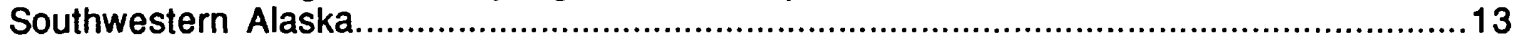

Early Proterozoic amphibolite-facies metamorphism...............................................13

Low-grade, locally high-P, Mesozoic metamorphism of oceanic rocks................................13

Yukon-Tanana upland and Alaska Range north of the McKinley and Denali faults......................16

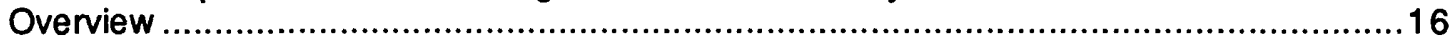

Early Paleozoic(?) high-P, high-T metamorphism .................................................16

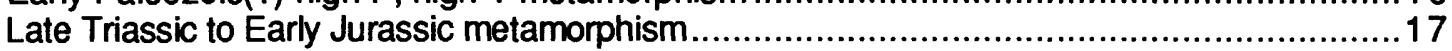

Paleozoic or Mesozoic metamorphism of uncertain age and origin ..................................18

Early Cretaceous metamorphism of augen gneiss-bearing unit..................................18

Early to Late Cretaceous metamorphism of other units ............................................... 19

Problematic tectonic origin of Cretaceous metamorphism and an alternative interpretation

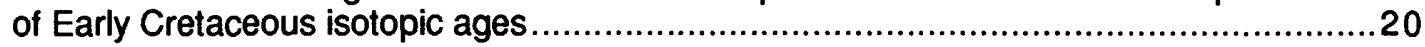

Area of southern Alaska between the McKinley and Denali faults and the Border Ranges

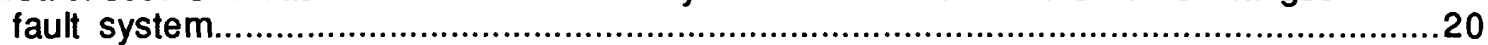

Jurassic metamorphism in the Peninsular and Wrangellia terranes..................................20

Possible correlatives of Jurassic metamorphism of the Peninsular and Wrangellia terranes

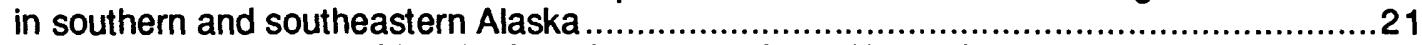

Medium-grade metamorphism in the adjacent northern Alexander terrane.............................22

Post-Early Jurassic to pre-mid-Cretaceous(?) low-grade metamorphism of the Wrangellia

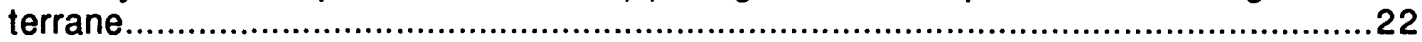

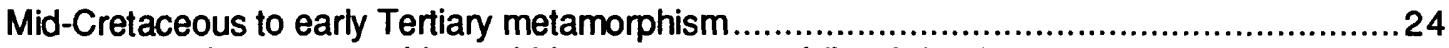

Low-grade metamorphism within a compressed flysch basin...................................24

Intermediate-P metamorphism of the Maclaren metamorphic belt ................................24

Area of southern and southeastern Alaska that lies south of the Border Ranges fault system.....25

Jurassic blueschist- to greenschist-facies metamorphism ............................................25

Jurassic to early Tertiary low-grade metamorphism of Chugach and Yakutat terranes mélange ..............................................................................................27

Late Cretaceous to early Tertiary low-P metamorphism of Chugach and Yakutat terranes

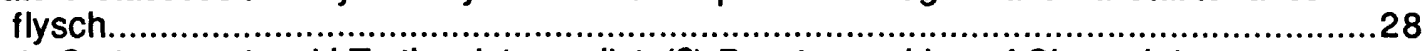

Late Cretaceous to mid-Tertiary intermediate(?)-P metamorphism of Chugach terrane

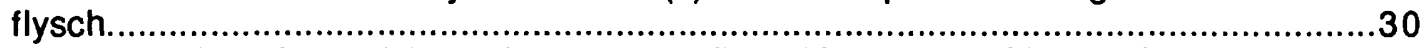

Retrograde effects in overlying units corresponding with metamorphism and underthrusting of Chugach terrane flysch ...............................................................30

Early Tertiary low-grade metamorphism of Prince William and Ghost Rocks terranes..............31 


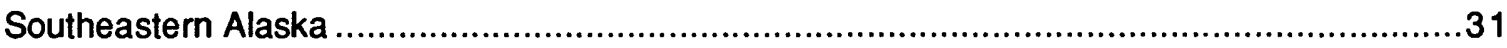

Middle Cambrian to Early Ordovician metamorphism.....................................................31

Silurian to earliest Devonian low- to medium-grade metamorphism ................................32

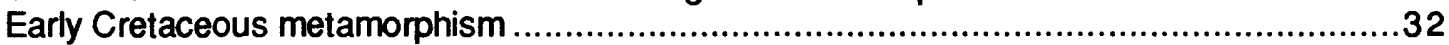

Mid-Cretaceous low-grade metamorphism.....................................................................33

Early Late Cretaceous intermediate-P metamorphism associated with the intrusion of

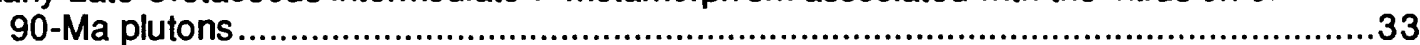

Late Cretaceous to early Tertiary synkinematic metamorphism and plutonism ...................34

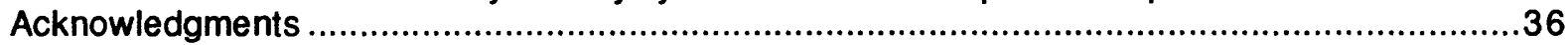

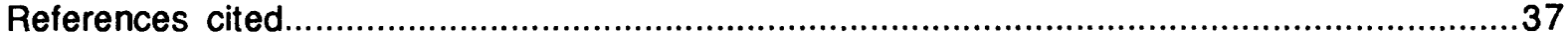

\section{ILLUSTRATIONS}

SHEETS 1. and 2. Map and table showing metamorphic rocks of Alaska

FIGURE 1. Diagram showing schematic representation of metamorphic-facies groups

2. Map showing area of reports in the series of metamorphic studies of Alaska...........3

3. Map showing lithotectonic terranes and metamorphic facies units in southwestern Alaska

\section{TABLES}

TABLE 1. Scheme for determining metamorphic facies ........................................2

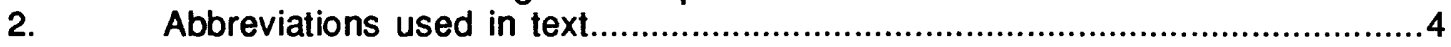




\section{INTRODUCTION}

This report presents a summary of the major, regionally developed, metamorphic episodes that affected Alaska throughout the evolution and accretion of its many lithotectonic terranes. Sheets 1 and 2 (Map and table showing metamorphic rocks of Alaska) that accompany this report are a 1:2,500,000-scale Metamorphic facies map of Alaska and a summary of metamorphic units on the metamorphic map. This open-file report will be superseded by Dusel-Bacon (in press a), a chapter of the Alaskan volume of the Geological Society of America's publication commemorating the Decade of North American Geology, and the associated colored version of the metamorphic facies map (Dusel-Bacon, in press). The metamorphic scheme (Zwart and others, 1967) used for the map (fig. 1; table 1) is based on the occurrence of pressure- and temperature-sensitive metamorphic minerals. Regionally metamorphosed rocks are divided into four facies groups, each of which reflects a different grade of metamorphism. In order of increasing temperatures of crystallization they are: (1) laumontite and prehnite-pumpellyite facies (LPP); (2) greenschist facies (GNS); (3) epidote-amphibolite and amphibolite facies (AMP); and (4) two-pyroxene (granulite) facies (2PX), which occurs only on the Seward Peninsula. Where possible, the greenschist-facies and the epidote-amphibolite- and amphibolite-facies groups are further divided on the basis of pressure of crystallization into three facies series: high-, intermediate-, or low-pressure series. These facies series are indicated by an $\mathrm{H}, \mathrm{I}$, or $\mathrm{L}$ in place of the final letter in the symbol used for the facies group. The metamorphic facies symbol for each episode is followed by a symbol showing the age of metamorphism or its minimum and maximum age limits. Subscripts are used to differentiate units that have the same metamorphic grade and age but that have different protoliths and are believed to have different metamorphic histories.

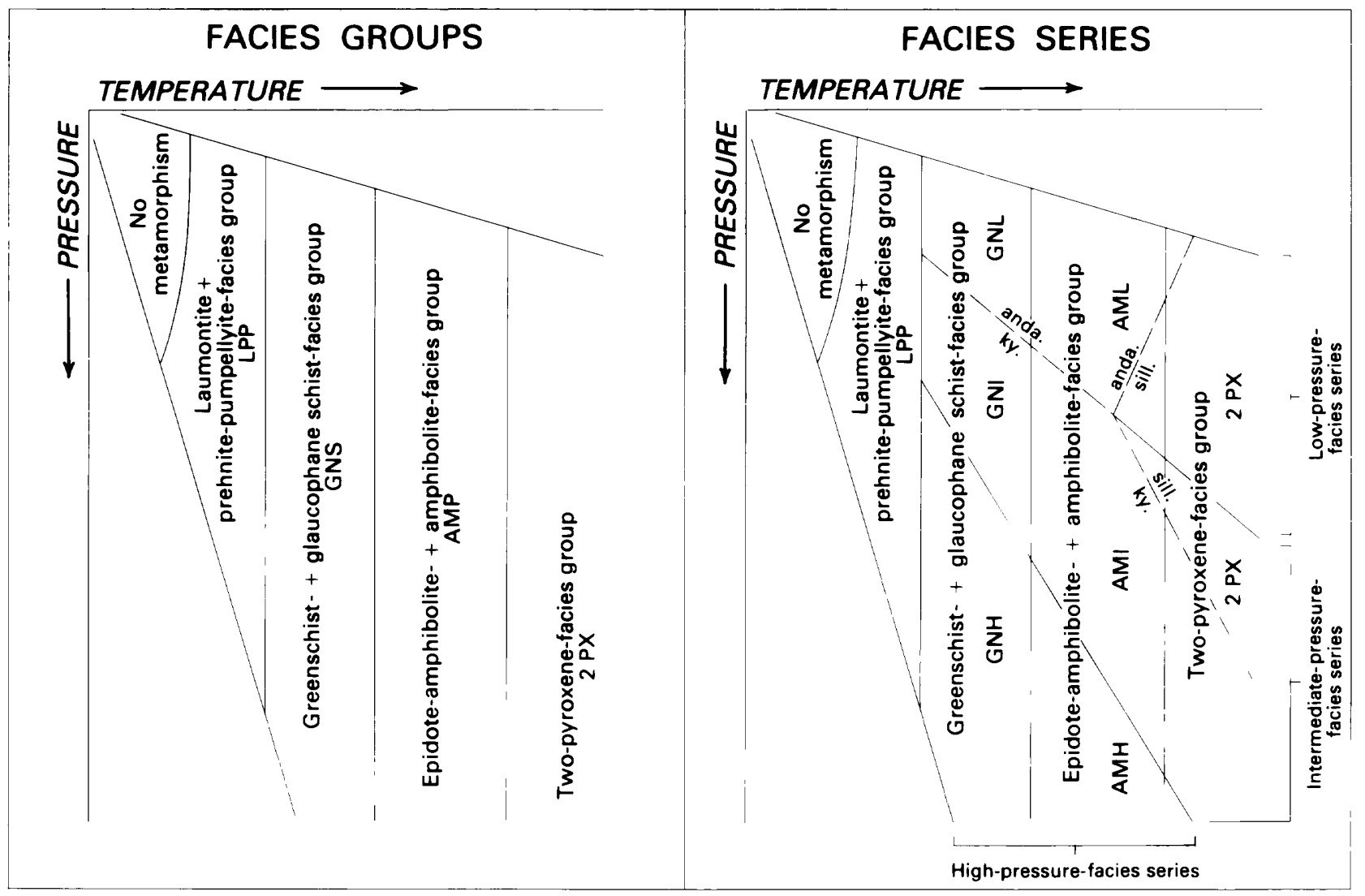

Figure 1.--Schematic representation of metamorphic-facies groups and series in P-T space and their letter symbols used on sheets 1 and 2 (modified from Zwart and others, 1967). Stability fields of $\mathrm{Al}_{2} \mathrm{SiO}_{5}$ polymorphs andalusite (anda.), kyanite (ky.), and sillimanite (sill.) shown by dashed lines. 
Table 1.-Scheme for determining metamorphic facies

[Modified from Zwart and others, 1967]

\begin{tabular}{llll}
\hline $\begin{array}{c}\text { Facies } \\
\text { symbol }\end{array}$ & $\begin{array}{c}\text { Diagnostic minerals } \\
\text { and assemblages }\end{array}$ & $\begin{array}{c}\text { Forbidden minerals } \\
\text { and assemblages }\end{array}$ & $\begin{array}{c}\text { Common } \\
\text { minerals and } \\
\text { assemblages }\end{array}$ \\
\hline
\end{tabular}

\section{LAUMONTITE AND PREHNITE-PUMPELLYITE FACIES}

\begin{tabular}{|c|c|c|c|c|}
\hline LPP & $\begin{array}{l}\text { Laumontite + quartz, } \\
\text { prehnite + pumpellyite. }\end{array}$ & $\begin{array}{l}\text { Pyrophyllite, analcime - } \\
\text { quartz, heulandite. }\end{array}$ & $\begin{array}{l}\text { "Chlorite", saponite. } \\
\text { dolomite + quartz. } \\
\text { ankerite + quartz, } \\
\text { kaolinite, montmoril. } \\
\text { lonite, albite. } \\
\text { K-feldspar, "white mica" }\end{array}$ & $\begin{array}{l}\text { Epidote. actinolite. and } \\
\text { "sphene" possible in } \\
\text { prehnite-pumpellyite } \\
\text { facies. }\end{array}$ \\
\hline
\end{tabular}

\section{GREENSCHIST FACIES}

\begin{tabular}{|c|c|c|c|c|}
\hline GNS & & $\begin{array}{l}\text { Staurolite, andalusite. } \\
\text { cordierite, plagioclase } \\
\text { (An>10), laumontite + } \\
\text { quartz, prehnite + } \\
\text { pumpellyite. }\end{array}$ & $\begin{array}{l}\text { Epidote, chlorite. } \\
\text { chloritoid, albite. } \\
\text { muscovite, calcite. } \\
\text { dolomite, actinolite, } \\
\text { talc. }\end{array}$ & \\
\hline \multicolumn{5}{|c|}{ Low- and intermediate-pressure greenschist facies } \\
\hline GNL and GNI & & $\begin{array}{l}\text { Homblende, glaucophane. } \\
\text { crossite, lawsonite. } \\
\text { jadeite + quartz. } \\
\text { aragonite. }\end{array}$ & & $\begin{array}{l}\text { Biotite and manganterous } \\
\text { garnet possible, stilpno- } \\
\text { melane mainly restricted } \\
\text { to intermediate-pressure } \\
\text { greenschist facies }\end{array}$ \\
\hline \multicolumn{5}{|c|}{ High-pressure greenschist (blueschist) facies } \\
\hline GNH & $\begin{array}{l}\text { Glaucophane, crossite. } \\
\text { aragonite, jadeite }+ \\
\text { quartz. }\end{array}$ & , & $\begin{array}{l}\text { Aimandine, paragonite. } \\
\text { stilpnomelane }\end{array}$ & $\begin{array}{l}\text { Subcalcic hornblende } \\
\text { (barroisite) may occur in } \\
\text { highest temperature part } \\
\text { of this facies. }\end{array}$ \\
\hline \multicolumn{5}{|c|}{ Low-temperature subfacies of high-pressure greenschist facies } \\
\hline $\begin{array}{l}\text { GNH } \\
\text { (with } \\
\text { stipple, pl.1) }\end{array}$ & $\begin{array}{l}\text { Above minerals plus } \\
\text { pumpellyite and (or) } \\
\text { lawsonite. }\end{array}$ & & & \\
\hline
\end{tabular}

EPIDOTE-AMPHIBOLITE AND AMPHIBOLITE FACIES

\begin{tabular}{|c|c|c|c|c|}
\hline AMP & Staurolite. & $\begin{array}{l}\text { Orthopyroxene + } \\
\text { clinopyroxene, } \\
\text { actinolite + calcic } \\
\text { plagioclase + quartz. } \\
\text { glaucophane. }\end{array}$ & $\begin{array}{l}\text { Hornblende, plagio- } \\
\text { clase, garnet. biotite. } \\
\text { muscovite, diopside. } \\
\text { K-feldspar, rutile. cal- } \\
\text { cite, dolomite, scapolite }\end{array}$ & \\
\hline \multicolumn{5}{|c|}{ Low-pressure amphibolite facies } \\
\hline AML & $\begin{array}{l}\text { Andalusite + staurolite, } \\
\text { cordierite + orthoamphi- } \\
\text { bole. }\end{array}$ & Kyanite. & $\begin{array}{l}\text { Cordierite. sillimanite. } \\
\text { cummingtonite }\end{array}$ & $\begin{array}{l}\text { Pyralspite garnet rare in } \\
\text { lowest possible pressure } \\
\text { part of this facies }\end{array}$ \\
\hline \multicolumn{5}{|c|}{ Intermediate- and high-pressure amphibolite facies } \\
\hline$A M I$ and $A M H$ & Kyanite + staurolite. & Andalusite. & & $\begin{array}{l}\text { Sillimanite mainly re- } \\
\text { stricted to intermediate- } \\
\text { pressure amphibolite } \\
\text { facies }\end{array}$ \\
\hline \multicolumn{5}{|c|}{ TWO-PYROXENE FACIES } \\
\hline $2 \mathbf{P X}$ & $\begin{array}{l}\text { Orthopyroxene+ } \\
\text { clinopyroxene. }\end{array}$ & $\begin{array}{l}\text { Staurolite, orthoamphi- } \\
\text { bole, muscovite. epidote. } \\
\text { zoisite. }\end{array}$ & $\begin{array}{l}\text { Hypersthene, clinopyrox- } \\
\text { ene. garnet, cordierite. } \\
\text { anorthite, K-feidspar. } \\
\text { sillimanite, biotite. } \\
\text { scapolite. calcite. dolo- } \\
\text { mite, rutile }\end{array}$ & $\begin{array}{l}\text { Hornblende possible } \\
\text { Kyanite may occur in high } \\
\text { er pressure part of this } \\
\text { facies and periclase and } \\
\text { wollastonite in low. } \\
\text { pressure part }\end{array}$ \\
\hline
\end{tabular}


Sheet 2 gives summary information for each map unit, including the number by which the unit is referred to in this report; the facies and age designation of the unit; the lithotectonic terrane(s) in which the unit occurs; the lithology and age range of the protoliths; the metamorphic rock types and minerals; and the known, minimum, and (or) maximum age of metamorphism and the evidence for the three types of ages. Most, but not all, of the units shown on sheets 1 and 2 are discussed in this report. The reader is referred to four more detailed, regional metamorphic reports and accompanying 1:1,000,000-scale metamorphic facies maps on Alaska (fig. 2) for sources of information and a more complete discussion and listing of references for all the units shown on sheets 1 and 2.

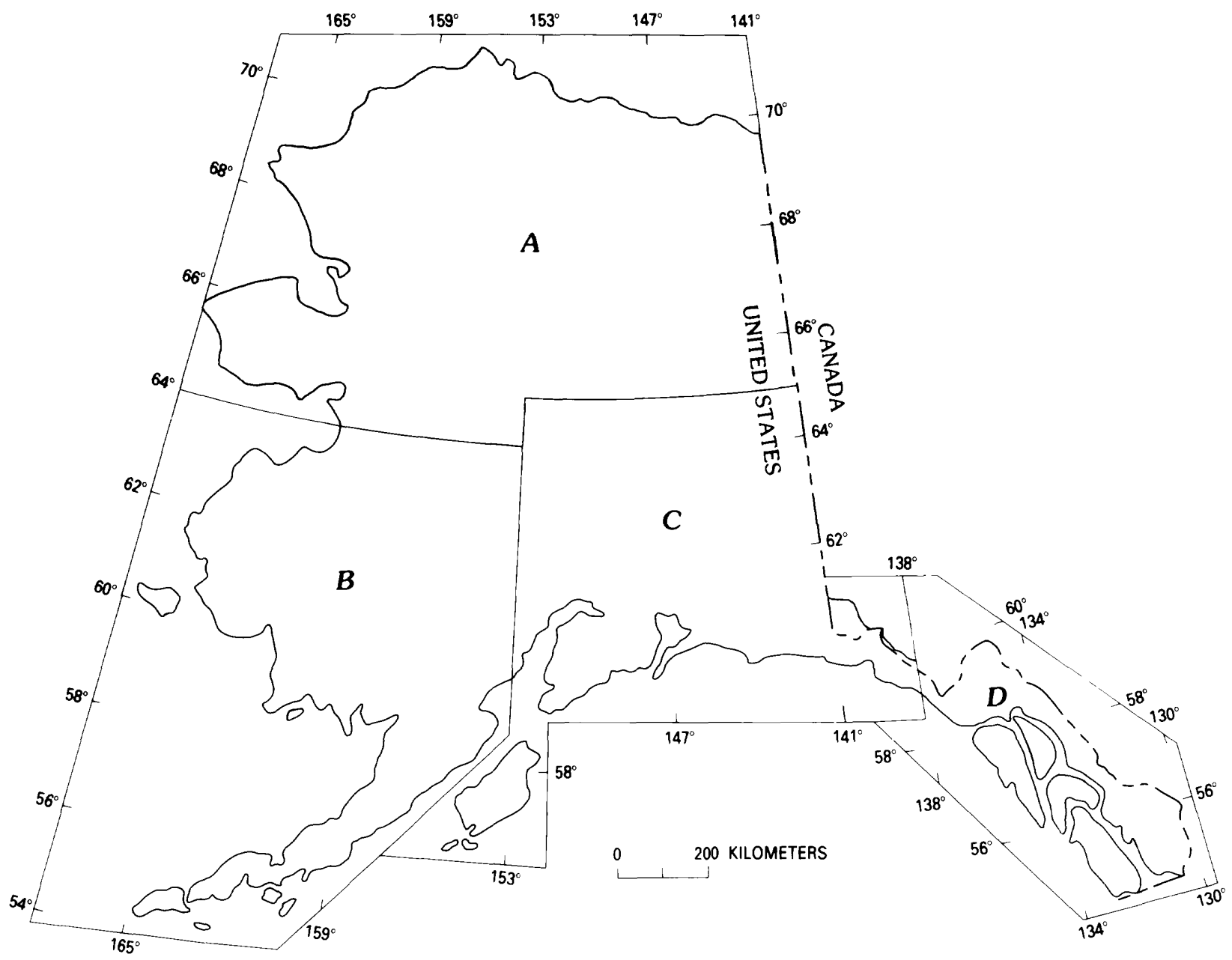

Figure 2.--Map showing areas of study in the series of metamorphic facies reports of Alaska. A, DuselBacon and others (1989); B, Dusel-Bacon, Doyle, and Box (in press); C, Dusel-Bacon, Csejtey, and others (in press); D, Dusel-Bacon, Brew, and Douglass (in press) and Dusel-Bacon and others (1991). 
Where sufficient data are available, the possible tectonic origin of a given metamorphic episode is discussed. Unless otherwise defined, all lithotectonic terranes are those of Jones and others (1987) west of the $141^{\text {st }}$ meridian and of Monger and Berg (1987) east of it. All radiometric ages cited have been calculated or recalculated using the decay constants of Steiger and Jäger (1977). The DNAG Time Scale (Palmer, 1983) is adopted in relating radiometric ages to geologic time. Abbreviations used in this report are explained in table 2.

\section{TABLE 2. ABBREVIATIONS USED IN TEXT}

\begin{tabular}{|c|c|}
\hline $\begin{array}{l}\text { CAl } \\
M_{1}\end{array}$ & $\begin{array}{l}\text { conodont alteration index of Epstein and others (1977) } \\
\text { first metamorphic episode of polymetamorphic unit }\end{array}$ \\
\hline $\begin{array}{l}M_{1} \\
M_{2}\end{array}$ & $\begin{array}{l}\text { first metamorphic episode of polymetamorphic unit } \\
\text { second metamorphic episode of polymetamorphic unit }\end{array}$ \\
\hline$S_{1}$ & fabric formed during first metamorphic episode \\
\hline$S_{2}$ & fabric formed during second metamorphic episode \\
\hline $\mathbf{P}$ & pressure \\
\hline$T$ & temperature \\
\hline$a b$ & albite \\
\hline ac & actinolite \\
\hline amph & amphibole \\
\hline anda & andalusite \\
\hline $\begin{array}{l}\text { bar amph } \\
\text { bt }\end{array}$ & $\begin{array}{l}\text { barroisitic amphibole } \\
\text { biotite }\end{array}$ \\
\hline ch & chlorite \\
\hline$\infty$ & cordierite \\
\hline $\operatorname{cpx}$ & clinopyroxene \\
\hline 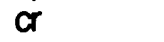 & crossite \\
\hline ctd & chloritoid \\
\hline ep & epidote group mineral \\
\hline gl & glaucophane \\
\hline gt & garnet \\
\hline hb & hornblende \\
\hline jd & jadeite \\
\hline jdpx & jadeitic pyroxene \\
\hline if & potassium feldspar \\
\hline ky & kyanite \\
\hline iw & lawsonite \\
\hline $\mathrm{mu}$ & muscovite \\
\hline pa & paragonite \\
\hline $\mathrm{pl}$ & plagioclase \\
\hline pr & prehnite \\
\hline pu & pumpellyite \\
\hline$q z$ & quartz \\
\hline sil & sillimanite \\
\hline sp & spinel \\
\hline sph & sphene \\
\hline st & staurolite \\
\hline tr & tremolite \\
\hline wm & white mica \\
\hline
\end{tabular}




\title{
DESCRIPTION AND ORIGIN OF METAMORPHIC EPISODES
}

\author{
BROOKS RANGE
}

\section{Late Proterozoic amphibolite-facies metamorohism}

A sequence of polymetamorphosed amphibolite-facies rocks recrystallized to greenschist- and blueschist-facies assemblages (unit 1) crops out in the Baird Mountains of the southwestern Brooks Range. The sequence includes pelitic schist, minor amounts of interlayered quartzite, marble, and metabasite, and crosscutting intermediate to mafic metaplutonic rocks. It makes up the Hub Mountain terrane of Mayfield and others (1982). Mineral assemblages formed during $\mathrm{M}_{1}$ include $\mathrm{gt}, \mathrm{hb}$, and $\mathrm{pl}$ in metabasite, and bt and $\mathrm{gt}$ in pelitic schist (A.B. Till, written commun., 1987). A Late Proterozoic age for $M_{1}$ is indicated by $K$-Ar ages on mu and $\mathrm{hb}$ between $729 \pm 22$ and $594 \pm 18 \mathrm{Ma}$ (Turner and others, 1979; Mayfield and others, 1982), and by an $\mathrm{Rb}-\mathrm{Sr}$ mineral-whole rock isochron age of $686 \pm 116 \mathrm{Ma}$ (Armstrong and others, 1986). This metamorphic episode is the oldest recorded anywhere in the Brooks Range and is the only documented evidence of Proterozoic metamorphism in the region.

Most $M_{1}$ assemblages have been partially or, locally, totally recrystallized to greenschist- and blueschistfacies assemblages during subsequent Mesozoic metamorphism $\left(M_{2}\right)$. Common $M_{2}$ minerals are ch, ep, wm, ab, sp, bar amph, ac, and bl amph (A.B. Till, written commun., 1987). Recent unpublished mapping indicates that blueschist-facies assemblages are most prevalent in rocks that lie structurally above and below thrust slices of the amphibolite-facies rocks (A.B. Till, written commun., 1987). $M_{2}$ is attributed to a high-P evolving to low-P, low-T metamorphic episode that affected the entire southern Brooks Range (unit 3 and $M_{2}$ of unit 2) between Middle Jurassic and mid-Cretaceous time (discussed in a later section).

\section{Possible Proterozoic to middle Paleozoic epidote-amphibolite-facies metamomhism}

Areas of epidote-amphibolite-facies rocks partly recrystallized to lower grade assemblages crop out in the central Brooks Range (unit 2). By analogy with unit 1, they may also record pre-Mesozoic metamorphism. These areas consist of polymetamorphosed pelitic, feldspathic, and graphitic schist, quartzite, marble, orthogneiss, and metabasite. Protoliths are older than the Middle Devonian granitoids and, between longitudes 151 and $153^{\circ}$, are older than the Proterozoic(?) or pre-middle Paleozoic granitoids (Dillon and others, 1980) that intrude them. It is unclear, however, whether the granitoids, shown with the pattern that denotes a metamorphosed pluton, were metamorphosed prior to the widespread Mesozoic episode that affected the entire southern Brooks Range.

In general, the metamorphic rocks of this unit are distinguished from contiguous rocks of unit 3 by having a coarser crystallinity, relict epidote-amphibolite-facies mineral assemblages, and a more complex structural fabric (Hitzman and others, 1982; Dillon and others, 1987). The structural fabric includes a penetrative fabric that predates that developed in unit 3 , as well as one or more younger penetrative fabrics also present in unit 3.

\section{Middle Paleozoic prehnite-pumpellyite- to areenschist-facies metamorphism}

Low- to medium-grade metasedimentary, metavolcanic, and metacarbonate rocks of Proterozoic to Middle(?) and Late Devonian protolith age crop out in the Romanzof and Davidson Mountains in the eastern Brooks Range. In the Romanzof Mountains, metamorphic grade increases southward from prehnitepumpellyite facies (unit 11) to greenschist facies (unit 12). The metamorphic contact between these units was probably gradational, although it has been subsequently modified by thrust faulting (Dusel-Bacon and others, 1989). Metamorphism predates the Mississippian age of unmetamorphosed rocks that unconformably overlie these units and postdates the Middle(?) Devonian protolith age of the youngest metasedimentary rocks (Sable, 1977; Dusel-Bacon and others, 1989).

The indicated range in metamorphic age is similar to the Devonian intrusive age (380 $\pm 10-\mathrm{Ma} \mathrm{U}-\mathrm{Pb}$ upper intercept age of zircon; Dillon and Bakke, 1987) of a peraluminous batholith that intrudes units 11 and 12 , suggesting that metamorphism and plutonism may have been products of the same tectonic regime. Parts of the batholith are gneissic and mylonitically or cataclastically deformed (Sable, 1977), but the age of this deformation is uncertain. Structural data collected from greenschist-facies rocks in the western end of unit 12 suggest that the pre-Mississippian rocks in that area were transported southeastward during Middle Devonian (Ellesmerian?) thrusting (Oldow and others, 1987). Additional studies are needed to determine the nature and extent of the proposed southeastward-thrusting event and its temporal relation to the metamorphism.

Isotopic and structural data (Sable, 1977; Dillon, 1987; Oldow and others, 1987) suggest that the rocks of units 11 and 12 and perhaps some parts of the adjacent unmetamorphosed rock unit in the Romanzof 
Mountains area were subsequently involved in Mesozoic and perhaps early Cenozoic deformation and metamorphism that was part of the widespread Jurassic and Early Cretaceous orogeny that affected the schist belt of the southern Brooks Range (unit 3 and related units).

In the Davidson Mountains, metamorphism of greenschist-facies rocks of unit 13 predated, but was associated with, intrusion of Late Devonian granitoids (Dusel-Bacon and others, 1989). This relationship is suggested by an increase in the metamorphic grade from the ch- to the bt-gt-zone with decreasing distance from the crosscutting Late Devonian plutons, and by the closeness in age between the maximum metamorphic age provided by the youngest protolith age (Late Devonian) and the intrusive age of the undeformed crosscutting granitoids..

\section{Jurassic to mid-Cretaceous high- evolving to low-P. low-T metamorphism}

\section{Schist belt}

A sequence of polydeformed blueschist- and greenschist-facies rocks (unit 3) crops out across almost the entire width of the southern Brooks Range. This metamorphic sequence, informally called the schist belt, consists of Devonian and older calcareous, pelitic, and graphitic metasedimentary rocks with volumetrically minor metacarbonate rocks, metarhyolite, metabasite, and granitoid orthogneiss (Dillon and others, 1980; Hitzman and others, 1982), and a subordinate amount of upper Paleozoic and locally Triassic metapelite and metacarbonate rocks along its northern margin. The rocks were metamorphosed during a single, prolonged, polyfacial episode and followed a clockwise P-T path that evolved from blueschist- to greenschist-facies conditions. This path reflects tectonic loading followed by decompresson. Two phases of penetrative deformation are recognized. Both are characterized by isoclinal folding, and their relation to each other suggests refolding of early formed isoclines during decompression (Gottschalk, 1987). In the Wiseman area, which is probably typical of much of the southern schist belt, lineations and fold axes plunge to the south, and rocks have undergone $\mathrm{N}$-vergent ductile-shear deformation concurrent with metamorphism (Gottschalk, 1987).

Most of the rocks in which the high-P minerals $\mathrm{gl}, \mathrm{Iw}$, and jdpx have been identified occur in a zone within the southern part of this unit (sheet 1). The restricted occurrence of these minerals may be due to compositional controls (most rocks whose composition favors the development of these minerals are restricted to this zone) or, in part, to structural controls, as proposed by Hitzman (1980). He observed that blueschist assemblages occurred within large nappe-like folds. Glaucophane is by far the most commonly developed high-P mineral and occurs in metabasite, iron-rich metasedimentary rocks, and metatuff (DuselBacon and others, 1989). The assemblage ky+ctd also occurs locally in iron-rich metasedimentary rocks, but it is not known whether the ky formed during the Jurassic to Cretaceous blueschist-to-greenschist episode or during the possible pre-Devonian episode discussed in the previous section.

The metamorphic grade and overall degree of deformation within unit 3 decreases to the north. The northern limit of this unit is defined, in part, on the basis of a CAl isotherm that delineates the first occurrence of CAl values of less than 5 (corresponding to a temperature of less than $300{ }^{\circ} \mathrm{C}$ ) for Ordovician through Triassic rocks (A.G. Harris, written commun., 1984). It is possible that the northern part of this unit never experienced the high-P episode recorded in the southern part, but available metamorphic and structural data collected by W.P. Brosgé and C.F. Mayfield during reconnaissance mapping of the region did not indicate a discrete change in the metamorphic history across the east-west strike of this unit. Future studies will undoubtedly define a more precise northem limit to the area that experienced early high-P metamorphism.

The high-P phase of the P-T path began in the low-T gl-Iw stability field and evolved into the higher T epgt-gl stability field. Evidence for this increase in T with time consists of inclusions composed of pseudomorphs of pa and ep after Iw within gt from metabasite at several localities across unit 3 (A.B. Till, oral commun., 1987). Jadeite+quartz has been identified in the Ambler River quadrangle (Gilbert and others, 1977; Turner and others, 1979), and jdpx occurs in eclogite about $200 \mathrm{~km}$ to the east near Wiseman (Gottschalk, 1987). Jadeite+quartz probably formed locally during the low-T phase of the high-P metamorphism. Such formation is compatible with mineral assemblage data from the area near the eclogite that suggest that the earliest phase of metamorphism occurred at $P>8 \mathrm{~kb}$ and $T \approx 450{ }^{\circ} \mathrm{C}$ and subsequently continued under blueschist- evolving to greenschist-facies conditions at $P<8 \mathrm{~kb}$ and $T \approx 480^{\circ} \mathrm{C}$ (Gottschalk, 1987).

If much of at least the southern half of unit 3 was originally metamorphosed under blueschist-facies conditions (as suggested by the distribution of $\mathrm{gl}$ ), then the degree of recrystallization under greenschistfacies conditions is variable, ranging from very little to almost total. Core-to-rim zoning in amphiboles from gl to ac to bar amph (Gottschalk, 1987; A.B. Till, oral commun., 1987) best records the decrease in $P$ and increase in T experienced during this episode. The latest phase of the greenschist-facies part of the metamorphic episode produced a semipenetrative cleavage defined by the presence of aligned flakes of mu and ch and by dislocations in the earlier formed foliation; this was followed by growth of largely postkinematic helicitic ab 
porphyroblasts and randomly oriented bt, partial to total replacement of early formed gt by ch, and local formation of new idioblastic and unaltered gt porphyroblasts (Gilbert and others, 1977).

\section{Low-grade rocks of the Doonerak window}

Prehnite-pumpellyite-facies rocks (unit 4) and greenschist-facies rocks (unit 5), exposed in a structural window in the Mount Doonerak area of the Endicott Mountains, were also metamorphosed, but to a much lesser degree, during the widespread metamorphic episode that affected the schist belt between Middle Jurassic and mid-Cretaceous time (Dusel-Bacon and others, 1989). Both of these units consist of metasedimentary and metavolcanic rocks of Cambrian through Silurian age, and metabasite sills of Ordovician and Devonian age; unit 5 also contains an unconformably overlying sequence of Mississippian through Triassic metacarbonate and metasedimentary rocks along its northern and northeastern border (Dillon and others, 1986).

The angular unconformity between the Mississippian rocks and the underlying Devonian and older rocks in the window has been affected locally by normal faulting in the central part (Dillon and others, 1986) and thrust faulting in the eastern part (Julian and others, 1984). Structural analysis indicates that the schistosity and deformational structures in the Ordovician through Devonian rocks correspond with those in the overlying Mississippian through Triassic rocks (Julian and others, 1984). Thus, rocks both above and below the unconformity were metamorphosed during the same metamorphic episode.

The rocks of the Doonerak window are considered to be an exposure of the basement of the northern Brooks Range and both areas are included in the North Slope terrane. Units 4 and 5 appear to have the same structures as those in the structurally overlying blueschist- and greenschist-facies rocks of unit 3 outside the window (H.G. Avé Lallemant, oral commun., 1987), suggesting that metamorphism of the basement rocks of the window probably also occurred during Middle Jurassic to mid-Cretaceous time as a result of northward overthrusting. Rocks in the eastern part of the window appear to be part of a duplex structure that formed after the earliest and most pervasive metamorphic foliation and during formation of a second generation of structures, dominated by asymmetric kink folds with northwest-dipping axial planes (Julian and others, 1984) . The anomalously low (prehnite-pumpellyite facies) metamorphic grade of the structurally lowest rocks (unit 4), together with the lack of high-P minerals in units 4 and 5, are in accordance with the structural observations of Julian and her coworkers and suggest that the rocks of the window were metamorphosed under low-T and moderate- to low-P conditions late in the metamorphic episode. They were then overthrust, probably from the south, by the more deeply buried blueschist-facies rocks.

Age and tectonic origin of metamorphism

Metamorphism of unit 3 and related units of the southern Brooks Range clearly postdates the Triassic age of the youngest protoliths and probably took place in Jurassic to mid-Cretaceous time as a result of northvergent tectonic loading. The spatial association between unit 3 and obducted oceanic rocks of the Angayucham terrane (unit 8) along the southern margin of the Brooks Range and Jurassic ultramafic and mafic rocks (Ju) in the northwestern and eastem ends of the Range has been used as evidence to suggest that the rocks of the southern Brooks Range were tectonically loaded by north-directed overthrusting of oceanic rocks of Mississippian to Jurassic age along a south-dipping subduction zone (Patton and others, 1977; Roeder and Mull, 1978; Turner and others, 1979). Prior to, and probably closely preceding, its emplacement onto the continental rocks of the schist belt, the oceanic sequence was internally imbricated, and ultramafic rocks were emplaced on top of mafic rocks, becoming the structurally highest part of the sequence (Patton and others, 1977). A Middle to Late Jurassic time for this tectonic mixing is provided by KAr ages on hb of about 172 to $154 \mathrm{Ma}$ from gt amphibolite, presumably formed during thrusting, that occurs at the base of the ultramafic sheets (Patton and others, 1977; Boak and others, 1985). Stratigraphic evidence in the western Brooks Range suggests that overthrusting of the oceanic sequence onto the continental rocks in that area began in the Middle Jurassic (Tailleur and Brosgé, 1970; Mayfield and others, 1983).

Dynamothermal metamorphism clearly had ceased by mid-Cretaceous time because Albian and Cenomanian conglomeratic rocks in the Yukon-Koyukuk basin record the uplift and progressive erosional stripping of the oceanic rocks and the underlying metamorphosed continental rocks of unit 3 (Patton, 1973; Dillon and Smiley, 1984). This timing is consistent with Early to mid-Cretaceous (120-90 Ma) K-Ar cooling ages on mica from unit 3 (Turner and others, 1979; Turner, 1984; Dillon and Smiley, 1984).

Obduction of the oceanic rocks apparently occurred in response to counterclockwise rotation and oroclinal bending of the lower plate continental rocks of the Arctic Alaska plate (including the schist belt and Doonerak window) driven by rifting in the Arctic region between Early Jurassic and Early Cretaceous time (Tailleur, 1969; Mayfield and others, 1983; Grantz and May, 1983). Collision of a Jurassic and Cretaceous intraoceanic arc terrane with the southward-facing continental margin adjacent to the Yukon-Koyukuk basin has been proposed as an additional cause of the northward obduction (Box, 1985a). 
Structural and metamorphic relations between the high-P schist belt and the structurally overlying, lower $T$ and $P$, greenschist-facies continental rocks (unit 9) and prehnite-pumpellyite-facies oceanic rocks (unit 8) to the south suggests that post- or late-metamorphic down-to-the-south low-angle extensional faulting has dismembered the upper plate, removing much of the section that originally buried the blueschists. This late extensional phase of the orogeny has been postulated by several workers on the basis of map patterns (Carlson, 1985; Miller, 1987), field observations near Wiseman (Gottschalk and Oldow, 1988), and field and kinematic data from unit 10 in the Cosmos Hills east of Ambler (Box, 1987). Additional evidence in support of late- or post-metamorphic extensional movement between upper and lower plate rocks is found in the Cosmos Hills, where the allochthonous oceanic rocks of unit 8 cut across the metamorphic mineral zones in unit 3 (Hitzman, 1984). Continuation of extensional tectonism into Late Cretaceous, and perhaps early Tertiary, time is recorded in the deformational and metamorphic history of unit 10.

Jurassic to mid-Cretaceous low-arade metamorphism of oceanic thrust sheets

Weakly metamorphosed sedimentary and volcanic oceanic rocks crop out in a narrow V-shaped belt around the margins of the Yukon-Koyukuk basin along the southern margin of the Brooks Range and the northwestern margin of the Ruby geanticline, outboard of metamorphosed continental rocks to the north and southeast, respectively. These rocks make up the Angayucham terrane and consist of an inner and structurally lowest thrust sheet of ocean-continent transition-zone (Patton and others, in press; W.W. Patton, Jr., and J.M. Murphy, oral commun., 1988) greenschist-facies metagraywacke and phyllite, with minor amounts of metalimestone and metachert, of Devonian to Triassic protolith age (unit 9); and an outer (basinward) overlying sheet of oceanic prehnite-pumpellyite-facies metabasite, metachert, metatuff, metalimestone, and argillite of Mississippian to Jurassic protolith age (unit 8). The structurally highest thrust sheet is of peridotite and gabbro (Ju).

These thrust sheets have been interpreted as components of an allochthonous oceanic complex, rooted in the Yukon-Koyukuk basin, that was thrust onto the Proterozoic and early Paleozoic continental margin during Middle Jurassic to mid-Cretaceous time causing blueschist- and greenschist-facies metamorphism in the underlying rocks in the southern Brooks Range and possibly along the western margin of the Ruby Geanticline (unit 28, discussed below in the section entitled Central Alaska) (Patton and others, 1977, in press; Turner and others, 1979; Patton and Box, 1985). Some, or all, of the prehnite-pumpellyitefacies metamorphism of unit 8 may have accompanied thrust emplacement (Hitzman, 1983; Dusel-Bacon and others, 1989) as suggested by the following observations: 1) In the Cosmos Hills, prehnite-pumpellyitefacies metamorphism is most intense adjacent to the thrust surface between unit 8 and underlying unit 3 (Hitzman, 1983). 2) In the Ruby geanticline, gl occurs locally in metabasalt of unit 8 near the base of its tectonic contact with underlying unit 28 (Patton and Moll, 1982). The occurrence of gl indicates that some of these rocks were metamorphosed under high-P, low-T conditions and may have been tectonically intermixed with other rocks of this unit, either during the intemal imbrication (emplacement of peridotite and gabbro on top of the basaltic thrust sheets) that preceded the obduction of the oceanic complex, or during the obduction itself (Patton and Moll, 1982).

The metamorphic history of unit 9 is less certain. In the Wiseman area of the southern Brooks Range, Dillon and others (1987) consider that the rocks of this unit have a single semipenetrative cleavage, in sharp contrast with the more complexly metamorphosed and deformed rocks of unit 3 to the north. However, mapping in this same sequence of rocks by Gottschalk (1987) in the Wiseman area, and Hitzman and others (1982) in the Cosmos Hills area, suggests that the rocks of this unit shared a common metamorphic history with unit 3.

\section{SEWARD PENINSULA}

Jurassic to Early Cretaceous blueschist-evolving to areenschist-facies metamomhism

High-P blueschist-facies rocks that were partly recrystallized under intermediate-P greenschist-facies conditions crop out over a large 125-by-150-km area (shown as unit 16) across the central Seward Peninsula. These rocks, referred to as the Nome Group, consist of pelitic schist, quartzite, marble, metabasite, mafic schist, and orthogneiss and are thought to have originated in a continental platform environment (Sainsbury and others, 1970; Till, 1983; Forbes and others, 1984). Protoliths of metasedimentary and metavolcanic rocks are Proterozoic and early Paleozoic (largely Ordovician) in age, and crosscutting orthogneiss has a Devonian intrusive age (Till and others, 1986; Armstrong and others, 1986).

Metamorphic minerals in the metabasite are gl, ep, gt, ab, sp, ac, ch, wm; pseudomorphs of ep, pa, and locally ab occur after Iw (Forbes and others, 1984; Thurston, 1985). Glaucophane is also present in pelitic and mafic schist, and impure marble. Glaucophane-bearing eclogitic rocks have been found just east of the Nome River (Thurston, 1985). Local stabilization of eclogitic rocks is attributed to either outcrop-scale 
metamorphic conditions marginally different (perhaps lower $\mathrm{P}_{2} \mathrm{O}$ ) from those in the surrounding rocks (Thurston, 1985), or to small but complex variations in bulk composition (Evans and others, 1987).

Petrographic, structural, and phase-equilibrium data indicate that crystallization of the blueschist- and greenschist-facies assemblages occurred during a single episode of high- evolving to intermediate-P, low-T metamorphism, similar to that recorded in the schist belt of the southern Brooks Range. Metamorphic conditions during the high-P phase of this monocyclic polyfacial episode started in the gl-lw-jdpx stability field and, with increasing T, evolved into the ep-gt-gl stability field (Thurston, 1985). The P-T path passed through approximately 9 to $11 \mathrm{~kb}$ at 400 to $450^{\circ} \mathrm{C}$ during the highest $P$ phase of the prograde episode and passed into the ab-ep-bar amph field during initial stages of decompression and thermal relaxation (Forbes and others, 1984). Static retrograde alteration under greenschist-facies conditions occurred during subsequent rapid uplift. The final stages of this metamorphic episode are inferred to have taken place under intermediate$P$ conditions, because subsequent Cretaceous amphibolite-facies metamorphism (of unit 18), discussed below, that overprints the blueschist-facies fabric began in the ky stability field.

Metamorphism was synkinematic with penetrative ductile deformation, mesoscopic intrafolial isoclinal folding, and development of flat-lying to gently dipping transposition foliation (Thurston, 1985). Stretching lineations and isoclinal fold axes have a north-south trend (Till and others, 1986). The ubiquitous parallelism between stretching lineations and fold axes suggests a highly noncoaxial deformation during which fold axes rotated toward the stretching direction, as noted by Patrick (1986). Quartz petrofabrics indicate northward vergence during deformation (Patrick, 1986).

\section{Cretaceous amphibolite- and aranulite-facies metamorphism}

Amphibolite-facies pelitic, calcareous, and quartzofeldspathic schist, marble, quartzite, and amphibolite (unit 18) crop out within the Kigluaik, Bendeleben, and Darby Mountains of the southern Seward Peninsula. Protoliths probably include upgraded lithologic equivalents of the Nome Group--the same protoliths as those of unit 16 (Till and others, 1986). Intermediate-P conditions are indicated by the assemblage ky-st-sil in pelitic schist; T conditions range from those of the bt zone to the silt+kf zone.

On the south flank of the Kigluaik Mountains, isograds that define a northward-increasing prograde metamorphic sequence are closely spaced (Till, 1980; Thurston, 1985), indicating a fairly steep geothermal gradient within the ky stability field. Thurston (1985) proposed that, in this area, the intermediate-P amphibolite-facies minerals were statically superimposed on pelitic rocks whose foliation developed during the widespread Jurassic blueschist-facies metamorphic episode (of unit 16) and that the ky-bearing assemblages were produced during intermediate-P thermal metamorphism associated with Cretaceous plutonism. Work by Patrick and Lieberman (1987) also indicates structural and metamorphic continuity across the contact between units 16 and 18 and supports the hypothesis that the amphibolite-facies assemblages (as well as granulite-facies assemblages, discussed below) were superimposed on (and mostly obliterated) the earlier formed blueschist-facies assemblages.

In the Bendeleben and Darby Mountains, amphibolite-facies metamorphism was more dynamothermal in character and produced ky-bearing assemblages that define a penetrative fabric. These assemblages are overprinted by static, low-P, high-T assemblages that apparently formed as a result of thermal metamorphism associated with Late Cretaceous ( $80 \mathrm{Ma}$ ) plutonism (Till and others, 1986).

In one area of the Kigluaik Mountains, high-T rocks, whose metamorphism is inferred to have been associated with the thermal episode that culminated in the intrusion of 80 -Ma plutons (A.B. Till, oral commun., 1987), form an area large enough to show as a separate unit (unit 19). This unit consists of upper amphibolite-facies bt gneiss; granulite-facies marble, pelitic, quartzofeldspathic, and mafic gneiss, and migmatite; and gt Iherzolite partially recrystallized to sp Iherzolite (Till, 1980, 1983). Protoliths are assumed to include upgraded lithologic equivalents of the Nome Group (Till and others, 1986). Relict ky inclusions within gt formed during granulite-facies metamorphism indicate that granulite-facies metamorphism post-dated the intermediate-P amphibolite-facies metamorphism (A.B. Till, oral commun., 1987).

Age and tectonic origin of blueschist- greenschist-amphibolite-. and aranulite-facies metamorphism

Blueschist-facies metamorphism was apparently caused by rapid tectonic loading of a continental plate (Forbes and others, 1984). Rb-Sr whole-rock-mica isochron ages and K-Ar mineral ages suggest that the high-P metamorphic cycle took place during the Middle or Late Jurassic, before about $160 \mathrm{Ma}$, followed by decompression and partial re-equilibration between about 160 and $100 \mathrm{Ma}$ (Armstrong and others, 1986). Similarities in protoliths, metamorphic grade, structural style, and apparent metamorphic age suggest a correlation between the high-P, low-T metamorphic and tectonic history of unit 16 and the schist belt of the southern Brooks Range (Armstrong and others, 1986; Patrick, 1986; Dusel-Bacon and others, 1989). By analogy with the proposed history of the schist belt, multiple thrust sheets of oceanic rocks (Angayucham terrane) may have once covered the Seward Peninsula (Till, 1983; Forbes and others, 1984). The nearest possible remnant of that oceanic terrane is a sliver of north-south-trending blueschist-facies rocks (unit 17, 
discussed below) that crops out on the eastern Seward Peninsula; other possible remnants have been proposed by Box (1985a).

A major difference in the subsequent metamorphic histories of the two areas, however, is the subsequent occurrence of moderate- to high-T metamorphism and plutonism on the Seward Peninsula and the absence of these thermal episodes in the schist belt. The rapid change from blueschist metamorphism to intermediate-P amphibolite-facies metamorphism and plutonism is similar to that described in the southern Aegean by Lister and others (1984). Intermediate-P metamorphism in the Aegean was synkinematic with extensional deformation. It was probably driven by gravitational spreading, following the compressional (blueschist) phase of tectonism. An alternative comparison is made by Patrick and Lieberman (1987) who compare the sequence of metamorphic and plutonic episodes on the Seward Peninsula to that observed in the Central Alps. They attribute the thermal overprinting to relaxation of isotherms following subduction, leading to the onset of crustal anatexis. Because no evidence of extensional faulting has been identified on the Seward Peninsula, the tectonic history of the Central Alps appears to be a better analog than does that of the southern Aegean.

The environment of crystallization of the gt Iherzolite of unit 19 is unknown. Textural relations indicate that gt was stable in the Iherzolite prior to granulite-facies metamorphism, during which time the sp-bearing assemblages apparently formed (Till, 1980; Lieberman and Till, 1987). The gt-bearing assemblage may be a relict of an upper mantle environment or may have been metamorphosed in a deep crustal setting. In the latter case, formation of the gt either occurred during a pre-Mesozoic event, or during the early phases of the Jurassic and Cretaceous metamorphic episode of the schist belt and Seward Peninsula, simultaneous with formation (at shallower levels) of the extensive blueschist-facies terranes (Lieberman and Till, 1987).

\section{Probable Jurassic to Early Cretaceous blueschist-facies metamorphism}

Blueschist-facies mylonitic metabasite and minor amounts of serpentinite crop out in a narrow faultbounded belt (unit 17) along the east side of the Darby Mountains (Till and others, 1986). Protoliths are considered to range in age from middle Paleozoic to Jurassic on the basis of a tentative correlation with the low-grade oceanic rocks of the Angayucham terrane (unit 8) that are present around the margins of the Yukon-Koyukuk basin. Mylonitic metabasite in the northern part of the belt contains the assemblage cr-lw-pu, which is indicative of the low-T subdivision of the blueschist facies; mylonitic metabasite in the southern part of the belt contains the assemblage cr-ep-ac, indicative of the high-T (epidote-bearing) subdivision of the blueschist facies (subdivisions those of Taylor and Coleman (1968) and Evans and Brown (1987)). Relict igneous pyroxene grains are common in mylonitic metabasite in both areas (Till, 1983). The presence of $\mathrm{cr}$ and $\mathrm{Iw}$ in this unit indicates that pressures probably occurred within the lower part of the range of $P$ conditions in the nearby and more extensive unit 16. Somewhat different crystallization and deformational histories for the two units are indicated, however, by the incomplete recrystallization and brittle deformation of this unit compared with the complete recrystallization and ductile deformation of unit 16 (Till and others, 1986).

A Middle Jurassic to mid-Cretaceous metamorphic age is assigned to unit 17 on the basis of correlation of its metamorphic history with that of the Angayuchum terrane. Arguing against this correlation is the widespread development of high-P minerals in unit 17 and the general absence of high-P minerals in the Angayucham terrane.

\section{CENTRAL ALASKA}

\section{Pre-middle Paleozoic greenschist- and amphibolite-facies metamorphism}

Metamorphic units 22 and 23 crop out southeast of the Susulatna fault and were metamorphosed sometime during Proterozoic to middle Paleozoic time. The more extensive unit (22) consists of greenschistfacies Late Proterozoic felsic metavolcanic rocks (Dillon and others, 1985) and pre-Ordovician schist, quartzite, phyllite, argillite, marble, and mafic metavolcanic rocks (Silberman and others, 1979; Patton and others, 1980). Metamorphic grade is mostly of the ch and bt zones, but locally reaches the gt zone. PreOrdovician metamorphic, as well as protolith, ages are indicated for this unit because it is overlain by virtually unmetamorphosed Ordovician through Devonian strata that yield conodont-alteration indices that correspond with very low temperatures--generally less than $200^{\circ} \mathrm{C}$ (A.G. Harris, written commun., 1984). A minimum metamorphic age of $514 \mathrm{Ma}$ is provided by the oldest of three K-Ar ages on mica from qz-mu-ch schist within this unit (Silberman and others, 1979). K-Ar and U-Pb data suggest that these rocks were not affected by the Late Jurassic and (or) Early Cretaceous metamorphic episode that occurred northwest of the Susulatna fault in the Ruby geanticline (Dillon and others, 1985).

The other pre-middle Paleozoic metamorphic unit (23) is limited in area. It consists of polymetamorphosed and locally mylonitic pre-Ordovician schist, sheared grit, quartzite, phyllite, mafic and felsic metavolcanic rocks, and schistose metaplutonic rocks (Dusel-Bacon and others, 1989). Metaigneous rocks give Middle Proterozoic protolith ages (Silberman and others, 1979; Dillon and others, 1985). 
Polymetamorphism is suggested by replacement textures in pelitic rocks. The $M_{1}$ episode (or alternatively, the maximum-T phase of a P-T loop) occurred under amphibolite-facies conditions and produced the assemblage bt+gt+st+co in qz-mica schist. Subsequent retrograde metamorphism $\left(M_{2}\right.$, or alternatively, a late phase of $M_{1}$ ) resulted in the almost complete replacement of st by ctd, gt by $c h$, and co by wm and ch. Textural evidence suggests that retrogressive greenschist-facies metamorphism was accompanied by shearing (Dusel-Bacon and others, 1989).

A maximum metamorphic age for both postulated metamorphic episodes is indicated by the Middle Proterozoic protolith ages; a middle Paleozoic minimum metamorphic age for the episodes is tentatively provided by the U-Pb lower intercept age on zircon $(390 \pm 40 \mathrm{Ma}$ ) from the metavolcanic rocks (Dillon and others, 1985) and by the virtually unmetamorphosed overlying Ordovician through Devonian strata. A Late Proterozoic ( $663 \mathrm{Ma}$ ) K-Ar age on mu from recrystallized mylonite along the border of metaquartz diorite (Silberman and others, 1979) may date the time of uplift and cooling, following retrogressive metamorphism of the country rocks and metamorphism and shearing of the plutonic body.

\section{Pre-Early Cretaceous areenschist- and amphibolite-facies metamorphism}

Pre-Early Cretaceous metamorphism affected four monometamorphic units $(24,25,28,30)$ and two polymetamorphic units $(26,27)$ in or near the Ruby geanticline. All of the units are considered to be part of the Ruby terrane and contain continental sedimentary, volcanic, and plutonic protoliths of Proterozoic and (or) Paleozoic age. Intermediate- to high-P metamorphism of unit 28 , discussed in a later section, is interpreted (Dusel-Bacon and others, 1989) to have taken place during the Mesozoic obduction of oceanic thrust sheets onto the continental margin. Timing of metamorphism(s) in the other units is more uncertain, and in most areas is known only to predate the intrusion of regionally extensive plutons that have yielded Early Cretaceous (about $110 \mathrm{Ma}$ ) K-Ar ages (Silberman and others, 1979; Patton and others, 1987).

Little is known about the metamorphic history of monometamorphic greenschist-and epidoteamphibolite-facies unit 24 and the higher grade areas of amphibolite-facies rocks (unit 25) within it. In the northeastern exposure of unit 25 , some of the amphibolite-facies minerals may have been produced by thermal metamorphism caused by the adjacent Early Cretaceous plutons. In the southwestern exposure of unit 25, however, foliation of the amphibolite-facies rocks trends northwestward, subperpendicular to regional trends of thrust fault traces and plutons; metamorphism in this area clearly predates, and is unrelated to, the intrusion of Cretaceous or early Tertiary plutons, most of which are too small to be shown on sheet 1 (G.M. Smith, written commun., 1986).

The third monometamorphic unit $(30)$ consists of lower amphibolite-facies rocks that crop out in a small area north of the Iditarod-Nixon Fork fault. These rocks include amphibolite, orthogneiss, pelitic schist, and quartzite (Miller and Bundtzen, 1985) and were informally designated as the Idono sequence by Gemuts and others (1983). U-Pb data on zircon from orthogneiss indicate an Early Proterozoic age for their granitoid protolith (M.L. Miller and T.W. Stern, unpub. data, 1987). K-Ar dates on hb from amphibolites include both Middle Proterozoic (1.22 and $1.08 \mathrm{Ga}$ ) and Early Cretaceous (126 Ma) ages; K-Ar dates on bt from amphibolite are about $324 \mathrm{Ma}$ and $133 \mathrm{Ma}$ (Miller and Bundtzen, 1985; M.L. Miller, written commun., 1986).

Polydeformed and polymetamorphosed metasedimentary and metaigneous rocks (unit 26) crop out in the Ray Mountains (Dover and Miyaoka, 1985a, b). This unit consists of quartzofeldspathic paragneiss, augen gneiss (shown as a metamorphosed pluton), schist, gneiss, marble, quartzite, phyllonite, metabasite, and amphibolite. Only the protolith age of the augen gneiss (Devonian: Patton and others, 1987) is known. Dover and Miyaoka (1985a, b) proposed that the unit experienced at least three deformational episodes and two major metamorphic episodes.

$M_{1}$ occurred primarily under amphibolite-facies conditions. It was synkinematic with ductile deformation, and produced blastomylonitic fabrics that are axial planar to isoclinal folds. Isoclines produced during the $M_{1}$ episode are overprinted by a second generation of folds that have an axial planar cleavage $\left(\mathrm{S}_{2}\right)$ at a low to moderate angle to the older schistosity. $\mathrm{S}_{2}$ folds are tight and increase in abundance toward cataclastic zones in which a cataclastic foliation is the dominant fabric; this fabric appears to coincide with the $S_{2}$ cleavage. $\mathrm{S}_{2}$ structures are invariably associated with greenschist-facies minerals attributed to a retrogressive metamorphic episode $\left(\mathrm{M}_{2}\right)$. Within intensely cataclasized phyllonite zones, $\mathrm{M}_{2}$ minerals replace gt, bt, and st that were produced during $M_{1}$ metamorphism; $M_{2}$ minerals also grew synkinematically along shear surfaces. Glaucophane occurs with ctd in an $\mathrm{M}_{2}$ mineral assemblage at one locality within a phyllonite zone (Dover and Miyaoka, 1985b; sheet 1).

A similar sequence of polydeformed, polymetamorphosed, and moderately to strongly mylonitized schist, gneiss, quartzite, marble, and amphibolite, and singly metamorphosed granitoid gneiss, including augen gneiss (unit 27), crops out in the Kokrines Hills (Patton and others, 1978). The protolith age of the granitoid gneiss is unknown, but on the basis of lithologic similarity with dated augen gneiss in the Ray Mountains (unit 26) and in the southern Brooks Range (unit 2), a Devonian age is likely. I propose a tentative polymetamorphic history for this unit on the basis of the following field observations and interpretations made 
by J.T. Dillon (written commun., 1983): (1) metamorphic foliation $\left(S_{1}\right)$ in quartzite and associated schist and gneiss is truncated by the granitoid gneiss whose foliation $\left(S_{2}\right)$ is approximately perpendicular to the intrusive contact and locally to $S_{1} ;(2) S_{1}$ foliation formed during an earlier metamorphic episode $\left(M_{1}\right)$, and $S_{2}$ foliation and cleavage formed during a later metamorphic episode $\left(M_{2}\right)$; and $(3) M_{1}$ produced bt, gt, sil, and locally ky and $\mathbf{k f}$ in pelitic rocks, and $\mathrm{M}_{2}$ produced $\mathrm{gt}, \mathrm{mu}$, and bt in granitoid gneiss. Broad structural relations suggest that this unit may form an east-northeast-trending gneiss dome (Patton and others, 1978), but the age and origin of doming or remobilization are unknown.

\section{Age and tectonic origin of pre-Early Cretaceous metamorphic episodes}

Proterozoic and (or) Paleozoic metamorphism may have occurred in several of the areas. The Idono sequence (unit 30 ) yields both Middle Proterozoic and Early Cretaceous mineral ages, which may indicate a correlation between its metamorphic history and that proposed for polymetamorphic unit 31 in southwestem Alaska. As discussed in a later section, metamorphism of unit 31 apparently took place during both Early Proterozoic and Jurassic to Cretaceous time. Amphibolite-facies metamorphism ( $M_{1}$ of unit 27$)$ in the Kokrines Hills may have predated the probable Devonian intrusive age of granitic gneiss, whose presumed metamorphic fabric is reported to crosscut the $S_{1}$ fabric of the rest of the unit. Similar orthogneiss, forming the structurally lowest thrust sheets in the Ray Mountains, may also have experienced a pre- or syn-Devonian metamorphic episode $\left(M_{1}\right.$ of unit 26).

Obduction of mafic-ultramafic oceanic rocks onto the Proterozoic and middle Paleozoic continental margin (area of the southem Brooks Range and Ruby geanticline) during Middle Jurassic to mid-Cretaceous time is the most likely cause of the greenschist- and epidote-amphibolite-facies metamorphism of unit 24, and the greenschist-facies $M_{2}$ metamorphism of unit 26. The occurrence of $\mathrm{gl}$ in an $\mathrm{M}_{2}$ retrogressive greenschistfacies assemblage, and the increased development of cataclastic fabrics and retrogressive metamorphism in shear zones in the Ray Mountains (unit 26), supports the overthrust origin proposed above. This tectonic model is the same one that is more clearly indicated for unit 28 (discussed below).

\section{Mesozojc low-arade locally high-P. metamorphism}

Greenschist-facies continental rocks (unit 28) and prehnite-pumpellyite-facies oceanic rocks (unit 29) were metamorphosed during an Early Cretaceous or older Mesozoic episode that occurred locally under high-P (blueschist-facies) conditions. These units are exposed within and east of both the Kokrines Hills and the Kaiyuh Mountains. The units in both areas are correlative and have been offset by approximately $160 \mathrm{~km}$ of right-lateral movement along the Kaltag fault (Patton and others, 1984). The greenschist-facies rocks (unit 28) make up a basement assemblage that consists of schist, quartzite, phyllite, slate, and mafic metavolcanic rocks of Proterozoic(?) and Paleozoic age and recrystallized limestone, dolomite, and chert of early to middle Paleozoic age. This unit is defined by the local presence of $g l$ in pelitic schist $(+w m+q z+g t+c h \pm c t d)$ and metabasite $(+c h+a b+e p \pm a c)$. It, like the similar undifferentiated greenschist-and epidote-amphibolite-facies unit (24) that is devoid of gl, is included in the Ruby terrane.

The prehnite-pumpellyite-facies oceanic rocks (unit 29) occur as large thrust sheets (Patton and others, 1977) composed of metabasite, metachert, metasedimentary rocks, metalimestone, and metatuff. Protoliths range in age from Late Devonian to Late Triassic. The northwesternmost thrust sheets are included in the Tozitna terrane and the southeasternmost thrust sheets in the Innoko terrane. The degree of low-T metamorphism varies considerably within the unit and appears to be a function of the structural position within the thrust sheet (W.W. Patton, Jr., and S.E. Box, oral commun., 1985). Glaucophane occurs locally in metabasite near the structural base of the Tozitna terrane (Patton and Moll, 1982) where localized higher $P$ conditions may have existed.

The intermediate- to locally high-P metamorphism of units 28 and 29 presumably resulted from tectonic loading accompanying the obduction of thrust sheets of oceanic rocks onto the Proterozoic and early Paleozoic continental margin. The primary evidence for this model is the occurrence of $\mathrm{gl}$ at the base of the oceanic thrust sheets (the northwestern exposures of unit 29, assigned to the Tozitna terrane, and unit 8 , assigned to the Angayucham terrane and discussed previously), as well as in the underlying continental greenschist-facies rocks of unit 29. Patton and others (in press) present stratigraphic evidence that the obducted oceanic thrust sheets assigned by Jones and others (1987) to the Tozitna and the Angayucham terranes are parts of a single terrane.

The direction from which these oceanic terranes were thrust and, therefore, correlation of their metamorphic histories is a matter of some debate. According to one hypothesis (discussed earlier), the thrust sheets of a (composite) Angayucham-Tozitna terrane were rooted in the Yukon-Koyukuk basin and thrust southeastward over the continentally derived rocks of the Ruby geanticline (Patton and others, 1977, in press; Patton and Moll, 1982; Turner, 1984). According to an alternative hypothesis, based on structural analysis of S-C fabrics (non-coaxial schisocity and shear surfaces) and the sense of rotation of large-scale 
nappe-like folds (Miyaoka and Dover, 1985; Smith and Puchner, 1985; G.M. Smith, written commun., 1986), the Tozitna terrane was thrust in the opposite direction--from the southeast toward the northwest. Dover and Miyaoka (1985b) attribute the development of cataclastic fabrics and accompanying retrogressive metamorphism within a part of the lower plate rocks $\left(\mathrm{M}_{2}\right.$ of unit 26$)$ to the northwestward obduction of the Tozitna terrane that lies to the south.

Middle Jurassic and mid-Cretaceous maximum and minimum metamorphic age constraints for metamorphism caused by southeastward thrusting out of the Yukon-Koyukuk basin are discussed in the Brooks Range section. Metamorphism, if caused by northwestward obduction of the Tozitna terrane, would have to postdate the Triassic age of the youngest protoliths of that terrane. Metamorphism of units 28 and 29, prior to late Early Cretaceous time, is also indicated by K-Ar ages of 134 and $136 \mathrm{Ma}$ on metamorphic mu from gl-bearing schist (unit 28) in the Kaiyuh Mountains (Patton and others, 1984), and by the 111-Ma age of a granitoid pluton that intrudes both the Ruby and Angayucham terranes in the Kokrines Hills (Patton and others, 1977, 1978).

\section{SOUTHWESTERN ALASKA}

\section{Early Proterozoic amphibolite-facies metamorphism}

The oldest dated metamorphic episode in Alaska is recorded in a narrow, northeast-trending, faultbounded belt of continentally derived amphibolite-facies rocks east of Kuskokwim Bay. These rocks, shown as unit 31, form the antiformal (informal) Kanektok metamorphic complex of the Kilbuck terrane and are composed of bt+hb+gttcpx gneiss, gt-mica schist, orthogneiss, gt amphibolite, and rare marble (Hoare and Coonrad, 1979; Turner and others, 1983). Kyanite, indicative of intermediate- to high-P conditions, occurs in gt-mica schist at one locality. Protoliths are Early Proterozoic sedimentary, mafic volcanic, and granitic rocks (Turner and others, 1983). Metamorphic mineral grains generally define a strong lineation and a foliation that is parallel to compositional layering. All of these structural features strike consistently to the northeast, roughly parallel to the trend of the complex (Hoare and Coonrad, 1979; D.L. Turner, written commun., 1982). On the basis of aeromagnetic, gravity, and field data, the structural setting of this metamorphic complex (Kilbuck terrane) has been interpreted as a rootless subhorizontal klippe (Hoare and Coonrad, 1979) or, alternatively, as a block extending to an unknown depth between two southeast-dipping thrust faults (Box, 1985c).

A 1.77-Ga (Early Proterozoic) metamorphic age for amphibolite-facies metamorphism is indicated by a U$\mathrm{Pb}$ age on sph from orthogneiss, by the oldest of five Proterozoic K-Ar hb ages from amphibolite, and possibly also by a whole-rock Rb-Sr "isochron" (Turner and others, 1983). A minimum age for this metamorphic episode is provided by a $1.2-\mathrm{Ga}$ age from ${ }^{40} \mathrm{Ar} /{ }^{39} \mathrm{Ar}$ incremental heating studies on hb from gt amphibolite (Turner and others, 1983).

On the basis of isotopic data, subsequent greenschist-facies retrogressive metamorphism $\left(M_{2}\right)$ is proposed to have affected the amphibolite-facies rocks during Late Jurassic to Early Cretaceous time. Nearly all of the 58 dated rocks collected throughout the metamorphic complex show a total or partial resetting of K$\mathrm{Ar} \mathrm{hb}$ and bt ages and fall in the range of 150 to $120 \mathrm{Ma}$ (D.L. Tumer, written commun., 1982; Turner and others, 1983). Because only a limited and cursory petrographic study of the the amphibolite-facies rocks has been made, it is not known to what degree, and under what $T$ and $P$ conditions, recrystallization accompanied the Mesozoic thermal episode that is documented by the isotopic dating. A latest Early Cretaceous minimum age for $\mathrm{M}_{2}$ is indicated because: (1) overlying unmetamorphosed Albian conglomerates contain Kanektok components, and (2) unmetamorphosed Valanginian sediments to the south contain metamorphic gt and ep thought to be derived from the metamorphic complex (Murphy, 1987).

Unit 31 is similar in its lithology, internal structure, structural relation to adjacent mafic complexes, and Mesozoic K-Ar ages to the metamorphic belt that occurs along the southeastern borderland of the YukonKoyukuk basin to the north (Ruby terrane) discussed in the previous section (Box, 1985a). The part of this belt closest to unit 31 is the informally designated Idono sequence (unit 30 ) $250 \mathrm{~km}$ to the northeast (Miller and Bundtzen, 1985)--a sequence which also gives Proterozoic and Early Cretaceous metamorphic-mineral ages. Several linear northeast-trending faults separate the two metamorphic units. One of these, the Iditarod-Nixon Fork fault, shows evidence of about $110 \mathrm{~km}$ of post-Cretaceous right-lateral offset (Grantz, 1966). If the other faults show similar senses of displacement, units 30 and 31 may prove to be right-lateral offset equivalents, making both part of the Ruby terrane (Dusel-Bacon, Doyle, and Box, in press).

\section{Low-grade, locally high-P. Mesozoic metamorphism of oceanic rocks}

The predominant period of metamorphism in southwestern Alaska occurred under low-grade conditions during Mesozoic time. Most of the rocks that were metamorphosed are of oceanic affinity; the continentally derived Early Proterozoic metamorphic rocks of unit 31 apparently were retrograded during the Mesozoic. 
Blueschist-facies rocks occur in two areas (units 33,34 ) of the low-grade rocks, suggesting a subductionrelated origin for most of the low-grade metamorphism.

One of the areas of blueschist-facies rocks (unit 33) is part of a nappe complex of predominantly schistose metavolcanic and metasedimentary rocks; other rocks in the nappe complex were metamorphosed under pumpellyite-actinolite-facies (facies terminology of Turner, 1981) to greenschist-facies conditions (unit 32). Protoliths are thought to be of Permian and Late Triassic age (Box, 1985b). Recrystallization is generally incomplete and primary textures and minerals are partly preserved. Diagnostic high-P minerals $\mathrm{gl}$ (+ep+actpu) and Iw are sparse and poorly developed in unit 33 (Box, 1985b).

Metamorphism of units 32 and 33 is bracketed between the Late Triassic age of the youngest protolith and the Middle Jurassic age of postmetamorphic mafic and ultramafic plutons (Hoare and Coonrad, 1978). A 231 $\pm 7-\mathrm{Ma} \mathrm{K}$-Ar age on amph (Box, 1985b) from schist of blueschist-facies unit 33 suggests that metamorphism of the nappe complex may have begun during Late Triassic time.

The other area of greenschist- and locally blueschist-facies rocks, shown as unit 34, consists of mafic schist interlayered with metachert, metalimestone, phyllite, and minor amounts of quartzose and calcareous schist (Hoare and Coonrad, 1959). Protolith ages are unknown, but limestone is probably Ordovician, Devonian, or Permian in age and chert may be as young as latest Jurassic (Tithonian) (Box, 1985b). Rocks of this unit have been affected by post-metamorphic, northwest-vergent imbrication (Box, 1985c). Greenschistfacies mafic schist is characterized by ch, ep, and ac, and blueschist-facies mafic schist by gl, ch, ac, and ep.

Actinolite from mafic schist of the northemmost exposure of unit 34 gives a K-Ar age of 146 $\pm 15 \mathrm{Ma}$ (Box and Murphy, 1987), suggesting a Late Jurassic or Early Cretaceous minimum metamorphic age. The Triassic maximum age of metamorphism of units 32 and 33 is tentatively considered to apply also to unit 34 .

The most extensive low-grade metamorphic unit (35) forms a diverse assemblage of prehnitepumpellyite-facies metabasalt, metagabbro, metavolcaniclastic and metasedimentary rocks, metachert, and metalimestone. Protolith ages range from early or middle Paleozoic to Cretaceous (Jones and others, 1987; Dusel-Bacon, Doyle, and Box, in press). Primary igneous or depositional fabrics are generally well preserved, but locally the rocks are slaty, schistose, or highly sheared and disrupted. The lack of structural fabric, the disrupted character, and the very low grade of this unit make it difficult both to determine which rocks have been metamorphosed and to assess the relation between the timing of metamorphism and the intrusion of crosscutting igneous bodies. A pre-Early Cretaceous age of metamorphism is inferred for all areas of unit 35 because unmetamorphosed Valanginian andesitic volcanic rocks unconformably overlie the northernmost exposure of this unit (Patton and Moll, 1985), and unmetamorphosed Valanginian sedimentary rocks in the southern exposure of the unit contain pr-pu-bearing metavolcanic clasts (Murphy, 1987).

Mesozoic metamorphism is attributed to progressive underthrusting of a composite subduction complex (Goodnews terrane) beneath the northwestern margin of an oceanic arc (Togiak terrane), followed by underthrusting of the Early Proterozoic continental metamorphic complex (Kilbuck terrane) beneath the northwestem margin of Goodnews terrane (fig. 3) (Box, 1985b, c).

According to this tectonic model, metamorphism of blueschist- and greenschist-facies units 33 and 32 , respectively, occurred during the first episode of underthrusting. These two units make up the Cape Peirce subterrane of the Goodnews terrane of Box (1985b, c). Box believes this subterrane structurally underlies the prehnite-pumpellyite-facies rocks of the Togiak terrane and overlies the prehnite-pumpellyite-facies rocks of the Platinum subterrane of the Goodnews terrane (terranes and subterranes are those of Box, 1985c) along low-angle southeast-dipping faults (fig. 3). Both areas of prehnite-pumpellyite-facies rocks are included in unit 35. Metamorphism of the Cape Peirce subterrane is presumed to have occurred during collision and partial subduction of an oceanic plateau (Platinum subterrane of the Goodnews terrane) beneath an overriding intraoceanic subduction-related volcanic arc (Togiak terrane). Lithologic similarities between the protoliths of the schistose blueschist- and greenschist-facies rocks of the Cape Peirce subterrane and those of the relatively undeformed low-grade overlying and underlying subterranes, suggest that the rocks of the Cape Peirce subterrane are the more tectonized equivalents of the adjacent two subterranes (Box, 1985b). Mafic and ultramafic plutons that intrude the Cape Peirce subterrane, the overlying Togiak terrane, and the underlying Platinum subterrane, provide a Middle Jurassic minimum age for amalgamation of the three subterranes.

Structural data suggest that the overriding arc of the Togiak terrane was originally thrust to the northnortheast over the Goodnews terrane (Box, 1985b). However, the low-angle fault mapped between the upper plate Togiak terrane and the underlying Cape Peirce terrane juxtaposes lower $T$ and $P$ rocks over higher $T$ and $P$ rocks, suggesting that the fault is a low-angle normal fault rather than a thrust fault (Box, 1985b). As suggested by Box, a good explanation for the present relation between the plates is that early north-northeastward compressional faulting was followed by extensional (detachment) faulting. This same fault relation (lower grade rocks above higher grade rocks) occurs in the southern Brooks Range and Ruby geanticline (sheet 1); faulting in all these areas may have the same origin (extensional reactivation of earlier compressional structures). 


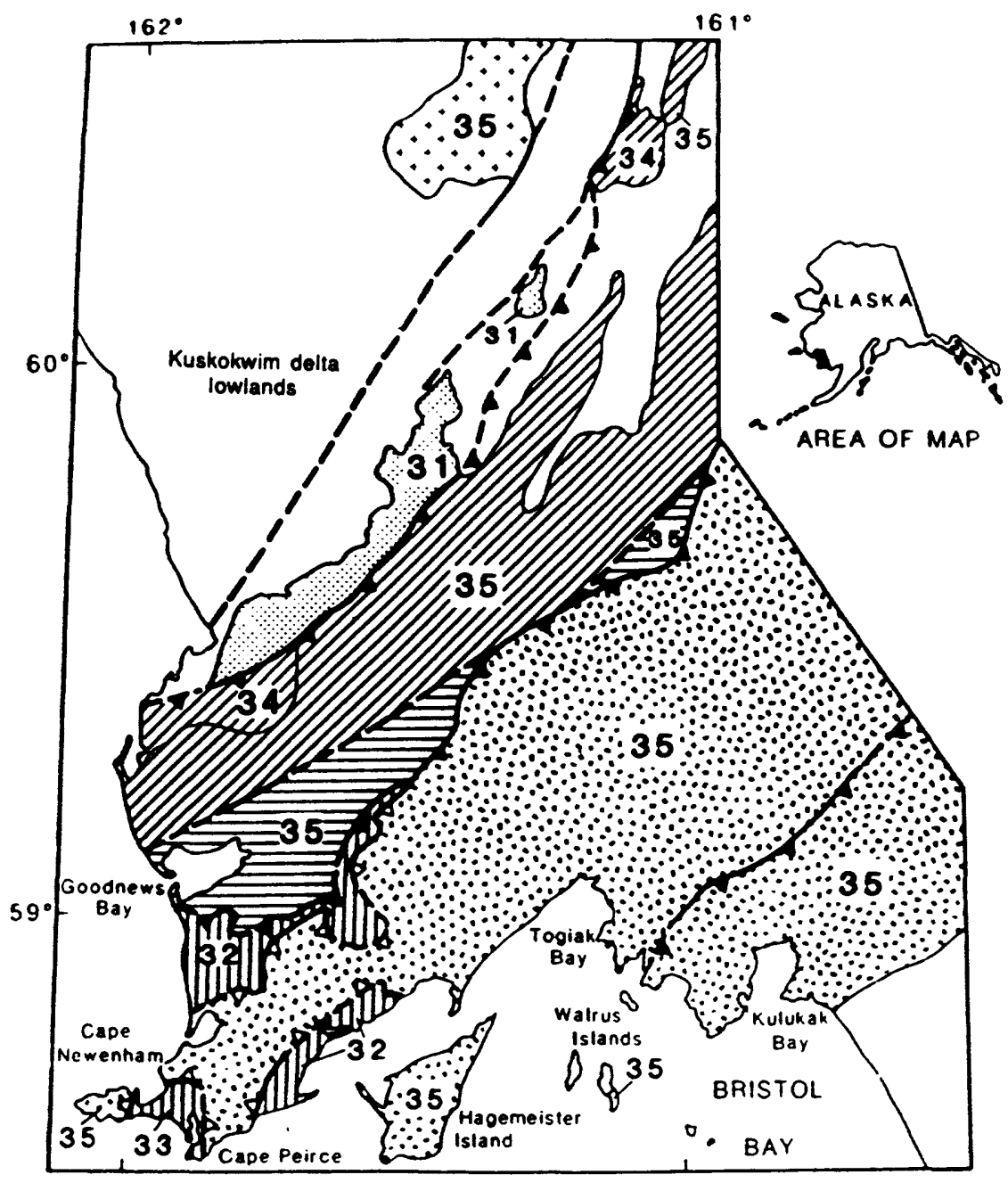

\section{EXPLANATION}

Metamorphic-facies units used in this report. Metamorphic ages in parentheses; numbers refer to symbols used on sheets 1 and 2

$\begin{aligned} 31 & \operatorname{AMP}(X)+\operatorname{GNS}(\mathrm{KJ}) \\ 32 & \operatorname{GNS}(J \hbar) \\ 33 & \operatorname{GNH}(J \hbar) \\ 34 & \operatorname{GNI}, H(K \bar{k}) \\ 35 & \operatorname{LPP}(\mathrm{pK})\end{aligned}$

Line symbols

\section{Contact or boundary between metamorphic-facies} units; dashed where approximately located

High-angle fault; dashed where approximately located

A____ Thrust fault; dashed where approximately located; sawteeth on upper plate

ــ__ Low-angle normal fault; dashed where approximately located; sawteeth on upper plate
Lithotectonic terranes

$\therefore$ Togiak terrane

Goodnews terrane

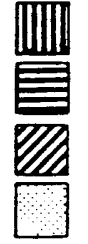

Cape Peirce subterrane

Platinum subterrane

Nukluk subterrane

Kilbuck terrane

Nyac terrane

Post-accretion cover deposits 
The greenschist- and blueschist-facies rocks of unit 34 were probably metamorphosed during the second episode of underthrusting. These rocks crop out along the northwestern margin of the Nukluk subterrane of the Goodnews terrane of Box (1985c). Late Jurassic to Early Cretaceous metamorphism of unit 34 , and retrograde metamorphism of unit 31, probably took place as the continental Kilbuck terrane (unit 31) was partially thrust beneath the accretionary forearc (Goodnews terrane) of an intraoceanic volcanic arc (Togiak terrane) (Box, 1985c). The following evidence supports this interpretation of the metamorphic history: (1) unit 34 occurs along the tectonic boundary between the Kilbuck and Goodnews terranes, and 2) the K-Ar age on ac from unit 34 falls in the same range as the Mesozoic K-Ar ages from the Kilbuck terrane.

\section{YUKON-TANANA UPLAND AND ALASKA RANGE NORTH OF THE MCKINLEY AND DENALI FAULTS}

\section{Overview}

The age and origin of metamorphism of many of the units in the Yukon-Tanana upland and northern Alaska Range are poorly known. Metamorphism throughout the Yukon-Tanana upland predates the widespread intrusion of undeformed mid-Cretaceous granitoids. Mylonitic and blastomylonitic textures are common in most rocks, reflecting a history of dynamic metamorphism, followed by varying degrees of more static recrystallization. Many metamorphic unit boundaries are also terrane or subterrane boundaries defined by low-angle faults. Metamorphic grade changes abruptly across many of the faults, indicating that major metamorphism predated final emplacement of the fault-bounded units. Some of the low-angle faults place higher grade over lower grade rocks (the relation expected of compressional faulting), whereas others place lower grade over higher grade rocks (the relation expected of extensional faulting), suggesting a complex syn- or post-metamorphic structural evolution. In their regional synthesis, Foster and her coworkers (1987) interpret the low-angle faults as being south-dipping thrusts. Thrust sheets near the Canadian border were emplaced in Early Jurassic time. Thrusting of other sheets may have occurred throughout a compressional episode that included crustal thickening and metamorphism in either or both Jurassic and (or) Cretaceous time. In one area, however, kinematic data indicate that the most recent movement along the low-angle fault that separates greenschist-facies unit $\mathbf{4 5}$ of the hanging wall from amphibolite-facies unit $\mathbf{4 6}$ of the footwall was extensional, and that the hangingwall moved to the east-southeast (Pavlis and others, 1988b).

\section{Early Paleozoic(?) hiah-P hiah-T metamomhism}

The oldest metamorphic episode inferred to have taken place in east-central Alaska produced eclogite and interlayered bands and lenses of mafic, calc-magnesian, quartzitic, pelitic schist, and impure marble. These rocks, shown as unit 36, are thought to be two klippen that form the upper plate of a folded thrust (Brown and Forbes, 1984; Foster and others, 1983). Protoliths are Proterozoic or early Paleozoic in age. Bulk chemistry suggests sedimentary protoliths for the eclogites of the western klippe (Swainbank and Forbes, 1975), whereas discordant contacts exhibited by eclogitic rocks in the eastern klippen suggest that they originated as mafic dikes (Laird and others, 1984).

Eclogite within the eastern klippe consists of various combinations of gt, omphacitic cpx, barroisite, phengitic mu, qz, and rutile (Laird and others, 1984). Eclogite within the western klippe consists of combinations of these minerals plus $\mathrm{gl}, \mathrm{tr}, \mathrm{ab}, \mathrm{ep}$, and $\mathrm{sph} ; \mathrm{ky}+\mathrm{st}+\mathrm{gt}$ occurs in interlayered pelitic schist (Brown and Forbes, 1986). Phase equilibria (excluding that proposed for gl) and thermobarometry suggest P-T conditions of about $15 \pm 2 \mathrm{~kb}$ and $600 \pm 25^{\circ} \mathrm{C}$ (Laird and others, 1984; Brown and Forbes, 1986). Such temperatures exceed the experimentally determined maximum stability limit of $\mathrm{gl}$ (Maresch, 1977) by about $50^{\circ} \mathrm{C}$. One explanation for this discrepancy is that the gl formed after the main phase of eclogite crystallization, as was proposed for an eclogitic block along the Tintina fault in Yukon Territory by Erdmer and Helmstaedt (1983). However, textural relations in the gl-bearing rocks of the western klippe show no evidence of such a progression, and the discrepancy is thus far unresolved.

A polymetamorphic history for this unit is suggested, because some eclogitic rocks in both klippen are overprinted by greenschist and epidote-amphibolite assemblages, which are characterized by hb, ab, ep, bt, and ch (Brown and Forbes, 1986; Foster and others, 1987).

An early Paleozoic metamorphic age for the first, and dominant, episode is tentatively suggested by a 470 $355-\mathrm{Ma} \mathrm{K}$-Ar age on amph from eclogite in the western klippe (Swainbank and Forbes, 1975). Early isoclinal, recumbent folds about a northwest-trending axis are attributed to this episode. This high- $P$, high-T metamorphism only affected this group of thrust-bounded rocks and thus predated the time of their emplacement. An Early Cretaceous age for subsequent retrograde metamorphism is proposed on the basis of 115- to 103-Ma K-Ar ages on mica that were determined for associated rocks; the development of folds about a northeast-trending axis is attributed to this metamorphic episode (Swainbank and Forbes, 1975). Early Cretaceous metamorphism, discussed below, was widespread throughout east-central Alaska. 
Mineral chemistry and the occurrence of gl indicate that the eclogites are similar to those from alpinetype orogenic environments (Group C of Coleman and others (1965)). The tectonic and metamorphic history of the eclogites may be similar to that of other isolated eclogite occurrences on strike along the Tintina fault in the Yukon Territory, as proposed by Erdmer and Helmstaedt (1983) and Brown and Forbes (1986). Eclogites in central Yukon Ternitory experienced a subduction-cycle P-T trajectory that included eclogite metamorphism, uplift through the stability field of gl, and finally greenschist-facies metamorphism (Erdmer and Helmstaedt, 1983). The present distribution and geologic position of the eclogite bodies in east-central Alaska and Yukon Territory suggest that rocks in both regions were emplaced as thrust sheets against or onto the cratonic margin of westem North America (Erdmer and Helmstaedt, 1983). However, the timing of metamorphism and tectonic emplacement of these eclogite-bearing terranes are not well enough constrained to allow more than a tentative correlation. The early Paleozoic metamorphic age suggested for the Alaskan eclogitic rocks, if valid, would argue against correlation with the Canadian eclogites, which are believed to have middle Paleozoic protoliths and to have been metamorphosed during the late Paleozoic (Erdmer and Armstrong, 1988).

\section{Late Triassic to Early Jurassic metamorrohism}

Metamorphism during this time period was part of an orogenic episode that consisted of metamorphism, plutonism, folding, and thrusting. This episode resulted from the closing of an ocean basin, represented by the weakly metamorphosed rocks of unit 38 and associated ultramafic rocks (MzPzU). Accretion of amphibolite-facies rocks of unit 37 was related to this episode (Foster and others, 1985, 1987).

The earliest phase of this orogenic episode produced intermediate-P amphibolite- and epidoteamphibolite-facies bt gneiss and schist, amphibolite, marble, quartzite, and pelitic schist of unit 37. Rocks are well foliated and multiply deformed; at least some protoliths are of Paleozoic age (Foster and others, 1985). This unit is intruded by latest Triassic to earliest Jurassic granitoids, similar to those in the Stikinia terrane of Yukon Ternitory, Canada (Tempelman-Kluit, 1976). Unit 37 is in thrust contact with adjacent rocks. It is probably part of the Stikinia terrane or a comparable, but different, part of composite terrane I of Monger and others (1982) that includes the Stikinia terrane and that was accreted to the margin of North America in Jurassic time (Foster and others, 1987).

Amphibolite-facies metamorphism of unit 37 reached its peak about $213 \pm 2 \mathrm{Ma}\left({ }^{40} \mathrm{Ar} /{ }^{39} \mathrm{Ar}\right.$ integrated plateau age on amph), followed by synmetamorphic intrusion of the Taylor Mountain batholith (shown as unit $\mathrm{JFg}$ ) at about 209 $\pm 3 \mathrm{Ma}$ (Cushing and others, 1984). Northward thrusting of the amphibolite-facies rocks and low-grade oceanic rocks (unit 38) took place during cooling and was completed by about $185 \mathrm{Ma}$ (Foster and others, 1987). The Early Cretaceous thermal event that strongly affected the adjacent augen gneiss-bearing amphibolite-facies unit 46 to the south (described below) was of only minor intensity in unit 37 , as indicated by the Early Cretaceous apparent ages of the low-temperature gas fractions in most of the ${ }^{40} \mathrm{Ar} /{ }^{39} \mathrm{Ar}$ age spectra (Foster and others, 1987).

Basalt and related oceanic protoliths of unit 38 were metamorphosed under prehnite-pumpellyite- and lower greenschist-facies conditions during the waning stages of the regional metamorphism that accompanied the closing of the ocean basin (Foster and others, 1987). This low-grade oceanic unit makes up the Seventymile terrane and consists of massive and locally pillowed greenstone, argillite, metatuff, qz-wm schist, qz-ac schist, quartzite, metalimestone, metachert, and metagraywacke. Most protolith ages are unknown, but conodonts and radiolarians of Permian age occur in weakly metamorphosed chert in the Big Delta quadrangle, and radiolarians of Mississippian age, brachiopods of Permian age, and conodonts of Triassic age occur in the northern Eagle quadrangle (Foster and others, 1987). These rocks are associated with ultramafic and gabbroic rocks. In at least one area, this package of rocks is part of a dismembered ophiolitic assemblage (Keith and others, 1981). Unit 38 consists of a number of isolated thrust remnants, which are themselves broken by internal thrust faults; metamorphic grade differs between individual thrust remnants. Glaucophane (+eptgt) occurs in one such thrust remnant in a small exposure of metabasalt just south of the Tintina fault (Keith and others, 1981; sheet 1).

An Early Jurassic age for low-grade metamorphism of unit 38 is indicated by a $201 \pm 5-\mathrm{Ma}{ }^{40} \mathrm{Ar} /{ }^{39} \mathrm{Ar}$ integrated plateau age on ac from greenstone in southeastern Eagle quadrangle (G.W. Cushing, unpub. data, 1984). Northwestward accretion of the amphibolite-facies unit resulted in thrusting of remnants of the telescoped ocean basin, including this unit and the associated ultramafic rocks, northward onto greenschistfacies unit 44 and southward onto amphibolite-facies unit 37 (Foster and others, 1987). This followed, or was synchronous with, the low-grade metamorphism. The outcrop of gl-bearing greenstone may be part of a fault sliver that was dragged to a greater depth in a subduction zone or a transpressive boundary along the convergent margin.

Metamorphism of greenschist-facies unit 39, included in the Yukon-Tanana terrane, was probably also part of the Late Triassic through Early Jurassic orogenic episode. This unit probably formed part of the continental margin north of the ocean basin onto which the previous two metamorphic units were accreted. 
Common rock types are qz-wm ( \pm ch \pm ac) schist, quartzite, phyllite, and metavolcanic rocks; protoliths are probably Paleozoic in age. Foliation is well developed, and rocks are multiply folded and commonly are lineated. This unit is correlated with the Klondike Schist of McConnell (1905) that crops out across the Canadian border (Foster and others, 1985). A Late Triassic to Early Jurassic metamorphic age is suggested by a 175 $\pm 14-M a$ K-Ar age on mu (Tempelman-Kluit and Wanless, 1975) and by a 202 $\pm 11-M a$ Rb-Sr wholerock age (Metcalfe and Clark, 1983) determined for Klondike Schist in Canada.

\section{Paleozoic or Mesozoic metamompism of uncertain age and origin}

The metamorphic ages of many units in east-central Alaska (units 40 to 45 in the Yukon-Tanana upland, and units 53 and 54, and $M_{1}$ of units 47 and 48 in the Alaska Range; sheet 2) are unknown. Metamorphic ages are bracketed between the known, or probable, Paleozoic age of the youngest protoliths and the Early to mid-Cretaceous age of widespread plutonism that postdates regional metamorphism. Scattered late Early Cretaceous K-Ar mineral and whole-rock ages on schist and a U-Pb age on monazite from orthogneiss (ages given on sheet 2) tentatively suggest an Early Cretaceous age for latest metamorphism. Unit 47 and its higher grade equivalent, unit 48, crop out south of the Tanana River and consist of metasedimentary, metavolcanic, and metaplutonic rocks of Devonian and older protolith age (Aleinikoff and Nokleberg, 1985; T.K. Bundtzen, oral commun., 1988). $M_{1}$ records greenschist-facies conditions in unit 47 but increases in intensity northward; it grades into the amphibolite-facies $M_{1}$ of unit 48 in the west (Bundtzen, 1981). $M_{1}$ metamorphism in units 47 and 48 postdates the Devonian age of the youngest known protoliths and predates the Early Cretaceous age of the episode that is thought to have caused lower greenschist-facies retrograde metamorphism $\left(M_{2}\right)$ in units 47 and 48 as well as the monometamorphism of unit 49 (discussed in a later section). In unit 48 and the western part of unit 47, Bundtzen and Turner (1979) proposed an Early Jurassic minimum age for $M_{1}$ on the basis of the oldest of four K-Ar ages $(195,144,123$, and $104 \mathrm{Ma})$ on $\mathrm{hb}$ from gt amphibolite in unit 48.

Unit 46, characterized by augen gneiss, gives Early Cretaceous ages from a number of isotopic systems and on this basis, its latest, and probably its only, metamorphism is believed to be Early Cretaceous in age. However, limited evidence from U-Pb zircon data from quartzite (Aleinikoff and others, 1984b, 1986) and sillimanite gneiss from unit 46 (Aleinikoff and others, 1984a), and from structural relations between augen gneiss and wallrocks in east-central Alaska and Yukon Territory, suggest that an earlier metamorphic episode may have accompanied the Mississippian intrusion of batholithic sheets of what is now augen gneiss (DuselBacon and Aleinikoff, 1985). These structural relations are: (1) that some areas of augen gneiss coincide with large structural and metamorphic culminations (Mortensen, 1983); and (2) that the concordant contacts of the augen gneiss bodies, and parallelism between lithologic contacts and the gently dipping regional penetrative fabric, suggest the augen gneiss bodies were intruded synkinematically into ductile crust (DuselBacon and Aleinikoff, 1985).

\section{Early Cretaceous metamorphism of augen aneiss-bearing unit}

Amphibolite-facies unit 46 is characterized by large bodies of augen gneiss that form a discontinuous belt of metamorphosed Mississippian plutons, believed to have developed beneath, or inland from, a continental magmatic arc of Late Devonian to Early Mississippian age (Dusel-Bacon and Aleinikoff, 1985). Other rock types, interpreted as having been wallrocks to the augen gneiss protolith, are amphibolite-facies qz-mica schist, bt and bt-hb gneiss, quartzite, amphibolite, sillimanite gneiss, and minor amounts of marble, calc-schist, and felsic gneiss. The Mississippian protolith age for the augen gneiss (about $340 \mathrm{Ma}$, on the basis of a U-Pb lower intercept age of zircon and a Rb-Sr whole-rock isochron; Aleinikoff and others, 1986) establishes a minimum protolith age for the adjacent wallrocks. Protoliths of some metavolcanic rocks are Devonian in age (Aleinikoff and others, 1986).

Transitional low- to intermediate-P conditions are indicated for unit 46 by the local occurrence of ky and (or) anda (sheet 1) in qz-mica ( \pm gt \pm st $t$ sil) schist. All the rocks of this unit are well foliated; commonly the foliation is multiply folded into isoclinal folds on various scales. Many rocks exhibit a well-developed stretching lineation, and most show some degree of mylonitization followed by varying degrees of recrystallization.

A $600 \mathrm{~km}^{2}$ body of sillimanite gneiss and flanking pelitic schist crops out in the western part of this unit (shown on sheet 1 by the sillimanite isograd) and has been interpreted as a gneiss dome by Dusel-Bacon and Foster (1983). Metamorphic grade increases across the pelitic schist on the flanks of the dome, where P-T conditions locally were near the $\mathrm{Al}_{2} \mathrm{SiO}_{5}$ triple point (approximately $3.8 \mathrm{~kb}$ and $500{ }^{\circ} \mathrm{C}$; Holdaway, 1971), to the gneissic core of the dome, where P-T conditions were near those of the second sillimanite isograd. Garnet-biotite geothermometry (calibration of Ferry and Spear, 1978) indicates an equilibration T of 535 to $600 \pm 30^{\circ} \mathrm{C}$ for pelitic schist north of the dome and 655 to $705 \pm 30^{\circ} \mathrm{C}$ for sillimanite gneiss in the core (DuselBacon and Foster, 1983). 
Petrographic evidence of a regional retrogressive metamorphic episode is minimal in most of this unit and consists of local, and minor, chloritization of bt and gt, sericitization of $\mathrm{pl}, \mathrm{kf}$, and $\mathrm{co}$, and the development of ac from hb. In the southwestern part of unit 46, however, Nokleberg and others (1986a) note that amphibolite-facies rocks are consistently retrograded to greenschist-facies assemblages, and that the degree of retrogression increases to the south. This retrogressive metamorphism is shown on the map as the second greenschist-facies episode in adjacent unit 47 to the south.

Metamorphism of unit 46 postdates the Mississippian intrusive age of the augen gneiss protolith and predates the intrusion of Early and mid-Cretaceous plutons (generally with 105- to 85-Ma K-Ar cooling ages; Wilson and others, 1985). A 115-Ma U-Pb age on zircon from an unmetamorphosed (late metamorphic?) pluton that intrudes the sillimanite gneiss dome (Aleinikoff and others, 1984a) provides the most reliable minimum age of metamorphism. Abundant isotopic data from the metamorphic rocks of this unit suggest that metamorphism occurred between about 135 and $115 \mathrm{Ma}$ : most conventional K-Ar mineral ages fall in the range of about 125 to $110 \mathrm{Ma}$; a $\mathrm{Rb}-\mathrm{Sr}$ mineral isochron for augen gneiss is $115 \mathrm{Ma}$; sph from augen gneiss gives a concordant $\mathrm{U}-\mathrm{Pb}$ age of $134 \mathrm{Ma}$; U-rich zircon fractions from sillimanite gneiss and quartzite show Early Cretaceous lead loss (Aleinikoff and others, 1986); and $\mathrm{hb}$ from augen gneiss gives a ${ }^{40} \mathrm{Ar} /{ }^{39} \mathrm{Ar}$ incremental heating plateau age of 119 Ma (T.M. Harrison, written commun., 1987).

\section{Early to Late Cretaceous metamorphism of other units}

Effects of Early Cretaceous metamorphism are believed to be widespread across much of east-central Alaska. The following limited isotopic data suggest an Early Cretaceous age for metamorphism in units $\mathbf{4 1}$ and 42 in the northwestern Yukon-Tanana upland: three K-Ar mica ages and one whole-rock age from greenschist-facies unit 41 range from 138 to $100 \mathrm{Ma}$ (Forbes and Weber, 1982), and monazite from orthogneiss of amphibolite-facies unit 42 gives a concordant U-Pb age of $115 \mathrm{Ma}$ (J.N. Aleinikoff, written comun., 1987). As mentioned earlier, retrograde effects on the eclogite-bearing klippen (unit 36) that overlie unit 41 are attributed to this same episode.

Farther south, in the Alaska Range, retrograde metamorphism in polymetamorphic units 47 and 48 is also interpreted as having taken place in the Early Cretaceous. In that area, $\mathrm{M}_{2}$ metamorphism occurred under ch-grade conditions; its effects are most evident where the metamorphic grade during $M_{1}$ was highest, namely in retrograded amphibolite-facies unit 48 and in the northern part of polymetamorphic greenschistfacies unit 47. $\mathrm{M}_{2}$ assemblages in unit 48 and the adjacent area of unit 47 define a weak metamorphic foliation that is axial planar to broad northeast-trending folds (Bundtzen, 1981). Characteristics of $M_{2}$ metamorphism and accompanying deformation in the other parts of unit 47 vary widely, and thus correlation of $\mathrm{M}_{2}$ episodes throughout the unit is tentative (Dusel-Bacon, Csejtey, and others, in press). A late Early Cretaceous metamorphic age for $M_{2}$ is suggested for unit 48 and the adjacent area of unit 47 by the oldest KAr mica age (100 Ma) determined for those rocks (Bundtzen and Turner, 1979). A similar late Early Cretaceous age is suggested by a 107-Ma K-Ar age on mu from phyllite of unit 47 in the central Alaska Range (Sherwood, 1979). Nokleberg and others (1986a) report that mid-Cretaceous plutons in the northern part of unit 47 in the Mt. Hayes quadrangle appear to have been weakly metamorphosed under lower greenschistfacies conditions together with their polymetamorphosed wallrocks, suggesting that metamorphism in that area continued longer, perhaps into Late Cretaceous time.

Low-grade regional metamorphism of monometamorphic unit 49 was synkinematic with the development of northeast-trending folds and has been correlated with the $M_{2}$ of adjacent units 47 and 48 (Bundtzen and Turner, 1979). Mylonitic textures are common throughout this unit and indicate a large dynamic component to the regional metamorphic episode. An Early Cretaceous age for this deformational and metamorphic episode is proposed on the basis of a whole-rock K-Ar age of 108 $\pm 3 \mathrm{Ma}$ on metafelsite (Bundtzen and Turner, 1979).

An eastward-increasing metamorphic sequence developed in Early(?) to Late Cretaceous time within units 50 (at least in that part east of longitude $151^{\circ}$ ), 51 , and 52--units that are bounded to the south by the McKinley fault. Low- to intermediate- $P$ conditions are indicated for the amphibolite-facies part of the sequence (unit 52) and are inferred for the lower grade part of the sequence to the west. Evidence for this $P$ range consists of the sparse occurrence of relict anda, indicating low $P$, and the presence of gt in both metabasic and metapelitic rocks, suggesting intermediate $P$. Metamorphism may have begun earlier in the highest grade, eastern, part of the sequence. Geologic relations in the Healy quadrangle indicate that metamorphism preceded, and continued during, intrusion of an Early Cretaceous pluton $\left(105-\mathrm{Ma}{ }^{40} \mathrm{Ar} / 39 \mathrm{Ar}\right.$ $\mathrm{hb}$ incremental-heating plateau age) into unit 52. The pluton generally crosscuts the metamorphic fabric but, locally, igneous contacts are migmatitic, and in places the pluton is foliated (Csejtey and others, 1986). Weak metamorphic effects also have been noted in plutonic rocks of Late Cretaceous (70 Ma) age farther east within unit 52 (W.J. Nokleberg, oral commun., 1987). Metamorphism of this sequence may have been part of the $\mathrm{M}_{2}$ metamorphic episode that affected unit 47 to the north. A similar eastward increase in metamorphic 
grade occurs in $\mathrm{M}_{2}$ assemblages within the adjacent part of unit 47 south of the Hines Creek fault (DuselBacon, Csejtey, and others, in press).

Problematic tectonic origin of Cretaceous metamomhism and an alternative interpretation of Early Cretaceous isotopic ages

The assumption that much of east-central Alaska was metamorphosed during Cretaceous time is based on the interpretation that isotopic ages from throughout the region record uplift and cooling (to blocking temperatures of about $500^{\circ} \mathrm{C}$ in hb and about $300^{\circ} \mathrm{C}$ in bt) that followed (by not more than 20 to 40 m.y.) an initial episode of crustal thickening and metamorphism. Northward migration and accretion of the Wrangellia terrane against the North American margin, which would have included the rocks of east-central Alaska north of the McKinley and Denali faults, might be a possible cause of Cretaceous crustal thickening, but the timing of the accretion appears to be too late to explain the widespread Early Cretaceous (110 to $135 \mathrm{Ma}$ ) isotopic ages. As discussed in a subsequent section, accretion of the Wrangellia terrane is believed to have postdated the early Late Cretaceous (Cenomanian: 98 to $91 \mathrm{Ma}$ ) age of the youngest flysch in a basin that separated the Wrangellia terrane from North America, and to have resulted in intermediate-P metamorphism and synkinematic plutonism within the flysch basin at about 70 to $56 \mathrm{Ma}$. The mid- to Late Cretaceous metamorphism of units 50 to 52 that crop out just north of the McKinley fault probably overlaped with accretion of the Wrangellia terrane.

Given the problem of identifying the cause of a compressional episode in Early Cretaceous time, an alternative possibility is that the Early Cretaceous ages may not date the time of crustal thickening and heating but instead date uplift and cooling, perhaps brought about by extension, that followed the latest Triassic to Early Jurassic compressional episode (discussed above) that affected units 37 and 39 near the United States--Canadian boundary. The original western extent of this episode is unknown. It is possible that metamorphism of other units in the Yukon-Tanana upland, whose metamorphic age is either given as Early Cretaceous or is bracketed between Paleozoic and Early Cretaceous time, may have been initially heated during the latest Triassic to Early Jurassic episode.

An argument in favor or this interpretation is the fact that oceanic rocks of unit 38 and associated ultramafic rocks ( $\left.M z P_{2} \mathrm{U}\right)$, both of which are interpreted as having been part of the ocean basin that separated North America from a composite terrane that included the Stikinia terrane (Foster and others, 1987), occur far west of units 37 and 39, suggesting a greater original extent of the accreted composite terrane than is now recognized. Moreover, extensional faulting recently has been proposed for several areas in the YukonTanana upland (Pavlis and others, 1988b; Duke and others, 1988; Hansen, 1989). Structural data collected near the fault contact between the flanks of the sillimanite gneiss dome of unit 46 and the structurally overlying mylonitic greenschist-facies rocks of unit 45 indicate that the latest fault movement was extensional (east to southeast movement of the hanging wall; Pavlis and others, 1988b). Other low-angle faults that place lower grade rocks over higher grade rocks (such as the fault which separates units 41 and 42 from units 43 and 44 ), the relation common in extended terranes, are possible candidates for extensional faulting. A correspondance between the age of extension and the Early Cretaceous isotopic ages remains to be proven, but it appears to be a reasonable supposition because augen gneiss and associated rocks of unit 46 are wallrocks to 90-Ma calderas (Bacon and others, 1990) and therefore were virtually at the surface by that time.

Arguing against latest Triassic to Early Jurassic accretion-related metamorphism throughout much of the Yukon-Tanana terrane time is the fact that latest Triassic to Early Jurassic plutons only occur in association with unit 37 (of possible Stikinia terrane affinity) in the eastern part of the Yukon-Tanana upland, and isotopic ages from upper greenschist- and amphibolite-facies metamorphic rocks in the rest of the upland and adjacent parts of the Alaska Range are predominantly late Early Cretaceous.

\section{AREA OF SOUTHERN ALASKA BETWEEN THE MCKINLEY AND DENALI FAULTS AND THE BORDER} RANGES FAULT SYSTEM

\section{Jurassic metamomhism in the Peninsular and Wrangellia terranes}

Several areas of amphibolite- and greenschist-facies metaigneous rocks and associated metasedimentary rocks crop out in the Alaska Peninsula, the Talkeetna Mountains, the Gulkana area northeast of the Talkeetna Mountains, and the eastern Chugach Mountains. Lithologic assemblages in all areas (units 55 to 60) are similar and include varying amounts of most of the following rock types: amphibolite and other amphibolite-facies rocks including mafic, calcareous, and pelitic schist, bt gneiss, marble, and quartzite or metachert; greenschist-facies rocks including greenschist, greenstone, metavolcaniclastic rocks, phyllite, argillite, and slate; and admixtures of the above rock types with massive to schistose intermediate to mafic plutonic rocks that are variably altered, sheared, and foliated. The association of protoliths (mafic to 
intermediate extrusive and intrusive rocks, siliciclastic rocks, calcareous rocks, and chert) suggests an oceanic affinity for most rocks. Unit 55 (Kakhonak Complex; see Detterman and Reed, 1980), and unnamed wallrocks to Jurassic plutons mapped in the Talkeetna Mountains (see Csejtey and others, 1978), and unit 56 (retrograded schist at the southem edge of the Talkeetna Mountains; Csejtey and others, 1978) are included in the Peninsular terrane. Unit 57 (informally designated metamorphic complex of Gulkana River; see Nokleberg and others, 1986b) crops out along the contact between the Peninsular and Wrangellia terranes. Unit 58 (informally designated Haley Creek metamorphic assemblage; see Plafker and others, 1989b), unit 59 (part of the Strelna metamorphics of Plafker and others, 1989b), and unit 60 (informally designated Dadina River metamorphic assemblage; see Winkler and others, 1981; Aleinikoff and others, 1988; Plafker and others, 1989b) are included by the cited workers in the Wrangellia terrane.

I interpret metamorphism in all the areas to have been part of the same metamorphic episode that was early tectonic or syntectonic with the intrusion of Jurassic batholiths. Assumed protolith ages in the Penisular terrane differ from those known or assumed in the Wrangellia terrane (sheet 2), however, and the widespread metamorphic episode probably was imposed on different protolith assemblages. Evidence for a Jurassic metamorphic age differs in the various areas and is summarized in sheet 2; the reader is referred to the appropriate regional report (fig. 2) for a detailed discussion of these units.

Following the model of Plafker and others (1989b), metamorphism and synkinematic plutonism probably took place within a magmatic arc(s) that developed as a result of left-oblique subduction of the Farallon plate beneath a composite terrane composed of the Peninsular, Wrangellia, and Alexander terranes.

Possible correlatives of Jurassic metamorphism of the Peninsular and Wrangellia terranes in southern and southeastern Alaska

Unit 61 consists of a diverse sequence of greenschist- and epidote-amphibolite-facies tectonized metaplutonic, metasedimentary, and metavolcanic oceanic rocks. They have been informally called the "Knik River schist" by Carden and Decker (1977) and are described in detail by Pavlis (1983) and Pavlis and others (1988a). This unit is spacially associated with both Jurassic matic and ultramafic plutons that form part of the Border Ranges ultramafic and mafic complex of Burns (1985) (shown on sheet 1 as unit Jmu) and with Early Cretaceous trondhjemite. Pavlis and others (1988a) suggest that metamorphism of this unit accompanied intrusion of the Early Cretaceous ( 135 to $110 \mathrm{Ma}$ ) tonalitic to trondhjemitic plutons. K-Ar ages on rocks from this unit include a 177-Ma age on ac (Carden and Decker, 1977) and three younger ages on hb of 135, 121, and $107 \mathrm{Ma}$ (Pavlis, 1983). These ages are compatible with either a model in which metamorphism took place during Jurassic time (in which case the younger ages were partly or totally reset during Early Cretaceous intrusion), or in which some or all of the rocks were metamorphosed twice, each time in association with nearby plutonism.

The metamorphic history of unit 62 is difficult to assess because this heterogeneous assemblage of metaplutonic and metasedimentary rocks, referred to informally as the Cottonwood Creek complex of Richter and others (1975) and Richter (1976), occurs as a narrow slice within the Denali fault zone that is widely separated from the rest of the complex (probably the Alexander or Wrangellia terrane) from which it was derived.

Unit 63, informally referred to as the metamorphic complex of Tlikakila River, crops out as a northeasttrending belt within the Late Cretaceous and early Tertiary plutons of the Alaska-Aleutian Range batholith (Carlson and Wallace, 1983; Nelson and others, 1983). Metamorphism is known to postdate the Late Triassic protolith age of the youngest rocks. The spatial association between the metamorphic rocks of this unit and the adjacent Late Cretaceous and Tertiary plutons suggests that metmorphism may have been related to either one or both of the plutonic episodes. However, similarities in metamorphic rock types between this unit and unit 55 (discussed above), suggest that at least some of the rocks of the metamorphic complex of Tlikakila River may have been metamorphosed during the widespread episode of metamorphism and tectonism that slightly preceded or accompanied Middle to Late Jurassic plutonism in the Alaska--Aleutian Range and Talkeetna Mountains area.

Unit 94 crops out on Chichagof and Baranof Islands in southeastern Alaska and is also included in the Wrangellia terrane. This unit consists of amphibolite-facies mafic metavolcanic rocks and marine metasedimentary rocks whose protoliths predate the intrusion of Middle to Late Jurassic (168- to 155-Ma KAr ages on bt and hb) diorite plutons (Loney and others, 1967). R.A. Loney (oral commun., 1985) considers that the metamorphism of this unit is unrelated to the intrusion of the Jurassic plutons, because the direction of increase in metamorphic grade bears no relation to the distance from the plutons. However, Johnson and Karl (1985) report that rocks of this unit grade into the dioritic rocks of Jurassic and Jurassic or Cretaceous age and become more migmatitic close to the plutons, implying a genetic connection between plutonism and metamorphism. Because of the uncertainty in the metamorphic history of this unit, the age of metamorphism is widely bracketed between Paleozoic and Early Cretaceous time, allowing for the possibilities that metamorphism occurred long before plutonism, assuming the oldest possible protolith age for the rocks; or 
that metamorphism was associated with plutonism, as appears to be the case in other parts of the Wrangellia terrane basement, as described above.

\section{Medium-arade metamorphism in the adjacent northem Alexander terrane}

The greenschist-facies marble, phyllite, greenschist, mica schist, and weakly metamorphosed late Paleozoic plutons (shown with a diagonal dash overprint) of unit 64 crop out in the Wrangell and Saint Elias Mountains area (MacKevett, 1978; Hudson and others, 1977b; Campbell and Dodds, 1978). Marble is, in part, Devonian in age and may be as old as Cambrian (Gardner and others, 1988).

In the Saint Elias Mountains, the late Paleozoic plutons have been altered to greenschist-facies assemblages. Relations between the metamorphic rocks and the late Paleozoic plutons may indicate that metamorphism in that area was synkinematic with plutonism. These relations, reported by Hudson and others (1977a, b) consist of: (1) limited data that suggest that slightly higher grade metamorphic mineral assemblages are developed adjacent to the plutons; and (2) the fact that the plutons are dominantly foliate and commonly altered, and that contact relations between plutons and country rocks are locally complex, sometimes being sharp and crosscutting and sometimes gradational.

In the southeastern McCarthy quadrangle, a pluton of Middle Pennsylvanian age (shown as a weakly metamorphosed pluton of unit 65, discussed below) intrudes both the Alexander and Wrangellia terranes, thereby indicating that the two terranes have been sutured since late Paleozoic time (MacKevett and others, 1986; Gardner and others, 1986). Because of this Middle Pennsylvanian minimum age for the juxtaposition of the two terranes, low-grade metamorphism in much of the Alexander terrane (this unit), like the slightly higher grade $M_{1}$ metamorphism in the Strelna Metamorphics of the Wrangellia terrane (unit 59) may have been associated with the intrusion of Late Jurassic plutons. Although Late Jurassic plutons have not been mapped within the Alexander terrane in Alaska, Late Jurassic to Early Cretaceous (160 to $130 \mathrm{Ma}$ ) plutons make up a major intrusive suite within the continuation of these terranes in Canada (Dodds and Campbell, 1988). Geologic evidence from this unit in Canada suggests that regional metamorphism and deformation may have occurred during latest Jurassic to earliest Cretaceous time (about 160 to $130 \mathrm{Ma}$ ) and been associated with plutonism of that age (R.B. Campbell and C.J. Dodds, written commun., 1986). Evidence on which Campbell and Dodds base this interpretation consists of: (1) metamorphism and deformation appear to postdate the deposition of Upper Triassic strata that probably rest unconformably on Paleozoic rocks but nevertheless appear to be equally deformed and metamorphosed; (2) the younger plutons within the belt of 160- to 130-Ma plutons seem clearly to post-date the metamorphism and deformation in the northeast where they produce distinct contact metamorphic aureoles; and (3) the older plutons of this group to the southwest may have been intruded during the metamorphism and deformation, because they are commonly elongate parallel to the regional structural grain, but they clearly have local cross cutting contacts and probably in part post-date those events.

The late Paleozoic to Early Cretaceous age constraints given for this unit reflect the possibility that one or both metamorphic episodes discussed above may have affected different parts of this unit.

\section{Post-Early Jurassic to pre-mid-Cretaceous(?) low-arade metamorphism of the Wrangellia terrane}

Weakly metamorphosed oceanic rocks of the Wrangellia terrane crop out south of the Talkeetna thrust and Denali fault, and north of faults that separate them from the belt of greenschist- and amphibolite-facies rocks that constitute the basement of the Peninsular and Wrangellia terranes. These weakly metamorphosed rocks, shown as unit 65, include upper Paleozoic arc-related metavolcanic and metaplutonic rocks, metalimestone, argillite, and metachert; overlying Middle Triassic argillite, Upper Triassic metabasalt (Nikolai Greenstone), and Upper Triassic and Lower Jurassic metasedimentary rocks of the McCarthy Formation; and, north of latitude $62^{\circ}$, small areas of overlying Triassic metalimestone, and Mesozoic marine metasedimentary rocks.

Most rocks have not been penetratively deformed (except near major faults) and exhibit well-preserved volcanic, sedimentary, or plutonic textures (MacKevett, 1978; Richter, 1976; W.J. Nokleberg, oral commun., 1984; Beard and Barker, 1989). Locally, however, in the general area that is proposed to be the leading edge along which the Wrangellia terrane was accreted (Csejtey and others, 1982), rocks are weakly phyllitic or schistose in the central Alaska Range (Smith, 1981; Nokleberg and others, 1985) and intensely folded and sheared in the Talkeetna Mountains (Csejtey and others, 1978).

Triassic greenstone in most areas contains the assemblage ch-pr-pu-ab-ep, indicating prehnitepumpellyite-facies conditions (Richter, 1976; MacKevett, 1978; Csejtey and others, 1978; Smith, 1981; Nokleberg and others, 1985). CAl values of 5.5 to 6.0 from Upper Triassic conodonts collected in the McCarthy quadrangle from the Nizina and Chitistone Limestones and the lower part of the McCarthy Formation suggest metamorphic temperatures of about 350 to $450^{\circ} \mathrm{C}$ (M.W. Mullen, oral commun., 1989). Locally, in the more deformed northern areas of this unit, greenstone may contain the assemblage ac-ch-ep$a b$, indicating lower greenschist-facies conditions. 
The metamorphic grade of these late Paleozoic metavolcanic and metaplutonic rocks is generally comparable to that of the low-grade Mesozoic rocks. In the northeastern Gulkana quadrangle, the Ahtell pluton contains metamorphic wm, ch, ab, and qz (W.J. Nokleberg, written commun., 1988). Metamorphic minerals developed in the correlative dionite complex of Richter (1976) consist of ac, ch, ep, and wm (Barker and Stern, 1986). Late Paleozoic metavolcanic rocks in the northwestern Nabesna quadrangle generally contain the low-grade assemblage ch-ep-pu, except near the diorite complex where it has been recrystallized to massive, fine-grained assemblages of hb, ep, ch, and feldspar (Richter, 1976). In the southeastern $\mathrm{McC}$ arthy quadrangle, the (informal) Bamard Glacier pluton of Middle Pennsylvanian age (309 $\pm 5-\mathrm{Ma} \mathrm{U}-\mathrm{Pb}$ age on zircon; Gardner and others, 1988) is generally unfoliated, but, locally, it is cataclastically deformed (MacKevett, 1978). It is this pluton, mentioned in the previous section, that is intrusive into both the lowgrade rocks of unit 65 to the west, included in the Wrangellia terrane, and the greenschist-facies rocks of unit 64 to the east, included in the Alexander terrane, thereby indicating that the two terranes were sutured together by Middle Pennsylvanian time (MacKevett and others, 1986; Gardner and others, 1988). Although the data are inconclusive, the pluton is tentatively shown on sheet 1 to have been weakly metamorphosed along with the Wrangellia terrane wallrocks on the west, although numerous other possible correlations of its metamorphic history are possible given the uncertainty of the timing of metamorphism in this region.

The age and cause of metamomhism may be different in different parts of unit 65 . Because the metamorphic grade is so low, it is difficult to determine with certainty whether some associated rocks have been metamorphosed. In the southern part of this unit, the CAl values from the Late Triassic conodonts indicate that metamorphism is post-Late Triassic in age. The minimum metamorphic age in that area is uncertain, but I also assume that it postdates the Lower Jurassic part of the McCarthy Formation. A tentative Middle or Late Jurassic minimum age of metamorphism for at least some areas of this unit is suggested by the apparent lack of metamorphism in the Upper Jurassic and Lower Cretaceous Nutzotin Mountains sequence in the Nabesna quadrangle (Richter, 1976) and in the Jurassic and Cretaceous sedimentary rocks that overlie the McCarthy Formation in the Valdez and McCarthy quadrangles (Winkler and others, 1981; MacKevett, 1978).

Hornblende and biotite from the diorite complex in the northeastern part of unit 65 yield Early Jurassic KAr ages (Richter and others, 1975), but it is uncertain whether these ages (1) date the predominant period of metamorphism in that area, (2) provide a minimum age for a late Paleozoic or early Mesozoic episode, or (3) represent a partial resetting of the Pennsylvanian protolith age by a possible Cretaceous metamorphic episode, described below.

Metamorphism in some areas along the southern margin of unit 65 may have been associated with the intrusion of the Jurassic plutons that I propose occurred during the greenschist- to amphibolite-facies metamorphism of the Strelna Metamorphics (unit 59) to the south. Although the two units that may grade into each other are separated by a thrust fault of Cretaceous age (Chitina fault: Gardner and others, 1986), an overall proximity of the units during the Late Jurassic intrusive and metamorphic episode is suggested by the facts that (1) a Late Jurassic pluton also intrudes unit 65 in one area in the westem McCarthy quadrangle, (2) higher grade unit 59 includes a minor component of Upper Triassic rocks that are correlated with those of unit 65 , and (3) metamorphic temperatures, as determined from Late Triassic conodonts, are comparable across the Chitina fault (that is, about 350 to $450^{\circ} \mathrm{C}$ to the north and about $350^{\circ} \mathrm{C}$ to the south: M.W. Mullen, written commun., 1989).

Some data suggest an altemative or, perhaps, additional, mid-Cretaceous metamorphic age for at least the northern part of unit 65. Field and petrographic observations in the Talkeetna Mountains and the eastern Alaska Range suggest that Jurassic and Cretaceous rocks that overlie the Triassic Nikolai Greenstone also have undergone low-grade metamorphism (Béla Csejtey, Jr., written commun., 1984; Nokleberg and others, 1985). Three K-Ar whole-rock ages from samples of the Nikolai Greenstone from the southern part of this unit in the central McCarthy quadrangle fall on a 112 \pm 11 -Ma isochron (Silberman and others, 1981).

Silberman and his coworkers (1981) propose that the late Early Cretaceous K-Ar ages from the McCarthy quadrangle date an episode of low-grade metamorphism that was caused by frictional heating that accompanied the accretion of the Wrangellia terrane to the North American margin. Arguing against this hypothesis for at least the McCarthy quadrangle, however, is the fact that the Upper Triassic rocks show no sign of being deformed (although they have been heated to about 350 to $450^{\circ} \mathrm{C}$ since the Late Triassic). Assuming that the late Early Cretaceous K-Ar ages do in fact date the timing of low-grade metamorphism in the central McCarthy quadrangle, an altemative interpretation is that metamorphism may have been coeval with the northeast-directed, Early Cretaceous movement along the nearby Chitina fault (Gardner and others, 1986 ) that placed the medium-grade metamorphic rocks (unit 59) and synkinematic Jurassic plutonic rocks of the Wrangellia terrane on top of the low-grade rocks of unit 65.

The localized development of a penetrative fabric and higher $T$ ac-bearing mineral assemblages in the central Alaska Range and the Talkeetna Mountains suggests that metamorphism, at least in these areas, occurred during late Mesozoic accretion. Both areas were near the leading edge along which this terrane is 
thought to have been accreted in mid-Cretaceous time (Csejtey and others, 1982; Nokleberg and others, 1985).

Similar low-grade oceanic rocks crop out in southeastern Alaska where they are shown as units 91 and 99. Unit 91 is included in the northern part of the Taku terrane by Monger and Berg (1987), but subsequently has been reinterpreted as part of the Wrangellia terrane by Plafker and others (1989a); unit 99 is included in the Wrangellia terrane by Monger and Berg (1987). The age and tectonic origin of their metamorphism are also uncertain.

\section{Mid-Cretaceous to early Tertiary metamorphism}

\section{Low-grade metamorphism within a compressed flysch basin}

Very weakly metamorphosed and highly deformed flyschoid rocks, primarily metagraywacke, semischist, and argillite, and rocks from several tectonically interleaved fragments within the flysch, crop out as a northeastward-tapering wedge (shown as unit 67) in the central Alaska Range between the low-grade rocks of the Wrangellia terrane to the southeast, and the unmetamorphosed to moderately metamorphosed rocks of the continental margin to the northwest. Flyschoid rocks are Late Jurassic to mid-Cretaceous

(Cenomanian) in protolith age (Csejtey and others, 1986). Tectonic fragments include protoliths that range in age from Late Devonian to Late Jurassic age and include a variety of sedimentary, volcanic, and ophiolitic rocks (Jones and others, 1980). The tectonic juxtaposition of the disparate fragments (terranes) included within this unit is considered to have taken place during mid-Cretaceous time (Csejtey and others, 1978, 1982; Jones and others, 1980). According to Csejtey and others (1982), the flyschoid rocks were deposited in a basin between the North American craton and the approaching Talkeetna superterrane (equivalent to the composite Peninsular-Wrangellia terrane) to the south, and the small terranes within the flysch were transported in front of the superterrane by northward plate movement. Because the Wrangellia and Alexander terranes are stitched together by a Pennsylvanian pluton, as mentioned in a previous section, the superterrane also must have included the Alexander terrane as its southeasternmost component.

The dominant structural style of this metamorphic unit is compression and attendant thrust faulting that has juxtaposed fragments of what were parts of extensive coherent terranes (Csejtey and others, 1978; Jones and others, 1980). Deformation and recrystallization within the flysch terrane is most intense along zones of concentrated shear; rocks in these zones are commonly phyllitic, semischistose, or protomylonitic. The degree of metamorphism may vary within unit 67 , but this aspect of the terranes has not been studied in detail. Metamorphic minerals developed in flyschoid rocks indicate metamorphic conditions characteristic of the prehnite-pumpellyite facies (Dusel-Bacon, Csejtey, and others, in press).

Metamorphism is bracketed between the mid-Cretaceous age of the youngest metamorphosed rocks and the latest Paleocene and Eocene age of the overlying unmetamorphosed sedimentary and volcanic rocks, and the early Tertiary age of postmetamorphic granitoids that intrude the flyschoid rocks (Csejtey and others, 1982, 1986). The apparent increase in metamorphic grade toward zones of shearing, together with age brackets for accretion that are approximately the same as those for low-grade metamorphism, suggest that much of the metamorphism probably accompanied northward migration and accretion. Low-grade metamorphism of some of the elements of the tectonic fragments may have occurred even earlier.

Intermediate-P metamorphism of the Maclaren metamorphic belt

The Maclaren metamorphic belt consists of a largely fault-bounded, 140-km-long, roughly symmetrical, intermediate-P (Barrovian) sequence of: (1) prehnite-pumpellyite-facies metasedimentary rocks and metagabbro (unit 68); (2) greenschist-facies phyllite, metagraywacke, marble, quartzite, metapelite, and greenstone (unit 69); and (3) amphibolite-facies schist, gneiss, and amphibolite (unit 70) intruded by foliated, synkinematic plutons of intermediate composition, shown as unit TKg with a cross pattern (Smith, 1981; Csejtey and others 1982, 1986; Nokleberg and others, 1985). Protoliths are Triassic to Cretaceous in age.

Intermediate-P conditions for the sequence are indicated by the presence of ky (+sil+gt+st) in pelitic schist and gneiss of unit 70 (Smith, 1981), and sil pseudomorphs after ky (L.S. Hollister, written commun., 1985). Kyanite is also reported to occur in amphibolite (Smith, 1981)--further evidence of intermediate-, or even, high-P conditions. Andalusite has been reported from two localities, one near the western and one near the eastern boundary of unit 70 (Dusel-Bacon, Csejtey, and others, in press). These reported occurrences of anda warrant further investigation, but they may simply indicate that higher structural levels are exposed on the ends of the metamorphic belt, relative to deeper level exposure in the central part of it.

Where not affected by tectonic shortening, metamorphic grade increases gradually from the flanks of the sequence toward its core. Along the southern limb of the belt, lower grade rocks dip northward under higher grade rocks to form an inverted metamorphic sequence (Smith, 1981). East of longitude $147^{\circ}$, there is an abrupt, rather than gradational, contact between greenschist- and amphibolite-facies rocks due to tectonic shortening along steep north-dipping faults (Nokleberg and others, 1985). A similarly sharp change 
in metamorphic grade occurs on either side of a north-dipping thrust (overturned to the south along its eastem end) that forms the southern margin of the foliated plutonic body, referred to as the East Susitna batholith (Nokleberg and others, 1985; Smith, 1981). Deeper level rocks are exposed north of the thrust, as indicated by the first appearance of sil and, with one exception, ky in upper plate rocks adjacent to the thrust (Smith, 1981).

Metamorphic recrystallization occurred during and after two dynamic phases of a prolonged metamorphic episode (Smith, 1981). The concordancy between intrusive contacts and metamorphic foliations in the granitoids and in the metamorphosed wall rocks, together with an increase in metamorphic grade toward the East Susitna batholith, indicates that the foliated granitoids intruded during the early part of the metamorphic episode (Smith, 1981; Nokleberg and others, 1985). This may have been toward the end of an early shearing phase or interkinematically before a final phase of shearing (Smith, 1981). U-Pb data on zircon from schistose quartz diorite indicate a 70 $\pm 7-\mathrm{Ma}$ intrusive age of the East Susitna batholith (Aleinikoff and others, 1982). U-Pb data on sphene and K-Ar data on biotite from the same rock indicate a 56-Ma metamorphic age (Aleinikoff and others, 1982), which apparently marks the end of the prolonged Late Cretaceous to early Tertiary metamorphic episode. Biotite from pelitic schist gives a similar K-Ar age of $57 \mathrm{Ma}$ (Smith and Lanphere, 1971). Rapid uplift and cooling during metamorphism is indicated by the fact that approximately the same age is given by sphene, whose closure temperature is greater than $600{ }^{\circ} \mathrm{C}$ (Mattinson, 1978), and biotite, whose closure temperature is about $280^{\circ} \mathrm{C}$ (Harrison and others, 1985).

Metamorphism and tectonic shortening of the Maclaren metamorphic belt apparently resulted from the accretion of the previously amalgamated Peninsular and Wrangellia terranes to the Yukon-Tanana and Nixon Fork terranes of the ancient North American continent (Csejtey and others, 1982) and the synorogenic intrusion of the East Susitna batholith (Nokleberg and others, 1985). The flyschoid protoliths of the Maclaren metamorphic belt, as well as those of unit 67 , were deposited mostly in the narrowing and subsequently collapsed ocean basin between the converging terranes (Csejtey and others, 1982; Nokleberg and others, 1985).

The location in which the convergence, deformation, plutonism, and metamorphism took place is disputed, however. Multiple lines of field and isotopic evidence suggest that the Maclaren metamorphic belt and East Susitna batholith are the offset equivalents of the Kluane Schist and Ruby Range batholith in Yukon Territory, displaced $400 \mathrm{~km}$ by right-lateral Cenozoic movement along the Denali and McKinley faults (summary of evidence given in Nokleberg and others, 1985; see also Aleinikoff and others, 1987). Nokleberg and his coworkers (1985) postulate that intense deformation and prograde metamorphism of the belt began during mid- to Late Cretaceous time as a result of the accretion of the Wrangellia terrane onto the North American margin further to the south and continued during early Tertiary time as a result of the northward migration of the flyschoid (Maclaren) terrane and the Wrangellia terrane along the North American margin. Csejtey and others (1982) dispute the correlation between the two metamorphic-plutonic complexes and propose instead that regional metamorphism of the Maclaren metamorphic belt occurred in place, extends across the McKinley fault, and is only slightly offset by it. Although there is an apparent similarity in metamorphic grade and a similar eastward increase in metamorphic grade on either side of the McKinley fault in the east-central part of the Healy quadrangle, metamorphic data are insufficient to document continuity of metamorphic history across the fault. Arguing against continuity of metamorphic history on either side of the McKinley fault is the occurrence of a fault-bounded block of unit 54 (Windy terrane) between the areas of amphibolite-facies rocks that Csejtey would correlate across the fault (units 52 and 70 ).

\section{AREA OF SOUTHERN AND SOUTHEASTERN ALASKA THAT LIES SOUTH OF THE BORDER RANGES FAULT SYSTEM}

\section{Jurassic blueschist- to greenschist-facies metamorphism}

A belt of transitional, and tectonically intermixed high-P blueschist-facies to intermediate-P greenschistfacies metabasalt, metachert, mica schist, marble, and fine-grained clastic rocks, derived from oceanic protoliths, crops out immediately south of the Border Ranges fault system, at the northern margin of the Chugach terrane. The belt, shown as unit 71 , extends discontinuously for about $750 \mathrm{~km}$ from Kodiak Island on the west to the Copper River on the east. This unit consists of fault-bounded, commonly internally imbricated blocks, and includes, from southwest to northeast, the Raspberry Schist of Roeske (1986) on Kodiak and Afognak Islands, the informally designated schist of Seldovia on the Kenai Peninsula (Forbes and Lanphere, 1973; Carden and others, 1977), the informally designated schist of Iceberg Lake near Tazlina Glacier (Winkler and others, 1981; Sisson and Onstott, 1986), and the informally designated schist of Liberty Creek just west of the Copper River (Metz, 1976; Winkler and others, 1981; Plafker and others, 1989b). Protolith ages are unknown. 
In most areas, greenschists that contain ch+ac commonly are finely intercalated with blue-amph-bearing schists that contain cr+ep (Forbes and Lanphere, 1973; Carden and others, 1977; Carden, 1978; Winkler and others, 1981). Glaucophane (+ep) has been identified only in the Raspberry Schist on Afognak Island, and the assemblage gt+cr+ep is present in the schist of Iceberg Lake near Tazlina Glacier (Winkler and others, 1981). Lawsonite coexists with blue amph at scattered localities along the belt (sheet 1).

The coexistence of blue amphibole with ep, and in one area with gt, is indicative of the high-T subdivision of the blueschist facies (Taylor and Coleman, 1968; Evans and Brown, 1987). However, the sporatic occurrence of Iw, which is diagnostic of the low-T subdivision of the blueschist-facies, indicates that temperatures during metamorphism were probably near the boundary between the two subdivisions. Phase equilibria that involve the breakdown of pu to form ep (Nitsch, 1971), and the breakdown of lw to form zo (Franz and Althaus, 1977), suggest temperatures between about 350 and $400^{\circ} \mathrm{C}$. Phase equilibria and $\mathrm{cr}$ composition indicate crystallization at about $6 \pm 2 \mathrm{~kb}$ for the schists of Iceberg Lake and Liberty Creek (Sisson and Onstott, 1986). This P-T range is consistent with the hypothesis of Carden and others (1977) that the finely developed intercalation of ac-ch-bearing layers and cr-bearing layers in the Raspberry Schist (equivalent to the Kodiak schist unit of Carden and others, 1977) and the schist of Seldovia are probably due to minor variations in original chemistry of layers that were metamorphosed under conditions close to the boundary between the greenschist and blueschist facies (Turner, 1981).

Detailed mapping in the area of Kodiak Island indicates that post-metamorphic faults separate blocks ranging from meters to hundreds of meters wide, and that overall the metamorphic grade of the blocks increases from southeast to northwest (Roeske, 1986). To the north, the schist of Seldovia also occurs as fault-bounded blocks of varying metamorphic grade (S.M. Roeske, oral commun., 1984).

The schist of Iceberg Lake makes up an elongate, 40 - by $4-\mathrm{km}$, fault-bounded belt enclosed by the lowgrade McHugh Complex (unit 72) near the Tazlina Glacier. Several small elongate blocks of this unit (too small to show on sheet 1) also occur in mélange along the Border Ranges fault system to the north (Winkler and others, 1981). Similar metamorphic mineral assemblages (primarily those of the greenschist-facies) are developed in the schist of Liberty Creek and the schist of Iceberg Lake, but rocks are noticeably finer grained (generally less than $3 \mathrm{~mm}$ ) in the former than in the latter (Plafker and others, 1989b). Crossite-bearing rocks in the schist of Iceberg Lake locally contain gt and those in the schist of Liberty Creek, hematite.

Data for several isotopic systems suggest a Jurassic (primarily Early to early Middle Jurassic) age for the intermediate- to high-P greenschist-facies episode. K-Ar ages on wm and $\mathrm{cr}$ (as well as on ac from the schist of Seldovia) from unsheared rocks in all units except the schist of Liberty Creek range from Early to Late Jurassic, from 190 to about $152 \mathrm{Ma}$ (Forbes and Lanphere, 1973; Carden and others, 1977; Winkler and others, 1981). Crossite-bearing rocks from the Raspberry Schist give an Early Jurassic age of $196 \mathrm{Ma}$ for a $\mathrm{Rb}-\mathrm{Sr}$ whole rock-ph isochron and a $204 \pm 8 \mathrm{Ma}$ for a U-Pb isochron of sph, wm, ab, and amph (Roeske and Mattinson, 1986). Near the eastern end of the belt, cr and ph from unsheared rocks of the schist of Iceberg Lake yield ${ }^{40} \mathrm{Ar} /{ }^{39} \mathrm{Ar}$ plateau ages of about $185 \mathrm{Ma}$ (Sisson and Onstott, 1986).

Strongly sheared rocks from the schist of Iceberg Lake yield Early Cretaceous (138 to $113 \mathrm{Ma}$ ) K-Ar mineral ages (Winkler and others, 1981), indicating partial resetting subsequent to the well-dated Jurassic metamorphic episode. Resetting of the isotopic ages may have taken place during the emplacement of the schistose rocks of the McHugh Complex, the adjacent seaward subduction complex (unit 72) that was primarily accreted between Early Cretaceous and early Tertiary time (Winkler and others, 1981).

Early Cretaceous (123-107 Ma) K-Ar whole-rock ages have been determined for three samples of sheared rock from the schist of Liberty Creek (Plafker and others, 1989b), but interpretation of these ages is uncertain. Because of the very fine grain size of the unit, no minerals suitable for isotopic dating have been successfully separated. If the schist of Liberty Creek, like the rest of the belt, was originally metamorphosed during a Jurassic subduction-related transitional greenschist- to blueschist-facies episode, then its Early Cretaceous ages probably represent the same resetting event, attributed to emplacement of the McHugh Complex, that was proposed for the nearby schist of Iceberg Lake. Alternatively, the Early Cretaceous wholerock ages may in fact date the timing of subduction-related metamorphism of the schist of Liberty Creek. In this case, a better analog for its metamorphic history would be that of the sparse blue-amph-bearing schist within the prehnite-pumpellyite- to greenschist-facies mélange of unit 73 (Kelp Bay Group) of the Chugach terrane on Chichagof Island, over $600 \mathrm{~km}$ to the southeast (discussed below). Arguing against the analogy with the rocks on Chichagof Island is the fact that blue amphibole has only been found at one locality on Chichagof Island, whereas it occurs across a much larger area and in more abundance in the schist of Liberty Creek.

Similarities in lithology, mineralogy, and isotopic ages suggest that all parts of this unit, with the possible exception of the schist of Liberty Creek, are segments of a formerly continuous belt of accreted, subductionrelated rocks. Metamorphism of the Raspberry Schist and schist of Seldovia is thought to have occurred as a result of northwest-directed subduction which was coeval with magmatism in the nearby Alaska-Aleutian Range during Early Jurassic time (Carden and others, 1977; Connelly, 1978). Plafker and others (1989b) concur with this general hypothesis and propose that northward to eastward subduction beneath the 
(composite) Peninsular-Wrangellia terrane began in Late Triassic time and continued to Middle(?) Jurassic time as a result of left-oblique subduction of the Farallon plate. As pointed out by Plafker and his coworkers, the juxtaposition across the Border Ranges fault system of the low-T, high-P rocks of unit 71 with the approximately coeval high-T plutonic and volcanic rocks of the Triassic to Jurassic arc (including unit Jmu and the Talkeetna Formation that forms part of unit N) implies structural disruption of the seaward margin of the arc. On the basis of the separation between the inner margins of accretionary prisms and magmatic belts in modern arcs, Plafker and others (1989b) proposed that the observed juxtaposition indicates relative underthrusting, on the order of $50 \mathrm{~km}$, of the high- to intermediate-P rocks beneath the plutonic rocks.

\section{Jurassic te early Tertiary low-arade metamorphism of Chugach and Yakutat terranes mélange}

Tectonic mélange, included in the mélange facies of the Chugach terrane (Plafker and others, 1977), occurs immediately outboard of the Border Ranges fault or, in a few areas in southern Alaska, separated from it by the high- to intermediate-P subduction complex discussed above. The mélange makes up all of unit 72 and the inboard parts of units 73 to 75 . It consists of disrupted, deformed, and weakly metamorphosed blocks, ranging from tens of meters to several kilometers in longest dimension, of greenstone, mafic schist, metatuff, metagraywacke, metaargillite, metachert, metalimestone, phyllite, quartzite, serpentinite, and mafic plutonic rocks. Blocks are aligned in a sheared matrix of argillite, metatuff, and metachert.

Unit 72 crops out around the Gulf of Alaska and records primarily prehnite-pumpellyite-facies conditions; exotic metamorphic blocks in the mélange locally record blueschist-facies conditions. This unit makes up the McHugh Complex in the Chugach Mountains (Clark, 1973; Tysdal and Case, 1979; Winkler and others, 1981), the Seldovia Bay complex in the Kenai Mountains (Cowan and Boss, 1978), and the Uyak Complex in the Kodiak Island area (Connelly, 1978). Near Seldovia, a small area of this unit is included in the Kachemak terrane by Jones and others (1987). Paleontologic ages of radiolarians from the mélange matrix of this unit range from Late Triassic to mid-Cretaceous (Albian to Cenomanian), the bulk of the fossil ages being Late Jurassic to Early Cretaceous (Plafker and others, 1977; Connelly, 1978; Nelson and others, 1987). Fossils from blocks within the mélange are as old as late Paleozoic.

Unit 73 crops out in southeastem Alaska and is made up primarily of mélange (revised Kelp Bay Group of Johnson and Karl (1985)) that records prehnite-pumpellyite-facies, lower greenschist-facies, and rare blueschist-facies conditions (Decker, 1980). Along its western margin, unit 73 also includes a less extensive sequence of moderately deformed and disrupted bedded turbiditic metasedimentary and metavolcanic rocks (Sitka Graywacke) metamorphosed under prehnite-pumpellyite- and greenschist-facies conditions; these rocks are included in the flysch facies of the Chugach terrane (Plafker and others, 1977). Blocks within the mélange are Triassic or Jurassic, Late Jurassic (Tithonian), and Early Cretaceous (Valanginian) in age (Loney and others, 1975; Decker and others, 1980; Johnson and Karl, 1985; Brew and others, 1988). Deposition of the mélange matrix took place, in part, during the Late Jurassic (Tithonian; Brew and others, 1988) and presumably continued during at least the Early Cretaceous (age of the youngest blocks; Decker, 1980, Johnson and Karl, 1985; Brew and others, 1988). The depositional age of the bedded rocks is unknown but is considered to be Cretaceous on the basis of correlation with lithologically similar rocks in the Valdez Group and Yakutat Group to the northwest (Plafker and others, 1977; Brew and Morrell, 1979).

Around the Gulf of Alaska, rocks of the flysch facies of the Chugach terrane (units 77 and 78 , discussed below) have been shown to have a younger depositional, and, presumably, metamorphic age than that of the inboard mélange facies of the Chugach terrane (unit 72). In southeastern Alaska, however, the depositional age of the flysch facies is unknown and separate metamorphic histories have not, as yet, been demonstrated for the two tectonic facies. For this reason, both of these tectonic facies are included in unit 73 and in two related polymetamorphic units (units 74 and 75 ) in which the early low-grade metamorphic episode was overprinted by regionally extensive, low- $P$, thermal metamorphism associated with Eocene plutonism (Loney and others, 1975; Loney and Brew, 1987).

The mélange of both areas is considered to be a subduction complex consisting of oceanic sedimentary and igneous rocks, offscraped fragments of continental margin, or older subduction assemblages (Clark, 1973; Moore and Connelly, 1979; Plafker and others, 1977; Cowan and Boss, 1978; Decker, 1980; Winkler and others, 1981). The relationship of crystallization to deformation observed on Kodiak and Afognak Islands suggests that metamorphism occurred during active underthrusting, continued after accretion of the subduction complex onto the overthnust plate, and was followed by late fracturing and cataclasis during uplift of the complex (Connelly, 1978). This evolution is a reasonable hypothesis for the other areas of mélange as well. As pointed out by Connelly (1978), a similar progression of deformation has been proposed for the Franciscan Complex (subduction complex; Glassley and Cowan, 1975).

Accretion of the mélange facies may have taken place over a long time span that extended throughout the Jurassic and Cretaceous. This prolonged period of accretion is suggested by Plafker and others (1989b) because of an apparent southward decrease in age from Late Triassic to mid-Cretaceous noted in the westem Valdez quadrangle (Winkler and others, 1981), and the probable convergent plate motion that is indicated along the southern margin of the (composite) Peninsula-Wrangellia-Alexander terrane during much 
or all of Jurassic and Cretaceous time (Engebretsen and others, 1985). As suggested by Plafker and others (1989b), the earliest accretion of Chugach terrane rocks is probably represented by the Jurassic intermediate- to high-P greenschist-facies metamorphism of unit 71.

Although the innermost parts of the mélange complex of the Chugach terrane may have been accreted as early as Jurassic time, accretion and metamorphism of much of units 72 to 75 probably occurred in Early to mid-Cretaceous time, following accumulation of the youngest matrix material. Low-grade metamorphic minerals that were interpreted by Decker and his coworkers (1980) to have formed during subduction and accretion of unit 73 on Chichagof Island give Cretaceous K-Ar ages (106-91 Ma; Decker and others, 1980). Early Cretaceous ( 135 to $110 \mathrm{Ma}$ ) plutons that intrude unit 72 northeast of Anchorage are interpreted to be the result of near-trench plutonism that occurred during underthrusting of the mélange complex (Pavlis, 1982; Pavlis and others, 1988a). An early Tertiary minimum metamorphic age is indicated by the facts that: (1) emplacement and metamorphism of the mélange complex preceded the probable latest Cretaceous or early Tertiary emplacement and metamorphism of the tectonically underthrust flysch facies of the Chugach terrane that occurs outboard of unit 72; and (2) metamorphic assemblages within flysch and mélange on Baranof Island in southeastern Alaska (units 74 and 75) are overprinted by thermal metamorphism associated with Eocene plutons (Loney and others, 1975).

Lithologically similar mélange composed of structurally disrupted lenses of Upper Jurassic to Lower Cretaceous chert, argillite, conglomerate, mafic volcanic rocks, and rare blocks of exotic lithologies (Hudson and others, 1977b) also occurs within units 79 to 81 of the Yakutat terrane. The Yakutat terrane lies outboard of the Chugach terrane and has been correlated with it by Plafker and others $(1977,1989 \mathrm{~b})$. Mélange of the Yakutat terrane occurs tectonically interleaved with flysch that comprises the dominant part of units 79 to 81 (discussed below); tectonic mixing is on a scale too small to allow delineation of the mélange. As with the Chugach terrane mélange, metamorphism of parts of the Yakutat terrane mélange may have occurred in the Jurassic or Early Cretaceous. At one locality within unit 79, deformed mélange is crosscut by a tonalite pluton (unit $\mathrm{Kg}$ ) that gives discordant K-Ar ages of $96 \mathrm{Ma}$ on $\mathrm{hb}$ and $84 \mathrm{Ma}$ on bt (George Plafker, unpub. data, 1978). It is also likely that, as is the case with the Chugach terrane mélange, blueschist-facies metamorphism affected some of these rocks because glacial erratics of crossite-bearing metabasalt occur locally along Russell Fiord and Yakutat Bay (George Plafker, unpub. data, 1987). The lithology and occurrence of these erratics are most compatible with a source in the ice-covered parts of the Yakutat terrane.

\section{Late Cretaceous to early Tertiary low-P metamorphism of Chugach and Yakutat terranes flysch}

A low-P facies series of low- to medium- (and locally high-) T metamorphosed flysch of the Chugach terrane (units 76 to 78 ) and Yakutat terrane (units 79 to 81) forms an arcuate belt of rocks that extends from the Sanak and Shumagin Islands off the southeast coast of the Alaska Peninsula in the west to the Saint Elias Mountains area south of Yakutat Bay in the east. Protoliths of the Chugach terrane (western and central parts of the belt) consist of a steeply dipping Upper Cretaceous (Maastrichtian) turbidite sequence of graywacke, slate, and locally intercalated conglomerate and volcanic rocks (Moore, 1973; Jones and Clark, 1973; Nilsen and Moore, 1979). Protoliths of the Yakutat terrane (eastern part of the belt) include these rock types, in addition to small amounts of the structurally interleaved mélange (undifferentiated on sheet 1) discussed above.

The flysch of the Chugach terrane forms a north-dipping accretionary prism that was underthrust beneath either the mélange facies of that terrane or beneath the combined Peninsular and Wrangellia terranes to the north. Metamorphic grade within the accretionary prism increases progressively to the east around the Gulf of Alaska where it culminates in the polymetamorphic rocks of the (informal) Chugach metamorphic complex (unit 78) of Hudson and Plafker (1982) that crops out in the eastern Chugach Mountains and the Saint Elias Mountains. Flysch on Sanak and Shumagin Islands underwent laumontitefacies metamorphism that was ascribed by Moore (1973) to burial. Within the rest of the prism, flysch and related rocks underwent prehnite-pumpellyite-facies (unit 76) to lower greenschist-facies (unit 77 and $M_{1}$ of unit 78) low-P metamorphism that probably accompanied north-directed underthrusting of the Chugach terrane beneath the (composite) Peninsular-Wrangellia terrane, and the development of south-vergent folds, during latest Cretaceous to early Tertiary time (Moore and others, 1983; Sample and Moore, 1987; Nokleberg and others, 1989). Metamorphism during this low-grade episode postdates the Maastrichtian age of the protoliths and predates the intrusion of crosscutting tonalitic plutons that give K-Ar ages of $63 \mathrm{Ma}$ on Kodiak Island (Byme, 1982) and approximately 60-50 Ma (data summarized by Plafker and others, 1989b, and Sisson and others, 1989) in the Chugach Mountains.

The Chugach metamorphic complex (unit 78), forms an elongate 200-km-long, and less than 50-kmwide, east-west-trending belt made up of anda- and co-bearing schist and gneiss, and a core zone of silbearing migmatite. These rocks represent the deepest parts of the accretionary prism that makes up the Chugach terrane. They were initially metamorphosed during the greenschist-facies episode that affected the adjacent rocks of unit 77 and further heated under low-pressure amphibolite-facies conditions that developed during the widespread Eocene intrusion of tonalitic plutons. Metamorphic grade generally 
increases from the edges toward the elongate core of the metamorphic complex. This overall increase is independent of the exposed distribution of major plutons, and, as Sisson and others (1989) point out, this progression is not solely a product of contact-metamorphic effects. In addition to the overall distribution of metamorphic grades, local contact metamorphism has produced high-grade rocks near the contacts of large felsic intrusions (Sisson and Hollister, 1988). Amphibolite-facies metamorphism and partial melting in the core of the metamorphic complex overlapped in time with the development of second-generation northvergent folds, steeply dipping cleavage and schistosity, and near horizontal east-west-trending fold axes and lineations (Sisson and Hollister, 1988).

Intrusion and $\mathrm{M}_{2}$ metamorphism of unit 78 postdated the accretion of the upper Paleocene to middle Eocene Orca Group of the Prince William terrane against the southern margin of the Chugach terrane (south of the Contact fault). This relation is indicated by the fact that an elongate 51-Ma tonalite pluton (Winkler and Plafker, 1981) and the metamorphic effects associated with it $\left(M_{2}\right.$ of unit 85; Miller and others, 1984; Sisson and others, 1989) crosscut the Chugach/Prince William terrane boundary near Miles Glacier.

Metamorphic $P$ throughout the metamorphic complex (unit 78) was between 2 and $3 \mathrm{~kb}$ (about $10 \mathrm{~km}$ ) and T between $500^{\circ} \mathrm{C}$ near the edge of the complex to about $650^{\circ} \mathrm{C}$ in its migmatitic core (Sisson and others, 1989). These P-T estimates, together with those from the adjacent greenschist-facies unit 77 , suggest a nearly isobaric P-T-time path in which the rocks of unit 78, already heated to greenschist-facies conditions at a depth of about $10 \mathrm{~km}$ during $M_{1}$, were further heated to amphibolite-facies conditions during $\mathbf{M}_{2}$.

The tectonic origin of the heat that produced both the amphibolite-facies Chugach metamorphic complex and the widespread belt of early Tertiary plutons that crops out within the Chugach terrane and the outboard Prince William terrane is problematic. Marshak and Karig (1977) pointed out that in a normal subduction setting, the temperatures within an accretionary prism, such as the Chugach and Prince William terranes, are much too low to cause partial melting. They proposed that the anomalous near-trench plutonism was the result of eastward migration of a ridge-trench-trench triple junction along the continental margin, and subduction of the Kula-Farallon spreading ridge. An second but related hypothesis proposed by Plafker and others (1989b) suggests that the anomalous heating during the early Tertiary metamorphic and plutonic episode resulted from the opening of a high-T oceanic-slab-free mantle window beneath the continental margin, as the subducting Kula plate pulled away from the Farallon-Pacific plate, in a manner analogous to one described along the San Andreas transform fault system by Dickinson and Snyder (1979). According to a third hypothesis, the high temperatures that produced the Chugach metamorphic complex resulted from a combination of heat introduced by extensive horizotal, as well as vertical, transport of fluids (beginning during initial greenschist-facies metamorphism) followed by felsic melts, both of which were generated from downdip in the subduction zone and involved either subduction of young hot oceanic crust at a high rate and a low angle, or subduction of a spreading ridge (Sisson and Hollister, 1988; Sisson and others, 1989).

A low-P facies series, similar to and probably correlative with that which developed within the Chugach terrane flysch also was formed within Late Cretaceous flysch and the structurally interleaved mélange of the Yakutat terrane (Hudson and others, 1977b). The flysch and mélange of the Yakutat Group are correlative with the flysch and mélange of the Chugach terrane (Plafker and others, 1989b). The Yakutat Group, like the Chugach terrane in south-central and southeastern Alaska, is extensively intruded by Eocene granitoid plutons. Yakutat terrane rocks affected by the low-P metamorphic episode include: (1) laumontite- and prehnite-pumpellyite-facies rocks of unit 79; (2) a narrow fault-bounded sliver of greenschist-facies rocks of unit 80; and (3) epidote-amphibolite- and amphibolite-facies rocks of unit 81 (Hudson and others, 1977b). A steep thermal gradient is indicated by a rapid progressive increase in metamorphic grade from prehnitepumpellyite-facies rocks to an area (oval in plan view) of amphibolite-facies rocks, with only a narrow interval of intervening greenschist-facies rocks (not shown on sheet 1). Within the oval outcrop area of amphibolitefacies rocks, anda porphyroblasts are developed locally, and rocks are characterized by semigranoblastic textures, providing evidence that metamorphism of these rocks was dominantly thermal in nature. The oval outline suggests a buried pluton.

The rest of epidote-amphibolite- and amphibolite-facies unit 81 occurs as an elongate fault-bounded sliver that is separated from the amphibolite-facies rocks of the Chugach terrane (unit 83, described below) by the Fairweather fault to the northeast, and from the prehnite-pumpellyite-facies rocks of the Yakutat terrane by another major fault to the southwest. Tectonic shortening, by thrust faulting or strike-slip faulting with a significant dip-slip component, is suggested by the juxtaposition of high-and low-grade rocks along the southwestern fault contact, and by the absence of intervening greenschist-facies rocks.

Major metamorphism is considered to be latest Cretaceous to early Tertiary in age, based on: (1) the latest Cretaceous protolith age of the youngest rocks; (2) K-Ar ages on hb of about $65 \mathrm{Ma}$, determined for amphibolites (Hudson and others, 1977b), and (3) the interpretation that this unit shared a common metamorphic history with that of the adjacent Chugach terrane discussed above. 
Late Cretaceous to mid-Tertiary intermediate(?)-P metamorphism of Chugach terrane flysch

A sequence of transitional greenschist- to amphibolite-facies rocks (unit 82 ) and amphibolite-facies rocks (unit 83) crops out along the eastem margin of the Gulf of Alaska in the Saint Elias Mountains and Fairweather Range (Brew, 1978; Hudson and others, 1977b; Hudson and Plafker, 1982). Protoliths are interpreted as being turbidites and tholeiite of Late Cretaceous age because of lithologic similarity with the flysch facies of the Chugach terrane (Plafker and others, 1977; Barker and others, 1985). Most boundaries of the sequence are faults. The two fault blocks that make up the higher grade part of the sequence are presumed to have shared the same metamorphic history and to have subsequently been separated by rightlateral displacement along the Fainweather fault (Dusel-Bacon, Csejtey, and others, in press).

The timing and number of metamorphic episodes that affected units 82 and 83 are unknown. A Cretaceous maximum age of metamorphism is proposed on the basis of the probable age of the protoliths. At least some of the metamorphism is known to have occurred prior to the intrusion of crosscutting plutons of intermediate composition that have K-Ar ages on $\mathrm{hb}$ of $61 \pm 2 \mathrm{Ma}$ in the southeastem Yakutat quadrangle (Hudson and others, 1977a) and K-Ar ages of about $52 \mathrm{Ma}$ in the southwestem Skagway quadrangle (George Plafker, unpub. data, 1978). A K-Ar age on hb of $67 \mathrm{Ma}$ from amphibolite in the Nunatak Fiord area, $55 \mathrm{~km}$ northeast of Yakutat, suggests a latest Cretaceous metamorphic age (Barker and others, 1985). In the same area, however, K-Ar ages on hb and bt from metamorphic rocks between Nunatak Fiord and the southwestem Skagway quadrangle range from about 23 to $19 \mathrm{Ma}$, which suggests an additional, or alternative, Miocene metamorphic age; these K-Ar ages fall close to or within the 37- to 21-Ma range of K-Ar ages from widespread felsic intrusive rocks (Hudson and others, 1977b; George Plafker, unpub. data, 1978). Farther to the south, in the area northwest of Cross Sound, metamorphism appears to predate and to be unrelated to the intrusion of Oligocene $\left(28 \pm 8-\mathrm{Ma}{ }^{40} \mathrm{Ar} /{ }^{39} \mathrm{Ar}\right.$ age on $\mathrm{hb}$; Loney and Himmelberg, 1983) gabbroic plutons (Dusel-Bacon and others, 1991; Dusel-Bacon, Brew, and Douglass, in press).

The origin of the metamorphic episode(s) that affected units 82 and 83 is unknown. In the northern and central part of the area made up of these units, the spatial relation of the higher grade metamorphic rocks and Tertiary plutons suggests a genetic link. Unlike the Chugach metamorphic complex (unit 78, and adjacent parts of unit 77), described above, the thermal history of at least some parts of units 82 and 83 appears to be complicated by the occurrence of multiple periods of plutonism (and perhaps metamorphism) in the Tertiary and also probably by a much younger uplift history, as indicated by the exposure of the Miocene plutonic rocks and discordant biotite-hornblende pairs. Another difference between these two metamorphic sequences is the fact that ky, indicative of intermediate-P conditions, occurs at one locality in unit 83, whereas anda, indicative of low-pressure conditions, is present in unit 78.

\section{Retrograde effects in overlying units corresponding with metamorphism and underthrusting of Chugach terrane flysch}

North-directed underthrusting of Chugach terrane flysch beneath the southern margin of the (composite) Peninsular-Wrangellia-Alexander terrane, which is thought to have occurred during latest Cretaceous to early Tertiary time, may be responsible for (1) greenschist-facies retrograde metamorphism $\left(\mathrm{M}_{2}\right)$ of overlying unit 58 (Haley Creek metamorphic assemblage) (Wallace, 1981, 1984; Nokleberg and others, 1989); (2) prehnite-pumpellyite-facies retrograde metamorphism $\left(\mathrm{M}_{2}\right)$ of overlying unit 59 (part of the Strelna metamorphics of Plafker and others, 1989b); and (3) a low-grade overprint in the Jurassic plutons that intrude unit 59 (Dusel-Bacon, Csejtey, and others, in press). Characteristic $\mathrm{M}_{2}$ minerals in unit 59 are pr (which occurs most commonly as lenses that bow apart the cleavage planes of metamorphic and igneous bt, and less commonly as veins), ep, ch, and rare pu or lau (Dusel-Bacon, Csejtey, and others, in press). Calcium-rich fluids which formed veins of $\mathrm{pr}$, and probably played a part in crystallization of $\mathrm{M}_{2}$ phases, may have been derived from the underlying graywackes of the Valdez Group (Chugach terrane flysch). Lower plate rocks belonging to the Valdez Group may underlie unit 59 at a fairly shallow level, as is the case with the correlative Haley Creek metamorphic assemblage (unit 58), where the Valdez Group occurs at a depth of only $1 \mathrm{~km}$ (Page and others, 1986). Fracturing and fluid migration probably occurred during extension of upper plate rocks belonging to the Strelna metamorphics as they were underthrust by rocks of the Valdez Group. A possible analog to the proposed formation of pr in this unit is provided by the study of pr in plutonic and metamorphic rocks of the Salinian block of California. Ross (1976) proposed that hydrous solutions, derived from a "substratum" of Franciscan(?) graywackes, migrated through fractured rocks of the tectonically thinned margin of the Salinian block near the Sur fault zone, causing widespread crystallization of Ca-Al silicates.

\section{Early Tertiary low-arade metamorphism of Prince William and Ghost Rocks terranes}

A weakly metamorphosed and strongly deformed subduction complex of flysch and tholeiite, shown as prehnite-pumpellyite-facies unit 84 and related polymetamorphosed unit 85 , crops out seaward of the slightly older Chugach terrane subduction complex. This complex is separated from the Chugach terrane by the 
landward-dipping Contact fault system. In the northem Gulf of Alaska, units 84 and 85 make up the Orca Group of the Prince William terrane (Tysdal and Case, 1979; Winkler, 1976; Winkler and Plafker, 1981; Helwig and Emmet, 1981). On Kodiak Island, unit 84 constitutes the Ghost Rocks Formation of Byrne (1982) of the Ghost Rocks terrane (Connelly, 1978; Byrne, 1986). The depositional age of the Orca Group is late Paleocene to middle Eocene (Plafker and others, 1985). Eocene fossils are reported from the Ghost Rocks Formation (Connelly, 1978), but the bulk of the formation accumulated during earliest Paleocene time with mélange units including some Late Cretaceous material (Moore and others, 1983). Units 84 and 85 are generally isoclinally folded and include metagraywacke, argillite, metalimestone, greenstone, and mafic schist. Intense localized shearing has produced many zones of tectonic mélange on Kodiak Island (Byrne, 1984) and in the southwestern part of Prince William Sound. In general, rocks of the Orca Group of unit 84 show a gradual increase in metamorphic grade from south to north (Goldfarb and others, 1986).

Low-grade metamorphism and deformation within both the Ghost Rocks and Prince William terranes took place during early Tertiary time and predated, perhaps by very little, the intrusion of the early Tertiary plutons that stitch them to the Chugach terrane. On Kodiak Island, these plutons, dated at $62 \mathrm{Ma}$, contact metamorphosed the Upper Cretaceous and Paleocene Ghost Rocks Formation and cut its structural fabric (Moore and others, 1983). Eocene and younger rocks in the Kodiak Islands are only slightly altered--further supporting a Paleocene metamorphic age for that area (Moore and others, 1983). Intrusion and metamorphism of the upper Paleocene to middle Eocene Orca Group occurred slightly later than did metamorphism of the Ghost Rocks Formation. From Prince William Sound to the east, 53 to 48-Ma plutons crosscut and contact metamomhosed already deformed and weakly metamorphosed rocks of the Orca Group (Winkler and Plafker, 1981; Miller and others, 1984). If the timing of metamorphism parallels that of plutonism, metamorphism began earlier in the west than in the east.

Low-grade metamorphism was probably associated with accretion of the terranes. Asymmetric northdipping south-verging folds, which developed within unit 84 and the adjacent greenschist-facies rocks of the Chugach terrane (unit 77) near the Contact fault zone west of the Copper River, are interpreted as being synaccretionary structures, developed during oblique thrust convergence (Plafker and others, 1986). Similarly, Byrne (1986) proposed that the development of conjugate folds and spaced cleavage within the Ghost Rocks Formation occurred as a result of subhorizontal shortening of the accretionary complex during underthrusting.

East of the Copper River within unit 85, the low-grade mineral assemblages and associated structures, presumed to have formed during accretion, are overprinted by gt-co-bearing, low- $P$, amphibolite-facies assemblages. These higher grade assemblages were produced during the regionally extensive, predominantly thermal, metamomhism that accompanied the intrusion of Eocene plutons in this area of the Prince William and adjacent Chugach terranes (Miller and others, 1984; Sisson and others, 1989). The metamorphic effects of this episode extend across the Contact fault zone and correspond to the $\mathrm{M}_{2}$ episode of unit 78 (Chugach metamorphic complex), as discussed in a previous section.

\section{SOUTHEASTERN ALASKA}

\section{Middle Cambrian to Early Ordovician metamomhism}

The oldest metamorphic episode in southeastern Alaska occurred under dominantly greenschist-facies conditions $\left(M_{1}\right.$ of unit 86 ) on southern Prince of Wales Island (Gehrels and Saleeby, 1987b), in small areas (not shown on sheet 1) on the southern tip of Gravina Island and adjacent islands (Gehrels and others, 1987), and under amphibolite-facies conditions ( $M_{1}$ of unit 87 ) on southern Dall Island to the west (G.E. Gehrels, oral commun., 1987). Both of these units consist of metavolcanic and metasedimentary rocks. They have been described as the Wales Group (Buddington and Chapin, 1929; Herreid and others, 1978; Eberlein and others, 1983) and most recently as the informally designated Wales metamorphic suite (Gehrels and Saleeby, 1987b). Unit 86 consists of greenschist-facies mafic schist, greenstone, pelitic schist, phyllite, and marble, and small areas of amphibolite-facies schist and metaplutonic rocks. Unit 87 contains amphibolite-facies equivalents of unit 86. Preliminary U-Pb ages on zircon indicate Middle and Late Cambrian protolith ages for interlayered metaplutonic bodies, and thus Late Proterozoic and (or) Cambrian protolith ages for the associated metasedimentary and metavolcanic rocks of these two units (Gehrels and Saleeby, 1987b).

In most areas, protolith features are obscured by penetrative metamorphic recrystallization and a high degree of flattening (Gehrels and Saleeby, 1987b). Mineral lineations are common in the amphibolite-facies rocks, and are present locally in mafic schist (Herreid and others, 1978; Eberlein and others, 1983).

A Late Cambrian and Early Ordovician age is indicated for $M_{1}$ metamorphism because: (1) metaplutonic rocks of Middle and (or) Late Cambrian age are metamorphosed and deformed (Gehrels and Saleeby, 1987b), but uppermost Lower and Middle Ordovician strata of unit 88 that occur nearby and probably overlie unit 86 are only weakly metamorphosed and lack the penetrative metamorphic fabric characteristic of unit 86 (Eberlein and others, 1983; Gehrels and Saleeby, 1987b); and (2) rocks from unit 86 yield K-Ar ages of about 
$483 \mathrm{Ma}$ (Turner and others, 1977). This metamorphic episode is part of the Wales orogeny of Gehrels and Saleeby $(1987 a, b)$. Although retrograde metamorphic effects have not been reported for units 86 and 87 , geologic relations indicate that they were probably affected by the same low-grade metamorphic episode during Silurian and earliest Devonian time (shown as $\mathrm{M}_{2}$ ) that is recorded in adjacent unit 88.

\section{Silurian to earliest Devonian low- to medium-arade metamorphism}

A weakly to moderately developed, Silurian to earliest Devonian metamorphic episode is recorded in the prehnite-pumpellyite-facies rocks of unit 88; in the lower greenschist-facies rocks of unit 89; and in the $M_{1}$ episode of the polymetamorphosed greenschist- and locally epidote-amphibolite-facies rocks of unit 90 . Included in these units are basaltic to rhyolitic metavolcanic rocks, metasedimentary rocks, metachert, and metalimestone of late Early Ordovician to Early Silurian protolith age, and quartz dioritic plutons of Middle Ordovician to Early Silurian age (Eberlein and others, 1983; Gehrels and Berg, in press).

The metamorphic grade is lowest on southern Prince of Wales Island and increases westward and eastward. Unit 88 is not penetratively deformed, and relict sedimentary and volcanic textures are widespread. Crosscutting plutonic rocks, also assumed to have been weakly metamorphosed, are locally brecciated. Metamorphism in the westernmost exposure of unit 88 increases southward into semischistose rocks of unit 89. East of Prince of Wales Island, the polymetamorphosed rocks of unit 90 generally are cataclastically deformed and show no pronounced foliation; locally rocks are schistose (Berg and others, 1988; Gehrels and others, 1983). Minor retrogressive metamorphism, apparent in the higher grade rocks of unit 90 , is believed to have occurred during one or more of the Cretaceous metamorphic episodes, described below.

A Silurian to earliest Devonian metamorphic age is indicated for the following reasons: (1) strata of Early Silurian age are metamorphosed but overlying strata of middle Early Devonian age and younger are either unmetamorphosed, as on Prince of Wales Island, or only affected by the Cretaceous metamorphic episode, as on the islands to the east (Gehrels and others, 1983); (2) metamorphosed Silurian rocks of unit 87 are cut by an undeformed latest Silurian to earliest Devonian ( $408 \pm 10 \mathrm{Ma}$ ) pyroxenite (Eberlein and others, 1983; G.E. Gehrels, written commun., 1984); and (3) Late Silurian trondhjemite dikes crosscut the foliation of metadioritic rocks of Late Ordovician to Early Silurian protolith age, but have the same post-metamorphic deformational features as their wallrocks, indicating that the trondhjemite dikes and plutons were intruded before the final deformation that occurred during the latter stages of the episode (Gehrels and others, 1983; G.E. Gehrels, oral commun., 1985). Metamorphism of this unit is considered to have been part of an orogenic event referred to as the Klakas orogeny (Gehrels and others, 1983; Gehrels and Saleeby, 1987b).

\section{Early Cretaceous metamorphism}

Metamorphism in units 95 to 98 was apparently associated with the intrusion of elongate bodies of highly foliated tonalite and diorite of Early Cretaceous age (120-110 Ma; Loney and others, 1967; Decker and Plafker, 1982; Dusel-Bacon and others, 1991; Dusel-Bacon, Brew, and Douglass, in press). These units are included in the Alexander terrane.

Unit 95 crops out near Glacier Bay and on Chichagof Island and consists of a diverse assemblage of amphibolite-facies and hornblende-hornfels facies pelitic and semipelitic schist and gneiss, marble, and amphibolite, and minor amounts of lower grade greenstone and greenschist; protoliths are sedimentary and volcanic rocks of Silurian to Devonian age (Loney and others, 1975; Brew, 1978). On Chichagof Island, rocks are intensely folded and there is a complete gradation in metamorphic textures between hornfels and foliated rocks (Loney and others, 1975). Structural trends in metamorphic rocks parallel those of the Cretaceous plutons. The general parallelism between the foliate fabric of the plutons, pluton wall-rock contacts, and structures in the wall rocks, suggests that plutonism, folding, and thermal and dynamothermal metamorphism all took place as part of a continuum that occurred under roughly the same stress conditions.

Units 96 to 98 crop out on Admiralty Island and the adjacent mainland and form a sequence of metasedimentary, metavolcanic, and metaplutonic rocks that range in grade from prehnite-pumpellyite facies (unit 96), to greenschist (or albite-epidote-hornfels) facies (unit 97), and finally to undifferentiated greenschist (or albite-epidote-hornfels) facies and amphibolite (or hornblende-hornfels) facies (unit 98). Protoliths range in age from Ordovician to Early Cretaceous (references given in Dusel-Bacon and others, 1991, and Dusel-Bacon, Brew, and Douglass, in press). Most medium and higher grade rocks are penetratively deformed. Intrusive rocks of the largest batholith on Admiralty Island are poorly to well foliated, but the trend of the foliation relative to that of the country rocks has not been studied in detail (Lathram and others, 1965). Evidence that metamorphism was associated with late Early Cretaceous plutonism consists of an apparent progressive increase in metamorphic grade toward the plutons, and a merging of contact aureoles with large areas of dynamothermally metamorphosed phyllite, schist, and gneiss of unit 98 (Loney and others, 1967).

The age and origin of metamorphism of greenschist- and, very locally, amphibolite-facies rocks of unit 92 is unknown. This unit crops out northeast of Glacier Bay and is bounded on the east by the Denali fault. 
Protoliths include mafic volcanic rocks, sedimentary rocks, and limestone, and have been correlated with rocks of Silurian to Permian age (MacKevett and others, 1974). Unit 92 also is intruded by a pluton of the belt of 120- to 110-Ma plutons that are thought to have been associated with metamorphism of units 95 to 98 to the south; therefore, metamorphism of unit 92 may have had a similar origin. An alternative and slightly older metamorphic history is suggested by geologic evidence from the apparent continuation of this unit about $100 \mathrm{~km}$ to the northwest in Canada. In that area, regional metamorphism and deformation appear to have occurred between Late Triassic and Early Cretaceous time and may have been associated with latest Jurassic to earliest Cretaceous (150-130 Ma) plutonism (R.B. Campbell and C.J. Dodds, written commun., 1986). This possible metamorphic episode is analogous to that discussed for unit 64 in the previous section (area of southern Alaska between the McKinley and Denali faults and the Border Ranges fault system).

\section{Mid-Cretaceous low-arade metamorphism}

Prehnite-pumpellyite- to lower greenschist-facies metasedimentary rocks, intermediate to mafic metavolcanic rocks, metalimestone, and metachert (unit 100 and related polymetamorphic unit 102) crop out in a 150-km-long southeast-trending belt from Kupreanof Island to Cleveland Peninsula. Protoliths or rocks correlated with the protoliths range in age from Late Triassic to mid-Cretaceous--Albian or Cenomanian (Berg and others, 1972; Brew and others, 1984). Rocks have been weakly metamorphosed (ch-, ac-, and rarely btzone assemblages) and locally are intensely folded and faulted. Metasedimentary rocks are generally poorly foliated, but fine-grained variants have good cleavage. Greenschist and greenstone locally contain abundant relict pyroxene phenocrysts (Brew and others, 1984).

Regional low-grade metamorphism is known to predate the intrusion of Alaskan-type mafic-ultramafic bodies that have yielded K-Ar ages of 110 to $100 \mathrm{Ma}$ (Lanphere and Eberlein, 1966; Clark and Greenwood, 1972; Brew and others, 1984; Douglass and Brew, 1985). The late Early Cretaceous minimum metamorphic age indicated by these dates is close to the Albian or Cenomanian protolith age of the youngest rocks included in this unit. The geographic limits of the area affected by this episode are not known with certainty; they may have extended into the area shown as unit 101, discussed below.

\section{Early Late Cretaceous intermediate-P metamorphism associated with the intrusion of 90-Ma plutons}

Amphibolite-facies pelitic schist, quartzofeldspathic schist and gneiss, amph schist and gneiss, and minor amounts of marble, calc-schist, migmatite, and metaplutonic rocks (Berg and others, 1988; Brew and others, 1984) of unit 103 crop out in the area of Wrangell and Revillagigedo Islands adjacent to and extending some distance from 90-Ma plutons. Protoliths of unit 103 are considered to include Jurassic and (or) Cretaceous flysch, Permian and Triassic limestone, and intrusive rocks of probable Jurassic to Cretaceous age. Rocks are sufficiently recrystallized so that neither the original textures nor the original structures remain.

Kyanite, indicative of intermediate-P metamorphic conditions, is common in the st+gttsil-bearing pelitic schist of unit 103 (Berg and others, 1988; Douglass and Brew, 1985) and in aureoles developed around the 90-Ma plutons that intrude unit 102. In the northern part of unit 103 and within adjacent unit 102, relict anda also has been observed in pelitic schist from the aureoles of 90-Ma plutons (sheet 1). In these areas, relict porphyroblasts of statically formed anda have been replaced by static (radial) ky or in some locations by mineral aggregates of intergrown ky and st (Dusel-Bacon and others, 1991; Dusel-Bacon, Brew, and Douglass, in press). This crystallization sequence of the $\mathrm{Al}_{2} \mathrm{SiO}_{5}$ polymorphs appears to indicate an increase from low- to intermediate-P conditions in the northern part of this unit during intrusion and metamorphism.

Most of the 90-Ma plutons referred to above are of intermediate composition and contain primary gt and epidote; they are part of a plutonic belt that extends from southern Revillagigedo Island north to the vicinity of Haines (Zen and Hammarstrom, 1984a). Sillimanite and ky isograds are located around the large 90-Ma plutons in the areas of Wrangell and northern Revillagigedo Islands, and metamorphic grade increases toward the plutons (Dusel-Bacon and others, 1991; Dusel-Bacon, Brew, and Douglass, in press), providing evidence that metamorphism was associated with plutonism. These plutons (shown as Kg with a "+" overprint on sheet 1) are interpreted as having been emplaced during the waning stages of metamorphism and deformation (Brew and others, 1984; Douglass and Brew, 1985; Berg and others, 1988).

Geothermometric and geobarometric data from two samples of gt-ky schist in the southern part of unit 103 indicate a final equilibration $\mathrm{T}$ and $\mathrm{P}$ of $600^{\circ} \mathrm{C}, 7.5-8.5 \mathrm{~kb}$, and $575-600^{\circ} \mathrm{C}, 8.5-9.2 \mathrm{~kb}$ for mineral rims (M.L. Crawford, written commun., 1983; Dusel-Bacon and others, 1991; Dusel-Bacon, Brew, and Douglass, in press). A similar, moderately high, $\mathrm{P}$ of final crystallization has been proposed for the primary gt- and epidote-bearing 90-Ma plutons that intruded this unit late in, or immediately following, the metamorphic episode. Zen and Hammarstrom (1984b), citing experimental data on the composition of magmatic gt and on the $P$ required to crystallize magmatic epidote, propose that the magma began to crystallize at a minimum $P$ of 13 to $15 \mathrm{~kb}$ (about 40 to $50 \mathrm{~km}$ ) and finally crystallized at about 6 to $10 \mathrm{~kb}$ (about 20 to $30 \mathrm{~km}$ ). The combination of the high- to intermediate-P magmatic and crystallization history inferred for the plutons, and 
the occurrence of relict anda, indicative of low-P conditions (less than $3.8 \mathrm{~kb}$; Holdaway, 1971), in their aureoles in the Wrangell Island area, is indeed problematic.

Greenschist-facies unit 101 crops out south of amphibolite-facies unit 103 in the area of Revillagigedo Island and consists of metasedimentary and metavolcanic rocks, and minor amounts of marble and metaplutonic rocks (Berg and others, 1988). Protolith ages range from Devonian to Early Cretaceous (Berg and others, 1988; Gehrels and others, 1987). On Revillagigedo Island and the peninsula to the northwest, metamorphic foliation dips to the northeast, and the metamorphic sequence is cut by southwest-vergent thrust faults (Berg and others, 1988; Rubin and Saleeby, 1987).

Metamorphism of unit 101 also may have been part of the same thermal episode that culminated in the intrusion of early Late Cretaceous (approximately $90 \mathrm{Ma}$ ) plutons, as was the case for unit 103. This relation is suggested by the observation made by Berg and others (1988) that metamorphic mineral assemblages show an apparent gradational increase in grade from the southwest to the northeast, beginning in the greenschistfacies rocks of unit 101 and continuing into the amphibolite-facies unit 103. An argument against this interpretation is the recent detailed mapping by M.L. Crawford (oral commun., 1988), which indicates an abrupt, rather than gradational, increase in metamorphic grade at the boundary between units 101 and 103. An alternative, but not necessarily mutually exclusive, interpretation is that regional greenschist-facies metamorphism is a higher grade equivalent of the mid-Cretaceous episode that affected unit 100 (DuselBacon and others, 1991; Dusel-Bacon, Brew, and Douglass, in press). This hypothesis is based on an extension of the interpretation of the metamorphic history of unit 100 to the northwest (Brew and others, 1984; Douglass and Brew, 1985) and on similarities noted during a reconnaissance of northern Revillagigedo Island by D.A. Brew (unpub. data, 1983).

$\mathrm{K}$-Ar age determinations on amphibolite- and greenschist-facies rocks on Revillagigedo Island show a decrease in maximum apparent ages northward and eastward (Smith and Diggles, 1981; Berg and others, 1988). ${ }^{40} \mathrm{Ar} /{ }^{39} \mathrm{Ar}$ plateau ages on $\mathrm{hb}$ from plutonic and metamorphic rocks on Revillagigedo Island and from similar rocks to the south in British Columbia, show a similar age pattern, ranging from greater than $90 \mathrm{Ma}$ in the west to about 56 Ma near the eastem boundary of unit 103 (Sutter and Crawford, 1985). Uplift of this block of rocks was greatest and occurred latest in the eastern part of the block. The eastem boundary of the block is spatially related to the Coast Range megalineament (Brew and Ford, 1978)--a topographic, structural, and geophysical feature that appears to have been near the western limit of large-scale regional uplift of southeastern Alaska and adjacent parts of British Columbia beginning in early Tertiary time (Crawford and Hollister, 1982, 1983).

\section{Late Cretaceous to early Tentiary synkinematic metamorphism and plutonism}

An intermediate-P (Barrovian) metamorphic sequence consisting of prehnite-pumpellyite-facies rocks (unit 105), greenschist-facies rocks (unit 106), and amphibolite-facies rocks (unit 107) crops out as an elongate, northwest-trending belt along the mainland of southeastern Alaska from Skagway to the area east of Wrangell Island. The Barrovian sequence increases in metamorphic grade to the northeast (Dusel-Bacon and others, 1991; Dusel-Bacon, Brew, and Douglass, in press, and references contained therein). Protoliths are thought to be clastic sedimentary rocks, mafic to intermediate volcanic, intrusive, and volcanogenic sedimentary rocks, limestone, and chert. Few fossils have been found in these rocks but protolith ages are considered to be Permian, Triassic, and Jurassic to Cretaceous (Brew and Ford, 1984).

An early foliation, presumably formed during either or both of the low-grade episodes recorded in adjacent units 93 and 96, is locally detectable in unit 105 and the lowest grade part of unit 106 (Brew and others, 1984). With increasing metamorphic grade, rocks develop well-defined crenulation cleavage and transposition layering. Higher-grade rocks in unit 106 and all those in unit 107 are well foliated and lineated. Foliation in gneissic rocks is locally anastamosing or lenticular. Mineral isograds marking the first appearance of bt, gt, st, ky, and sil trend north-northwest, generally parallel with elongate quartz dioritic plutons referred to as the tonalite sill by Brew and Ford (1981). It is shown on sheet 1 as the $600-\mathrm{km}$-long synkinematic intrusive unit TKg, just east of the Coast Range megalineament. Isogradic surfaces dip moderately to steeply northeast (Ford and Brew, 1973, 1977a; Brew and Ford, 1977), and hence are inverted. In the area east of Kupreanof Island, isogradic surfaces appear to steepen northeastward toward the Coast Range megalineament (Brew and others, 1984).

Garnet-biotite geothermometry for the sil-zone rocks of unit 107 (Himmelberg and others, 1984) indicates an equilibration T of about $690^{\circ} \mathrm{C}$ (calibration of Thompson, 1976) or $750^{\circ} \mathrm{C}$, (calibration of Ferry and Spear, 1978). The absence of anda and the abundance of ky indicates a minimum equilibration $P$ of about $3.8 \mathrm{~kb}$ (Holdaway, 1971). Preliminary sphalerite geobarometry of three massive-sulphide deposits within the megalineament zone on the mainland east of central Admiralty Island indicates a general $P$ range that is consistent with values of 3.8 to $4.5 \mathrm{~kb}$ at $575^{\circ} \mathrm{C}$, calculated from silicate mineral equilibria of st-zone rocks in the same general area (Stowell, 1985). Geobarometry calculated by several methods indicates a P of 
about $9 \mathrm{~kb}$ for rocks to the north, but the data exhibit large scatter (G.R. Himmelberg, unpub. data, 1987; Brew and others, 1987).

Amphibolite-facies rocks on the mainland east and southeast of Wrangell Island (unit 108) comprise lithologies similar to those in the amphibolite-facies part of the Barrovian metamorphic sequence (unit 107) to the north. Although they occur on strike, they are differentiated on the basis of possible $P$ differences during final equilibration of the rocks. Unit 108 is a heterogeneous complex of migmatite, massive to foliated or gneissic batholiths, and smaller plutons that enclose metamorphic screens and roof pendants of paragneiss (Berg and others, 1988). Protolith ages are not generally known, but those of paragneiss are probably Paleozoic or Mesozoic (Brew and Ford, 1984; Berg and others, 1988) and at least some of those of orthogneiss are Early Cretaceous (Barker and Arth, 1984; Hill, 1984).

Garnet and sil are common constituents of the paragneiss and pelitic schist of unit 108; co occurs locally in the pelitic schist. Intermediate- to low-P conditions are suggested by mineral assemblages, and by thermobarometric data that indicate P-T conditions of 3.5 to $4.5 \mathrm{~kb}$ and $650^{\circ} \mathrm{C}$ (calibration of Ferry and Spear, 1978) for a sample of sil-gt-bt-qz-pl schist in northeastern Ketchikan quadrangle (M.L. Crawford, written commun., 1983; Dusel-Bacon and others, 1991; Dusel-Bacon, Brew, and Douglass, in press). In many areas, paragneiss grades downward and laterally into gneissic granodionite; elsewhere it is in sharp contact with plutonic rocks, or passes gradually into them through a zone of migmatite (Berg and others, 1988). Quartz diorite of the tonalite sill is commonly at least weakly foliated, and in the extreme case, is gneissic. Its foliation generally strikes north or northwest and is parallel to the outcrop trend and to the internal structure of the adjoining metamorphic rocks of unit 108. Much of the quartz diorite also has mylonitic or cataclastic textures, such as undulose quartz and granulated grain boundaries (Berg and others, 1988).

Metamorphism of units 105 to 108 (and $\mathrm{M}_{2}$ of unit 104) is considered to be slightly pre-and synkinematic with the latest Cretaceous and early Tertiary mesozonal intrusion of the tonalite sill. Intrusion of the sill has been dated by U-Pb zircon methods at about 69 and $62 \mathrm{Ma}$ in the north (Gehrels and others, 1984) and at about 58 to $55 \mathrm{Ma}$ in the south (Berg and others, 1988). Evidence for the association of metamorphism and plutonism consists of the increase in metamorphic grade toward the sill; general parallelism between the sill and isograds that define the Barrovian metamorphic sequence; and parallelism of foliation, contacts, and locally developed lineation in the sill with structural elements in the adjacent metamorphic rocks. In the Juneau area, truncation of metamorphic isograds by the sill, and parallelism between foliation in the sill and that in the metamorphosed wallrocks, suggest that intrusion of the sill accompanied a late stage of the regional metamorphism--a stage occurring after the thermal maximum but before the end of penetrative deformation (Ford and Brew, 1977b). Epizonal plutons (Tg) intruded the eastern part of the amphibolite-facies units during Eocene time. These Eocene plutons are surrounded by low-P high-T metamorphic rocks and by migmatites. The original eastern limit of the Barrovian metamorphism is obscured by the Eocene intrusions, but limited evidence indicates that the low-P metamorphism around the Eocene plutons was superimposed over the previous intermediate-P metamorphism.

A P-T-time path has been determined for the plutonic and metamorphic sequence that crops out near Prince Rupert, British Columbia, across the international boundary from unit 108. Many aspects of that path may also apply to the metamorphic history of unit 108 and perhaps also of units 105 to 107 . Near Prince Rupert, metamorphic reactions, thermobarometric data, and isotopic data indicate that rocks correlative with those of unit 108 were uplifted and eroded at a rate of about $1 \mathrm{~mm} / \mathrm{yr}$ between about 60 and $48 \mathrm{Ma}$, beginning at a depth of about $20 \mathrm{~km}$ and terminating at about $5 \mathrm{~km}$ (Hollister, 1982; revised in Crawford and others, 1987). The emplacement of the elongate 60-Ma Quotoon pluton, which is the continuation of the Alaskan tonalite sill, apparently occurred at deep levels during the early stages of uplift. Emplacement of intermediate and felsic plutons along the easterm margin of the complex occurred at high levels during the end stages of uplift. According to the Canadian work, metamorphism continued throughout the period of uplift under evolving P-T conditions (Hollister, 1982; Crawford and Hollister, 1982, 1983). Because of similarities in style and conditions of metamorphism between rocks west of the megalineament in British Columbia (correlative with unit 101) and early metamorphic relicts found in rocks east of the megalineament (correlative with unit 108), Crawford and Hollister $(1982,1983)$ suggest that high-grade rocks east of the megalineament were also metamorphosed during the episode associated with the intrusion of the 90-Ma plutons, discussed above. The high-grade crustal block east of the megalineament is thought to have remained at depth until it was displaced by rapid vertical uplift as a result of the weakening of the crust by anatexis and the development of melt-lubricated shear zones--particularly the one represented by the tonalite sill, along which rapid vertical movement was concentrated (Hollister and Crawford, 1986; Crawford and others, 1987).

The tectonic environment of the widespread plutono-metamorphic episode that occurred along the western edge of the Coast Mountains in early Late Cretaceous and early Tertiary time was dominated by crustal thickening due to the accretion of an outboard terrane to the west. Monger and others $(1982,1983)$ proposed that the plutono-metamorphic belt of the Coast Mountains of southeastern Alaska and British Columbia developed as a welt resulting from the accretion of the amalgamated Wrangellia and Alexander 
terranes against the previously accreted Stikinia and other terranes in Cretaceous and Tertiary time. Brew and Ford (1983) interpret the stratigraphic and paleomagnetic evidence to suggest that the Alexander and Stikinia terranes are one and the same and that a rift developed in the megaterrane as it migrated northward. According to their model, that rift was filled with the flysch and volcanic rocks of the Gravina belt (Berg and others, 1972) during Late Jurassic and Early Cretaceous time. They propose that the plutono-metamorphic belt formed as a result of the closure of the rift and the resultant crustal thickening during accretion of the Chugach terrane--a terrane that lies to the west and southwest of the Alexander and Wrangellia terranes.

Workers in the southern extension of this metamorphic belt near Prince Rupert, British Columbia, concur with the terrane accretion model of Monger and others (1982). They propose that the crustal thickening resulted from west-directed tectonic stacking of crustal slabs along east-dipping thrusts. In places the thrusts were possibly lubricated by the intrusion of melt (parent magma of intermediate epidote-bearing plutons and sills) generated at the base of the crust (Hollister and Crawford, 1986; Crawford and others, 1987). These thrust faults, which were synchronous with 100- to 90-Ma plutonism near Prince Rupert, may be correlative with thrusts identified on Revillagigedo Island in Alaska (M.L. Crawford, oral commun.,1987).

\section{ACKNOWLEDGMENTS}

This metamorphic compilation and summary would not have been possible had it not been for the willingness of numerous colleagues from the U.S. Geological Survey, the State of Alaska's Division of Geological and Geophysical Surveys, and several universities to contribute their time, thoughts, and unpublished data. I am particularly indebted to S.E. Box, D.A. Brew, H.L. Foster, George Plafker, and A.B. Till. Drafting and technical assistance were provided by S.L. Douglass and E.O. Doyle. J.Y. Bradshaw and S.M. Roeske made valuable suggestions to improve the original manuscript. Finally, I wish to especially thank Jan Detterman for her invaluable and exceedingly patient editing of the various, and evolving formats of the metamorphic facies studies of Alaska. 


\section{REFERENCES CITED}

Aleinikoff, J.N., Dusel-Bacon, Cynthia, and Foster, H.L., 1984a, Uranium-lead isotopic ages of zircon from sillimanite gneiss and implications for Paleozoic metamorphism, Big Delta quadrangle, east-central Alaska, in Coonrad, W.L., and Elliott, R.L., eds., The United States Geological Survey in Alaska: Accomplishments during 1981: U.S. Geological Survey Circular 868, p. 45-48. 1986, Geochronology of augen gneiss and related rocks, Yukon-Tanana terrane, east-central Alaska: Geological Society of America Bulletin, v. 97, no. 5, p. 626-637. 1987, Lead isotopic fingerprinting of tectono-stratigraphic terranes, east-central Alaska: Canadian Journal of Earth Sciences, v. 24, p. 2089-2098.

Aleinikoff, J.N., Foster, H.L., Nokleberg, W.J., and Dusel-Bacon, Cynthia, 1984b, Isotopic evidence from detrital zircons for early Proterozoic crustal material, east-central Alaska, in Coonrad, W.L., and Elliott, R.L., eds., The United States Geological Survey in Alaska: Accomplishments during 1981: U.S. Geological Survey Circular 868, p. 43-45.

Aleinikoff, J.N., and Nokleberg, W.J., 1985, Age of Devonian igneous-arc terranes in the northern Mount Hayes quadrangle, eastern Alaska Range, Alaska, in Bartsch-Winkler, Susan, ed., The United States Geological Survey in Alaska: Accomplishments during 1984: U.S. Geological Survey Circular 967, p. 44-49.

Aleinikoff, J.N., Nokleberg, W.J., and Herzon, P.L., 1982, Age of intrusion and metamorphism of the East Susitna batholith, Mount Hayes B-6 quadrangle, eastern Alaska Range, Alaska, in Coonrad, W.L., ed., The United States Geological Survey in Alaska: Accomplishments during 1980: U.S. Geological Survey Circular 844, p. 97-100.

Aleinikoff, J.N., Plafker, George, and Nokleberg, W.J., 1988, Middle Pennsylvanian plutonic rocks along the southern margin of the Wrangellia terrane, in Galloway, J.P., and Hamilton, T.D., eds., Geologic studies in Alaska by the U.S. Geological Survey during 1987: U.S. Geological Survey Circular 1016, p. 110113.

Armstrong, R.L., Harakal, J.E., Forbes, R.B., Evans, B.W., and Thurston, S.P., 1986, Rb-Sr and K-Ar study of metamorphic rocks of the Seward Peninsula and southern Brooks Range, Alaska: Geological Society of America Memoir 164, p. 185-203.

Bacon, C.R., Foster, H.L., and Smith, J.G., 1990, Rhyolitic calderas of the Yukon-Tanana terrane, east central Alaska: Volcanic remnants of a mid-Cretaceous magmatic arc: Journal of Geophysical Research, v. 95, no. B13, p. 21,451-21,461.

Barker, Fred, and Arth, J.G., 1984, Preliminary results, Central Gneiss Complex of the Coast Range batholith, southeastern Alaska: The roots of a high-K, calc-alkaline arc?: Physics of the Earth and Planetary Interiors, v. 35, p. 191-198.

Barker, Fred, McLellan, E.L., and Plafker, George, 1985, Partial melting of amphibolite to trondhjemite at Nunatak Fiord, St. Elias Mountains, Alaska: Geological Society of America Abstracts with Programs, v. 17, no. 7, p. 518-519.

Barker, F., and Stem, T.W., 1986, An arc-root complex of Wrangellia, eastern Alaska Range: Geological Society of America Abstracts with Programs, v. 18, no. 6, p. 534.

Beard, J.S., and Barker, Fred, 1989, Petrology and tectonic significance of gabbros, tonalites, shoshonites, and anorthosites in a late Paleozoic arc-root complex in the Wrangellia terrane, southern Alaska: Joumal of Geology, v. 97, no. 6, p.667-683.

Berg, H.C., Elliott, R.L., and Koch, R.D., 1988, Geologic map of the Ketchikan and Prince Rupert quadrangles, southeastern Alaska: U.S. Geological Survey Miscellaneous Investigations Series Map I1807, scale 1:250,000.

Berg, H.C., Jones, D.L., and Richter, D.H., 1972, Gravina-Nutzotin belt--tectonic significance of an upper Mesozoic sedimentary and volcanic sequence in southern and southeastern Alaska, in Geological Survey research 1972: U.S. Geological Survey Professional Paper 800-D, p. D1-D24.

Boak, J.L., Turner, D.L., Wallace, W.K., and Moore, T.E., 1985, K-Ar ages of allochthonous mafic and ultramafic complexes and their metamorphic aureoles, western Brooks Range, Alaska: American Association of Petroleum Geologists Bulletin, v. 69, no.4, p. 656-657.

Box, S.E., 1985a, Early Cretaceous orogenic belt in northwestern Alaska: Internal organization, lateral extent, and tectonic interpretation, in Howell, D.G., ed., Tectonostratigraphic terranes of the CircumPacific region: Circum-Pacific Council for Energy and Mineral Resources, Earth Science Series, no. 1 (American Association of Petroleum Geologists bookstore, Tulsa, Oklahoma), p.137-145. 1985b, Geologic setting of high-pressure metamorphic rocks, Cape Newenham area, southwestern Alaska, in Bartsch-Winkler, Susan, ed., The United States Geological Survey in Alaska: Accomplishments during 1984: U.S. Geological Survey Circular 967, p. 37-42. 
1985c, Terrane analysis, northern Bristol Bay region, southwestern Alaska, in Bartsch-Winkler, Susan, ed., The United States Geological Survey in Alaska: Accomplishments during 1984: U.S. Geological Survey Circular 967, p. 32-37.

1987, Late Cretaceous or younger southwest-directed extensional faulting: Cosmos Hills, Brooks Range, Alaska: Geological Society of America Abstracts with Programs, v. 19, no. 6, p. 361.

Box, S.E., and Murphy, J.M., 1987, Late Mesozoic structural and stratigraphic framework, eastem Bethel quadrangle, southwestern Alaska, in Hamilton, T.D., and Galloway, J.P., eds., Geologic Studies in Alaska by the U.S. Geological Survey during 1986: U.S. Geological Survey Circular 998, p. 78-82.

Brew, D.A., 1978, Geology, in Chap. B, Geology, geophysics, and geochemistry, in Brew, D.A., Johnson, B.R., Grybeck, Donald, Griscom, Andrew, Barnes, D.F., Kimball, A.L., Still, J.C., and Rataj, J.L., Mineral resources of the Glacier Bay National Monument Wildemess Study Area, Alaska: U.S. Geological Survey Open-File Report 78-494, p. B1-B21, pl. 1A, scale 1:125,000.

Brew, D.A., and Ford, A.B., 1977, Preliminary geologic and metamorphic-isograd map of the Juneau B-1 quadrangle, Alaska: U.S. Geological Survey Miscellaneous Field Studies Map MF-846, scale 1:31,680. 1978, Megalineament in southeastern Alaska marks southwest edge of Coast Range batholithic complex: Canadian Joumal of Earth Sciences, v. 15, no. 11, p. 1763-1772.

1981, The Coast plutonic complex sill, southeastem Alaska, in Albert, N.R.D., and Hudson, Travis, eds., The United States Geological Survey in Alaska: Accomplishments during 1979: U.S. Geological Survey Circular 823-B, p. B96-B99.

1983, Comment on Monger, J.W.H., Price, R.A., and Templeman-Kluit, D.J., 1982, Tectonic accretion and the origin of the two major metamorphic and plutonic welts in the Canadian Cordillera: Geology, $v$. 11 , no. 7, p. 427-428.

1984, The northern Coast plutonic-metamorphic complex, southeastern Alaska and northwestern British Columbia, in Coonrad, W.L., and Elliott, eds., The United States Geological Survey in Alaska: Accomplishments during 1981: U.S. Geological Survey Circular 868, p. 120-124.

Brew, D.A., Ford, A.B., and Himmelberg, G.R., 1987, Late Cretaceous sedimentation, volcanism, plutonism, metamorphism and deformation in the northem Cordillera, southeastern Alaska: Geological Society of America, Abstracts with Programs, v. 19, no. 7, p. 600.

Brew, D.A., Karl, S.M., and Miller, J.W., 1988, Megafossils (Buchia) indicate Late Jurassic age for part of Kelp Bay Group on Baranof Island, southeastem Alaska, in Galloway, J.P., and Hamilton, T.D., eds., Geologic studies in Alaska by the U.S. Geological Survey during 1987: U.S. Geological Survey Circular 1016, p. 147-149.

Brew, D.A., and Morrell, R.P., 1979, Correlation of the Sitka Graywacke, unnamed rocks in the Fainweather Range, and Valdez Group, southeastem and south-central Alaska, in Johnson, K.M., and Williams, J.R., eds., The United States Geological Survey in Alaska: Accomplishments during 1978: U.S. Geological Survey Circular 804-B, p. B123-B125.

Brew, D.A., Ovenshine, A.T., Karl, S.M., and Hunt, S.J., 1984, Preliminary reconnaissance geologic map of the Petersburg and parts of the Port Alexander and Sumdum 1:250,000 quadrangles, southeastern Alaska: U.S. Geological Survey Open-File Report 84-405, 43 p., scale 1:250,000, 2 sheets.

Brown, E.H., and Forbes, R.B., 1984, Paragenesis and regional significance of eclogitic rocks from the Fairbanks District, Alaska: Geological Society of America Abstracts with Programs, v. 16, no. 5, p.272. 1986, Phase petrology of eclogitic rocks in the Fairbanks District, Alaska, in Evans, B.W., and Brown, E.H., eds., Blueschists and eclogites: Geological Society of America Memoir 164, p. 155-167.

Buddington, A.F., and Chapin, Theodore, 1929, Geology and mineral deposits of southeastern Alaska: U.S. Geological Survey Bulletin 800, 398 p.

Bundtzen, T.K., 1981, Geology and mineral deposits of the Kantishna Hills, Mt. McKinley quadrangle, Alaska: Fairbanks, University of Alaska, M.S. thesis, 237 p.

Bundtzen, T.K., and Turner, D.L., 1979, Geochronology of metamorphic and igneous rocks in the Kantishna Hills, Mount McKinley quadrangle, Alaska: Short notes on Alaskan geology--1978, Alaska Division of Geological and Geophysical Surveys, Geologic Report 61, p. 25-30.

Burns, L.E., 1985, The Border Ranges ultramafic and mafic complex, south-central Alaska: cumulate fractionates of island-arc volcanics: Canadian Journal of Earth Sciences, v. 22, p. 1020-1038.

Byrne, T., 1982, Structural geology of coherent terranes in the Ghost Rocks Formation, Kodiak Islands, Alaska, in Leggett, J.K., ed., Trench and forarc sedimentation and tectonics: Geological Society of London Special Paper.

1984, Early deformation in melange terranes of the Ghost Rocks Formation, Kodiak Islands, Alaska in Melanges: Their nature, origin, and significance: Geological Society of America Special Paper 198, p. 21-51. 1986, Eocene underplating along the Kodiak Shelf, Alaska: Implications and regional correlations: Tectonics, v. 5, no. 3, p. 403-421. 
Campbell, R.B., and Dodds, C.J., 1978, Operation Saint Elias, Yukon Territory, in Current Research, Part A: Geological Survey of Canada, Paper 78-1A, p. 35-41.

Carden, J.R., 1978, The comparative petrology of blueschists and greenschists in the Brooks Range and Kodiak-Seldovia schist belts: Fairbanks, Alaska, University of Alaska, Ph.D. dissertation, 242 p.

Carden, J.R., Connelly, William, Forbes, R.B., and Turner, D.L., 1977, Blueschists of the Kodiak Islands, Alaska: An extension of the Seldovia schist terrane: Geology, v. 5, no. 9, p. 529-533.

Carden, J.R., and Decker, J.E., 1977, Tectonic significance of the Knik River schist terrane, south-central Alaska: Alaska Division of Geological and Geophysical Surveys Geologic Report 55, p. 7-9.

Carlson, Christine, 1985, Large-scale south-dipping, low-angle normal faults in the southern Brooks Range, Alaska: Eos, Transactions, American Geophysical Union, v. 66, no. 46, p. 1074.

Carlson, Christine, and Wallace, W.K., 1983, The Tlikakila complex, a disnupted terrane in the southwestem Alaska Range: Geological Society of America Abstracts with Programs, v. 15, no. 5, p. 406.

Clark, A.L., and Greenwood, W.R., 1972, Petrographic evidence of volume increase related to serpentinization, Union Bay, Alaska: U.S. Geological Survey Professional Paper 800-C, p. C21-C27.

Clark, S.H.B., 1973, The McHugh Complex of south-central Alaska: U.S. Geological Survey Bulletin 1372-D, p. D1-D11.

Coleman, R.G., Lee, D.E., Beatty, L.B., and Brannock, W.W., 1965, Eclogites and eclogites: Their differences and similarities: Geological Society of America Bulletin, v. 76, p. 483-508.

Connelly, William, 1978, Uyak Complex, Kodiak Islands, Alaska: A Cretaceous subduction complex: Geological Society of America Bulletin, v. 89, no. 5, p. 755-769.

Cowan, D.S., and Boss, R.F., 1978, Tectonic framework of the southwestern Kenai Peninsula, Alaska: Geological Society of America Bulletin, v. 89, no. 1, p. 155-158.

Crawford, M.L., and Hollister, L.S., 1982, Contrast of metamorphic and structural histories across the Work Channel lineament, Coast Plutonic Complex, British Columbia: Journal of Geophysical Research, v. 87, no. B5, p. 3849-3860.

1983, Correction to "Contrast of metamorphic and structural histories across the Work Channel lineament, Coast Plutonic Complex, British Columbia": Journal of Geophysical Research, v. 88, no. B12, p. $10,645-10,646$.

Crawford, M.L., Hollister, L.S., and Woodsworth, G.J., 1987, Crustal deformation and regional metamorphism across a terrane boundary, Coast Plutonic Complex, British Columbia: Tectonics, v. 6, no. 3, p. 343361.

Csejtey, Béla, Jr., Cox, D.P., and Evarts, R.C., 1982, The Cenozoic Denali fault system and the Cretaceous accretionary development of southern Alaska: Journal of Geophysical Research, v. 87, no. B5, p. 37413754.

Csejtey, Béla, Jr., Mullen, M.W., Cox, D.P., Gilbert, W.G., Yeend, W.E., Smith, T.E., Tumer, D.L., Wahrhaftig, Clyde, Craddock, Campbell, Brewer, W.M., Sherwood, K.W., Hickman, R.G., Stricker, G.D., St. Aubin, D.R., and Goerz, D.J., III, 1986, Geology and geochronology of the Healy quadrangle, Alaska: U.S. Geological Survey Open-File Report 86-396, 96 p., scale 1:250,000, 4 pls.

Csejtey, Béla, Jr., Nelson, W.H., Jones, D.L., Silberling, N.J., Dean, R.M., Morris, M.S., Lanphere, M.A., Smith, J.G., and Silberman, M.L., 1978, Reconnaissance geologic map and geochronology, Talkeetna Mountains quadrangle, northern part of Anchorage quadrangle, and southwest corner of Healy quadrangle, Alaska: U.S. Geological Survey Open-File Report 78-558-A, 60 p., scale 1:250,000.

Cushing, G.W., Foster, H.L., Harrison, T.M., and Laird, Jo, 1984, Possible Mesozoic accretion in the eastern Yukon-Tanana Upland, Alaska: Geological Society of America Abstracts with Programs, v. 16, no. 6, p. 481.

Decker, J.E., Jr., 1980, Geology of a Cretaceous subduction complex, western Chichagof Island, southeastern Alaska: Stanford, Calif., Stanford University, Ph.D. dissertation, 135 p.

Decker, J.E., and Plafker, George, 1982, Correlation of rocks in the Tarr Inlet suture zone with the Kelp Bay Group, in Coonrad, W.L., ed., The United States Geological Survey in Alaska: Accomplishments during 1980: U.S. Geological Survey Circular 844, p. 119-123.

Decker, J.E., Wilson, F.H., and Turner, D.L., 1980, Mid-Cretaceous subduction event in southeastern Alaska: Geological Society of America Abstracts with Programs, v. 12, no. 3, p. 103.

Detterman, R.L., and Reed, B.L., 1980, Stratigraphy, structure, and economic geology of the Illiamna quadrangle, Alaska: U.S. Geological Survey Bulletin 1368-B, scale 1;250,000, p. B28-B32.

Dickinson, W.R., and Snyder, W.S., 1979, Geometry of subducted slabs related to the San Andreas transform: Journal of Geology, v. 87, p. 609-627.

Dillon, J.T., 1987, Latest Cretaceous-earliest Tertiary metamorphism in the northeastern Brooks Range, Alaska: Geological Society of America Abstracts with Programs, v. 19, no. 6, p. 373.

Dillon, J.T., and Bakke, A.A., 1987, Evidence for Devonian age of the Okpilak batholith, northeastern Brooks Range, Alaska: Geological Society of America Abstracts with Programs, v. 19, no. 6, p. 373. 
Dillon, J.T., Brosgé, W.P., and Dutro, J.T., Jr., 1986, Generalized geologic map of the Wiseman quadrangle, Alaska: U.S. Geological Survey Open-File Report OF-86-219, scale 1:250,000.

Dillon, J.T., Patton, W.W., Jr., Mukasa, S.B., Tilton, G.R., Blum, Joel, and Moll, E.J., 1985, New radiometric evidence for the age and thermal history of the metamorphic rocks of the Ruby and Nixon Fork terranes, west-central Alaska, in Bartsch-Winkler, Susan, and Reed, K.M., eds., The United States Geological Survey in Alaska: Accomplishments during 1983: U.S. Geological Survey Circular 945, p. 13-18.

Dillon, J.T., Pessel, G.H., Chen, J.H., and Veach, N.C., 1980, Middle Paleozoic magmatism and orogenesis in the Brooks Range, Alaska: Geology, v. 8, p. 338-343.

Dillon, J.T., Pessel, G.H., Lueck, Larry, and Hamilton, W.B., 1987, Geologic map of the Wiseman A-4 quadrangle: Alaska Division of Geological and Geophysical Surveys Professional Report 87, scale $1: 63,360,2$ sheets.

Dillon, J.T., and Smiley, C.J., 1984, Clasts from the Early Cretaceous Brooks Range orogen in Albian to Cenomanian molasse deposits of the northern Koyukuk basin, Alaska: Geological Society of America Abstracts with Programs, v. 16, p. 279.

Dodds, C.J., and Campbell, R.B., 1988, Potassium-argon ages of mainly intrusive rocks in the Saint Elias Mountains, Yukon and British Columbia: Geological Survey of Canada Paper 87-16, 43 p.

Douglass, S.L., and Brew, D.A., 1985, Polymetamorphism in the eastern part of the Petersburg map area, southeastern Alaska, in Bartsch-Winkler, Susan, ed., The United States Geological Survey in Alaska: Accomplishments during 1985: U.S. Geological Survey Circular 967, p. 89-92.

Dover, J.H., and Miyaoka, R.T., 1985a, Major rock packages of the Ray Mountains, Tanana and Bettles quadrangles, in Bartsch-Winkler, Susan, and Reed, K.M., eds., The United States Geological Survey in Alaska: Accomplishments during 1983: U.S. Geological Survey Circular 945, p. 32-36. 1985b, Metamorphic rocks of the Ray Mountains --preliminary structural analysis and regional tectonic implications, in Bartsch-Winkler, Susan, and Reed, K.M., eds., The United States Geological Survey in Alaska: Accomplishments during 1983: U.S. Geological Survey Circular 945, p. 36-38.

Duke, N.A., Nauman, C.R., and Newkirk, S.R., 1988, Evidence for Late-Cretaceous extensional uplift of the Yukon-Tanana crystalline terrane, eastern Alaska Range: Geological Society of America Abstracts with Programs, v. 20, no. 7, p. A112.

Dusel-Bacon, Cynthia, in press, Map and table showing metamorphic rocks of Alaska, in Plafker, George, and Berg, H.C., eds., The Geology of Alaska: Boulder, Colorado, Geological Society of America, The Geology of North America, v. G1, Plate 4, scale 1:2,500,000, 2 sheets. . in press, a, Metamorphic history of Alaska, in Plafker, George, Jones, D.L., and Berg, H.C., eds., The Geology of Alaska: Boulder, Colorado, Geological Society of America, The Geology of North America, v. G1, 80 ms p., 3 figs., 2 tables.

Dusel-Bacon, Cynthia, and Aleinikoff, J.N., 1985, Petrology and tectonic significance of augen gneiss from a belt of Mississippian granitoids in the Yukon-Tanana terrane, east-central Alaska: Geological Society of America Bulletin, v. 96, no. 4, p. 411-425.

Dusel-Bacon, Cynthia, Brew, D.A., and Douglass, S.L., 1991, Metamorphic facies map of southeastern Alaska--Distribution, facies, and ages of regionally metamorphosed rocks: U.S. Geological Survey Open-File Report 91-29, 46 p., 2 sheets.

Dusel-Bacon, Cynthia, Brew, D.A., and Douglass, S.L., in press, Metamorphic facies map of southeastem Alaska--Distribution, facies, and ages of regionally metamorphosed rocks: U.S. Geological Survey Professional Paper 1497-D, 46 ms p., 2 pls.

Dusel-Bacon, Cynthia, Brosgé, W.P., Till, A.B., Fitch, M.R., Mayfield, C.F., Reiser, H.N., and Miller, T.P., 1989, Distribution, facies, ages, and proposed tectonic associations of regionally metamorphosed rocks in northern Alaska: U.S. Geological Survey Professional Paper 1497-A, 44 p., 2 pls.

Dusel-Bacon, Cynthia, Csejtey, Béla, Foster, H.L., Doyle, E.O., Nokleberg, W.J., and Plafker, George, in press, Distribution, facies, ages, and proposed tectonic associations of regionally metamorphosed rocks in east- and south-central Alaska: U.S. Geological Survey Professional Paper 1497-C, 100 ms p., 2 pls.

Dusel-Bacon, Cynthia, Doyle, E.O., and Box, S.E., in press, Distribution, facies, ages, and proposed tectonic associations of regionally metamorphosed rocks in southwestern Alaska and the Alaska Peninsula: U.S. Geological Survey Professional Paper 1497-B, 42 ms p., 2 pls.

Dusel-Bacon, Cynthia, and Foster, H.L., 1983, A sillimanite gneiss dome in the Yukon crystalline terrane, east-central Alaska: Petrography and garnet-biotite geothermometry: U.S. Geological Survey Professional Paper 1170E, 25 p.

Eberlein, G.D., Churkin, Michael, Jr., Carter, Claire, Berg, H.C., and Ovenshine, A.T., 1983, Geology of the Craig quadrangle, Alaska: U.S. Geological Survey Open-File Report 83-91, 26 p., scale 1:250,000.

Engebretsen, D.C., Cox, Allen, and Gordon, R.G., 1985, Relative motions between oceanic and continental plates in the Pacific basin, Geological Society of America Special Paper 206, 59 p. 
Epstein, A.G., Epstein, J.B., and Harris, L.D., 1977, Conodont Color Alteration--an index to organic metamorphism: U.S. Geological Survey Professional Paper 995, 27 p.

Erdmer, Phillipe, and Armstrong, R.L.,1988, Permo-Triassic isotopic dates for blueschist, Ross River area, Yukon: Canada, Exploration and Geological Services Division, Yukon Indian and Northern Affairs, Yukon Geology, p. 33-36.

Erdmer, Phillipe, and Helmstaedt, Herwart, 1983, Eclogite from central Yukon: a record of subduction at the western margin of ancient North America: Canadian Journal of Earth Sciences, v. 20, p. 1389-1408.

Evans, B.W., and Brown, E.H., 1987, Reply on blueschists and eclogites: Geology, v. 15, no. 8, p. 773-775.

Evans, B.W., Patrick, B.E., and Irving, A.J., 1987, Compositional control of blueschist/greenschist and genesis of Seward Peninsula metabasites: Geological Society of America Abstracts with Programs, v. 19 , no. 6 , p. 375.

Ferry, J.M., and Spear, F.S., 1978, Experimental calibration of the partitioning of $\mathrm{Fe}$ and $\mathrm{Mg}$ between biotite and gamet: Contributions to Mineralogy and Petrology, v. 66, no. 2, p. 113-117.

Forbes, R.B., Evans, B.W., and Thurston, S.P., 1984, Regional progressive high-pressure metamorphism, Seward Peninsula, Alaska: Journal of Metamorphic Geology, v. 2, p. 43-54.

Forbes, R.B., and Lanphere, M.A., 1973, Tectonic significance of mineral ages of blueschists near Seldovia, Alaska: Journal of Geophysical Research, v. 78, no. 8, p. 1383-1386.

Forbes, R.B., and Weber, F.R., 1982, Bedrock geologic map of the Fairbanks mining district, Alaska: Alaska Division of Geological and Geophysical Surveys Open-File Report AOF-170.

Ford, A.B., and Brew, D.A., 1973, Preliminary geologic and metamorphic-isograd map of the Juneau B-2 quadrangle, Alaska: U.S. Geological Survey Miscellaneous Field Studies Map MF-527, scale 1:31,680. 1977a, Preliminary geologic and metamorphic-isograd map of the northern parts of the Juneau A-1 and A-2 quadrangles, Alaska: U.S. Geological Survey Miscellaneous Field Studies Map MF-847, scale $1: 31,680$.

1977b, Truncation of regional metamorphic zonation pattern of the Juneau, Alaska, area by the Coast Range batholith, in Johnson, K.M., ed., The United States Geological Survey in Alaska: Accomplishments during 1976: U.S. Geological Survey Circular 751-B, p. B85-B87.

Foster, H.L., Cushing, G.W., Keith, T.E.C., and Laird, Jo, 1985, Early Mesozoic tectonic history of the Boundary area, east-central Alaska: Geophysical Research Letters, v. 12, no. 9, p. 553-556.

Foster, H.L., Keith, T.E.C., and Menzie, W.D., 1987, Geology of east-central Alaska: U.S. Geological Survey Open-File Report 87-188, 59 p.

Foster, H.L., Laird, Jo, Keith, T.E.C., Cushing, G.W., and Menzie, W.D., 1983, Preliminary geologic map of the Circle quadrangle, Alaska: U.S. Geological Survey Open-File Report 83-170-A, 30 p., scale $1: 250,000$.

Franz, G., and Althaus, E.K., 1977, The stability relations of paragenesis paragonite-zoisite-quartz: Stuttgart, Federal Republic of Germany, Neues Jahrbuch für Mineralogie Abhandlungen, v. 130, p. 159-167.

Gardner, M.C., Bergman, S.C., MacKevett, E.M., Jr., Plafker, George, Campbell, R.C., Cushing, C.J., and McClelland, W.D., 1988, Pennsylvanian pluton stitching of Wrangellia and the Alexander terrane, Wrangell Mountains, Alaska: Geology, v. 16, no. 11, p. 967-971.

Gardner, M.C., MacKevett, E.M., Jr., and McClelland, W.D., 1986, The Chitina fault system of southern Alaska--an Early Cretaceous collisional suture zone: Geological Society of America Abstracts with Programs, v. 18, p. 108.

Gehrels, G.E., and Berg, H.C., in press, Geologic map of southeastern Alaska: U.S. Geological Survey Miscellaneous Investigations Series Map 1-1867, scale 1:600,000.

Gehrels, G.E., Brew, D.A., and Saleeby, J.B., 1984, Progress report on U/Pb (zircon) geochronologic studies in the Coast plutonic-metamorphic complex, east of Juneau, southeastern Alaska, in Reed, K.M., and Bartsch-Winkler, Susan, eds., The United States Geological Survey in Alaska: Accomplishments during 1982: U.S. Geological Survey Circular 939, p. 100-102.

Gehrels, G.E., and Saleeby, J.B., 1987a, Geologic framework, tectonic evolution, and displacement history of the Alexander terrane: Tectonics, v. 6, no. 2, p. 151-173. 1987b, Geology of southern Prince of Wales Island, southeastern Alaska: Geological Society of America Bulletin, v. 98, p. 123-137.

Gehrels, G.E., Saleeby, J.B., and Berg, H.C., 1983, Preliminary description of the Klakas orogeny in the southern Alexander terrane, southeastern Alaska, in Stevens, C.H., ed., Pre-Jurassic rocks in western North American suspect terranes: Pacific Section, Society of Economic Paleontologists and Mineralogists, p. 131-141. 1987, Geology of Annette, Gravina, and Duke Islands, southeastern Alaska: Canadian Journal of Earth Sciences, v. 24, p. 866-881.

Gemuts, I., Puchner, C.C., and Steffel, C.I., 1983, Regional geology and tectonic history of westem Alaska: Journal of the Alaska Geological Society, v. 3, p. 67-86. 
Gilbert, W.G., Wiltse, M.A., Carden, J.R., Forbes, R.B., and Hackett, S.W., 1977, Geology of Ruby Ridge, southwestern Brooks Range, Alaska: Alaska Division of Geological and Geophysical Surveys Geologic Report 58, $16 \mathrm{p}$.

Glassley, W.F., and Cowan, D.S., 1975, Metamorphic history of Franciscan greenstone, blueschist, and eclogite: Eos, Transactions, American Geophysical Union, v. 56, no. 12, p. 1081.

Goldfarb, R.J., Leach, D.L., Miller, M.L., and Pickthorn, W.J., 1986, Geology, metamorphic setting, and genetic constraints of epigenetic lode-gold mineralization within the Cretaceous Valdez Group, southcentral Alaska, in Turbidite-hosted gold deposits, Keppie, J.D., Boyle, R.W., and Haynes, S.J., eds: Geological Association of Canada Special Paper 32, p. 93-113.

Gottschalk, R.R., 1987, Structural and petrologic evolution of the southem Brooks Range near Wiseman, Alaska: Rice University, Houston, Texas, Ph.D. dissertation, 263 p.

Gottschalk, R.R., and Oldow, J.S., 1988, Low-angle normal faults in the south-central Brooks Range fold and thrust belt, Alaska: Geology, v. 16, no. 5, p. 395-399.

Grantz, Arthur, 1966, Strike-slip faults of Alaska: U.S. Geological Survey open-file report, 82 p.

Grantz, Arthur, and May, S.D. 1983, Rifting history and structural development of the continental margin north of Alaska, in Watkins, J.S., and Drake, C.L.,eds., Studies in continental margin geology: American Association of Petroleum Geologists Memoir 34, p. 77-100.

Hansen, V.L., 1989, Mesozoic evolution of the Yukon-Tanana terrane: Geological Society of America Abstracts with Programs, v. 21, no. 5, p. 90.

Harrison, T.M., Duncan, lan, and McDougall, lan, 1985 , Diffusion of ${ }^{40} \mathrm{Ar}$ in biotite: Temperature, pressure, and compositional effects: Geochimica et Cosmochimica Acta, v. 49, no. 11, p. 2461-2468.

Helwig, James, and Emmet, Peter, 1981, Structure of the Early Tertiary Orca Group in Prince William Sound and some implications for the plate tectonic history of southern Alaska: Journal of the Alaska Geological Society, v. 1, p. 12-35.

Herreid, Gordon, Bundtzen, T.K., and Turner, D.L., 1978, Geology and geochemistry of the Craig A-2 quadrangle and vicinity, Prince of Wales Island, southeastem Alaska: Alaska Division of Geological and Geophysical Surveys Geologic Report 48, 49 p.

Hill, M.L., 1984, Geology of the Redcap Mountain area, Coast Plutonic Complex, British Columbia: Princeton, N.J., Princeton University, Ph.D. dissertation, 216 p.

Himmelberg, G.R., Ford, A.B., and Brew, D.A., 1984, Progressive metamorphism of pelitic rocks in the Juneau area, southeastern Alaska, in Coonrad, W.L., and Elliot, R.L., eds., The United States Geological Survey in Alaska: Accomplishments during 1981: U.S. Geological Survey Circular 868, p. 131-134.

Hitzman, M.W., 1980, Devonian to recent tectonics of the southwestern Brooks Range, Alaska: Geological Society of America Abstracts with Programs, v. 17, p. 447. 1983, Geology of the Cosmos Hills and its relationship to the Ruby Creek copper-cobalt deposit: Stanford, Calif., Stanford University, Ph.D. dissertation, 266 p. 1984, Geology of the Cosmos Hills--constraints for Yukon-Koyukuk basin evolution: Geological Society of America Abstracts with Programs, v. 16, p. 290.

Hitzman, M.W., Smith, T.E., and Proffett, J.M., 1982, Bedrock geology of the Ambler district, southwestern Brooks Range, Alaska: Alaska Division of Geological and Geophysical Surveys Geologic Report 75, scale 1:125,000, 2 sheets.

Hoare, J.M., and Coonrad, W.L., 1959, Geology of the Bethel quadrangle, Alaska: U.S. Geological Survey Miscellaneous Geologic Investigations Series Map 1-285, scale 1:250,000. 1978, Geologic map of the Goodnews and Hagemeister Island quadrangles region, southwestem Alaska: U.S. Geological Survey Open-File Report 78-9-B, scale 1:250,000. 1979, The Kanektok metamorphic complex, a rootless belt of Precambrian rocks in southwestern Alaska, in Johnson, K.M., and Williams, J.R., eds., The United States Geological Survey in Alaska: Accomplishments during 1978: U.S. Geological Survey Circular 804-B, p. B72-B74.

Holdaway, M.J., 1971, Stability of andalusite and the aluminum silicate phase diagram: American Journal of Science, v. 271, no. 2, p. 97-131.

Hollister, L.S., 1982, Metamorphic evidence for rapid (2mm/yr) uplift of a portion of the Central Gneiss Complex, Coast Mountains, B.C.: Canadian Mineralogist, v. 20, p. 319-332.

Hollister, L.S., and Crawiord, M.L., 1986, Melt-enhanced deformation: A major tectonic process: Geology, v. 14, no. 7, p. $558-561$.

Hudson, Travis, and Plafker, George, 1982, Paleogene metamorphism of an accretionary flysch terrane, eastern Gulf of Alaska: Geological Society of America Bulletin, v. 93, no. 12, p. 1280-1290.

Hudson, Travis, Plafker, George, and Lanphere, M.A., 1977a, Intrusive rocks of the Yakutat-St. Elias area, south-central Alaska: U.S. Geological Survey Journal of Research, v. 5, no. 2, p. 155-172.

Hudson, Travis, Plafker, George, and Turner, D.L., 1977b, Metamorphic rocks of the Yakutat-St. Elias area, south-central Alaska: U.S. Geological Survey Journal of Research, v. 5, no. 2, p. 173-184. 
Johnson, B.R., and Karl, S.M., 1985, Geologic map of the western Chichagof and Yakobi Islands, southeastern Alaska: U.S. Geological Survey Miscellaneous Investigations Series Map 1-1506, 15 p., scale 1:125,000.

Jones, D.L., and Clark, S.H.B., 1973, Upper Cretaceous (Maestrichtian) fossils from the Kenai-Chugach Mountains, Kodiak and Shumagin Islands, southem Alaska: U.S. Geological Survey Journal of Research, v. 1, no. 2, p. 125-136.

Jones, D.L., Silberling, N.J., Coney, P.J., and Plafker, George, 1987, Lithotectonic terrane map of Alaska (west of the 41st meridian): U.S. Geological Survey Miscellaneous Field Studies Map MF-1874-A, scale $1: 2,500,000$.

Jones, D.L., Silberling, N.J., Csejtey, Béla, Jr., Nelson, W.H., and Blome, C. D., 1980, Age and structural significance of ophiolite and adjoining rocks in the Upper Chulitna district, south-central Alaska: U.S. Geological Survey Professional Paper 1121-A, p. A1-A21.

Julian, F.E., Phelps, J.S., Seidensticker, C.M., Oldow, J.S., and Avé Lallemant, H.G., 1984, Structural history of the Doonerak window, central Brooks Range, Alaska: Geological Society of America Abstracts with Programs, v. 16, p. 291.

Keith, T.E.C., Foster, H.L., Foster, R.L., Post, E.V., and Lehmbeck, W.L., 1981, Geology of an alpine-type peridotite in the Mount Sorenson area, east-central Alaska: U.S. Geological Survey Professional Paper 1170-A, 9 p.

Laird, Jo, Foster, H.L., and Weber, F.R., 1984, Amphibole eclogite in the Circle quadrangle, Yukon-Tanana Upland, Alaska, in Coonrad, W.L., and Elliott, R.L., eds., The United States Geological Survey in Alaska: Accomplishments during 1981: U.S. Geological Survey Circular 868, p. 57-60.

Lanphere, M.A., and Eberlein, G.D., 1966, Potassium-argon ages of magnetite-bearing ultramafic complexes in southeastern Alaska: Geological Society of America Special Paper 87, p. 94.

Lathram, E.H., Pomeroy, J.S., Berg, H.C., and Loney, R.A., 1965, Reconnaissance geology of Admiralty Island, Alaska: U.S. Geological Survey Bulletin 1181-R, p. R1-R48, scale 1:250,000.

Lieberman, J.E., and Till, A.B., 1987, Possible crustal origin of garnet lherzolite: Evidence from the Kigluaik Mountains, Alaska: Geological Society of America Abstracts with Programs, v. 19, no. 7, p. 746.

Lister, G.S., Banga, Greetje, and Feenstra, Anne, 1984, Metamorphic core complexes of Cordilleran type in the Cyclades, Aegean Sea, Greece: Geology, v. 12, no. 4, p. 221-225.

Loney, R.A., and Brew, D.A., 1987, Regional thermal metamorphism and deformation of the Sitka Graywacke, southern Baranof Island, southeastem Alaska: U.S. Geological Survey Bulletin 1779, 17 p.

Loney, R.A., Brew, D.A., and Lanphere, M.A., 1967, Post-Paleozoic radiometric ages and their relevance to fault movements, northern southeastern Alaska: Geological Society of America Bulletin, v. 78, p. 511526.

Loney, R.A., Brew, D.A., Muffler, L.P.J., and Pomeroy, J.S., 1975, Reconnaissance geology of Chichagof, Baranof, and Kruzof Islands, southeastern Alaska: U.S. Geological Survey Professional Paper 792, 105 p., scale 1:250,000.

Loney, R.A., and Himmelberg, G.R., 1983, Structure and petrology of the La Perouse gabbro intrusion, Fairweather Range, southeastern Alaska: Joumal of Petrology, v. 24, p. 377-423.

MacKevett, E.M., Jr., 1978, Geologic map of the McCarthy quadrangle, Alaska: U.S. Geological Survey Miscellaneous Investigations Series Map I-1032, 1 sheet, scale 1:250,000.

MacKevett, E.M., Gardner, M.C., Bergman, S.C., Cushing, G., and McClelland, W.D., 1986, Geological evidence for Late Pennsylvanian juxtaposition of Wrangellia and the Alexander terrane, Alaska: Geological Society of America, Abstracts with Programs, v. 18, no. 2, p. 128.

MacKevett, E.M., Jr., Robertson, E.C., and Winkler, G.R., 1974, Geology of the Skagway B-3 and B-4 quadrangles, southeastem Alaska: U.S. Geological Survey Professional Paper 832, 33 p., scale: $1: 63,360$.

Maresch, W.V., 1977, Experimental studies on glaucophane: An analysis of present knowledge: Tectonophysics, v. 43, p. 109-125.

Marshak, R.S., and Karig, D.E., 1977, Triple junctions as a cause for anomalously near-trench igneous activity between the trench and volcanic arc: Geology, v. 5, p. 233-236.

Mattinson, James, 1978, Age, origin, and thermal histories of some plutonic rocks from the Salinian block: Contributions to Mineralogy and Petrology, v. 67, p. 233-245.

Mayfield, C.F., Silberman, M.L., and Tailleur, I.L., 1982, Precambrian metamorphic rocks from the Hub Mountain terrane, Baird Mountains quadrangle, Alaska, in Coonrad, W.L., ed., The United States Geological Survey in Alaska: Accomplishments during 1980: U.S. Geological Survey Circular 844, p. 18-22.

Mayfield, C.F., Tailleur, I.L., and Ellersieck, Inyo, 1983, Stratigraphy, structure, and palinspastic synthesis of the western Brooks Range, northwestern Alaska: U.S. Geological Survey Open-File Report 83-779, 58 p., 5 pl. 
McConnell, R.G., 1905, Report on the Klondike gold fields: Geological Survey of Canada, Annual Report (New Series), v. XIV, 1901, Pt. B, 71 p [reprinted in Yukon Territory, Selected field reports of the Geological Survey of Canada, 1898 to 1933, Bostock, H.S., ed.,.1957: Geological Survey of Canada Memoir 284, p. 43-46.(sections entitled, Sixty-mile District and Sixty-mile River)]

Metcalfe, P., and Clark, G.S., 1983, Rb-Sr whole-rock age of the Klondike Schist, Yukon Territory: Canadian Journal of Earth Sciences, v. 20, no. 5, p. 886-891.

Metz, P.A., 1976, Occurrences of sodic amphibole-bearing rocks in the Valdez C-2 quadrangle: Alaska Division of Geological and Geophysical Surveys Geologic Report 51, p. 27-28.

Miller, E.L., 1987, Dismemberment of the Brooks Range orogenic belt during middle Cretaceous extension: Geological Society of America Abstracts with Programs, v. 19, no. 6, p. 432.

Miller, M.L., and Bundtzen, T.K., 1985, Metamorphic rocks in the western lditarod quadrangle, west-central Alaska, in Bartsch-Winkler, Susan and Reed, K.M., eds., The United States Geological Survey in Alaska: Accomplishments during 1983: U.S. Geological Survey Circular 945, p. 24-28.

Miller, M.L., Doumoulin, J.A., and Nelson, S.W., 1984, A transect of metamorphic rocks along the Copper River, Cordova and Valdez quadrangles, Alaska, in Reed, K.M., and Bartsch-Winkler, Susan, eds., The United States Geological Survey in Alaska: Accomplishments during 1982: U.S. Geological Survey Circular 939, p. 52-57.

Miyaoka, R.T., and Dover, J.H., 1985, Preliminary study of shear sense in mylonites, eastern Ray Mountains, Tanana quadrangle, in Bartsch-Winkler, Susan, ed., The United States Geological Survey in Alaska: Accomplishments during 1984: U.S. Geological Survey Circular 967, p. $29-32$.

Monger, J.W.H., and Berg, H.C., 1987, Lithotectonic terrane map of western Canada and southeastern Alaska: U.S. Geological Survey Miscellaneous Field Studies Map MF-1874-B, scale 1:2,500,000, 12 p.

Monger, J.W.H., Price, R.A., and Tempelman-Kluit, D.J., 1982, Tectonic accretion and the origin of the two major metamorphic and plutonic welts in the Canadian Cordillera: Geology, v. 10, no. 2, p. 70-75. 1983, Reply to comment on Monger, J.W.H., Price, R.A., and Templeman-Kluit, D.J., 1982, Tectonic accretion and the origin of the two major metamorphic and plutonic welts in the Canadian Cordillera: Geology, v. 11, no. 7, p. 428-429.

Moore, J.C., 1973, Cretaceous continental margin sedimentation, southwestern Alaska: Geological Society of America Bulletin, v. 84, no. 2, p. 595-614.

Moore, J.C., Byrne, Tim, Plumley, P.W., Reid, Mary, Gibbons, Helen, and Coe, R.S., 1983, Paleogene evolution of the Kodiak Islands, Alaska: Consequences of ridge-trench interaction in a more southerly latitude: Tectonics, v. 2, no. 3, p. 265-293.

Moore, J.C., and Connelly, William, 1979, Tectonic history of the continental margin of southwestern Alaska: Late Triassic to earliest Tertiary, in Sisson, Alexander, ed., The relationship of plate tectonics to Alaskan geology and resources: Alaska Geological Society Symposium, 6th, Anchorage, 1977, Proceedings, p. $\mathrm{H} 1-\mathrm{H} 29$.

Mortensen, J.K., 1983, Age and evolution of the Yukon-Tanana terrane, southeastern Yukon Territory: Santa Barbara, Calif., University of California, Ph.D. dissertation, 155 p.

Murphy, J.M., 1987, Early Cretaceous cessation of terrane accretion, northern Eek Mountains, southwestern Alaska, in Hamilton, T.D., and Galloway, J.P., eds., Geologic Studies in Alaska by the U.S. Geological Survey during 1986: U.S. Geological Survey Circular 998, p. 83-85.

Nelson, S.W., Blome, C.D., and Karl, S.M., 1987, Late Triassic and Early Cretaceous fossil ages from the McHugh Complex, southern Alaska, in Hamilton, T.D., and Galloway, J.P., eds., Geologic studies in Alaska by the U.S. Geological Survey during 1986: U.S. Geological Survey Circular 998, p. 96-98.

Nelson, W.H., Carlson, Christine, and Case, J.E., 1983, Geologic map of the Lake Clark quadrangle, Alaska: U.S. Geological Survey Miscellaneous Field Studies Map MF-1114-A, scale 1:250,000.

Nilsen, T.H., and Moore, G.W., 1979, Reconnaissance study of Upper Cretaceous to Miocene stratigraphic units and sedimeritary facies, Kodiak and adjacent islands, Alaska: U.S. Geological Survey Professional Paper 1093, $34 \mathrm{p}$.

Nitsch, K.H., 1971, Stabilitatsbeziehungen von prehnit- und pumpellyit-haltigen paragenesen: Contributions to Mineralogy and Petrology, v. 30, p. 240-260.

Nokleberg, W.J., Aleinikoff, J.N., and Lange, I.M., 1986a, Cretaceous deformation and metamorphism in the northeastern Mount Hayes quadrangle, eastern Alaska Range, in Bartsch-Winkler, Susan, ed., The United States Geological Survey in Alaska: Accomplishments during 1985: U.S. Geological Survey Circular 978, p. 64-69.

Nokleberg, W.J., Jones, D.J., and Silberling, N.J., 1985, Origin and tectonic evolution of the Maclaren and Wrangellia terranes, eastern Alaska Range, Alaska: Geological Society of America Bulletin, v. 96, p. 1251-1270.

Nokleberg, W.J., Plafker, George, Lull, J.S., Wallace, W.K., and Winkler, G.R., 1989, Structural analysis of the southern Peninsular, southem Wrangellia, and northern Chugach terranes along the Trans-Alaska 
Crustal Transect, northern Chugach Mountains, Alaska: Journal of Geophysical Research, v. 94, no. B4, p. 4297-4320.

Nokleberg, W.J., Wade, W.M., Lange, I.M., and Plafker, George, 1986b, Summary of geology of the Peninsular terrane, metamorphic complex of Gulkana river, and Wrangellia terrane, north-central and northwestern Gulkana quadrangle, in Bartsch-Winkler, Susan, ed., The United States Geological Survey in Alaska: Accomplishments during 1985: U.S. Geological Survey Circular 978, p. 69-74.

Oldow, J.S., Avé Lallemant, H.G., Julian, F.E., and Seidensticker, C.M., 1987, Ellesmerian(?) and Brookian deformation in the Franklin Mountains, northeastern Brooks Range, Alaska, and its bearing on the origin of the Canada Basin: Geology, v. 15, no. 1, p. 37-41.

Page, R.A., Plafker, George, Fuis, G.S., Nokleberg, W.J., Ambos, E.L., Mooney, W.D., and Campell, D.L., 1986, Accretion and subduction tectonics in the Chugach Mountains and Copper River Basin, Alaska: Initial results of the Trans-Alaska Crustal Transect: Geology, v. 14, no. 6, p. 501-505.

Palmer, A.R., 1983, The decade of North American geology 1983 geologic time scale: Geology, v. 11, no. 9, p. 503-504.

Patrick, B.E., 1986, Relationship between the Seward Peninsula blueschists and the Brooks Range orogeny: Evidence from regionally consistent stretching lineations: Geological Society of America Abstracts with Programs, v. 18, no. 2, p. 169.

Patrick, B.E., and Lieberman, J.E., 1987, Thermal overprint on the Seward Peninsula blueschist terrane: The Lepontine in Alaska: Geological Society of America Abstracts with Programs, v. 19, no. 7, p. 800801.

Patton, W.W., Jr., 1973, Reconnaissance geology of the northern Yukon-Koyukuk province, Alaska: U.S. Geological Survey Professional Paper 774-A, p. A1-A17.

Patton, W.W. Jr., and Box, S.E., 1985, Tectonic setting and history of the Yukon-Koyukuk basin, Alaska: Eos, Transactions, American Geophysical Union, v. 66, no. 46, p. 1101.

Patton, W.W., Jr., Box, S.E., Moll-Stalcup, E.J., and Miller, T.P., in press, Geology of west-central Alaska, in Plafker, George, and Berg, H.C., eds., The Geology of Alaska: Boulder, Colorado, Geological Society of America, The Geology of North America, v. G1.

Patton, W.W., Jr., Miller, T.P., Chapman, R.M., and Yeend, Warren, 1978, Geologic map of the Melozitna quadrangle, Alaska: U.S. Geological Survey Miscellaneous Investigations Series Map 1-1071, scale $1: 250,000$.

Patton, W.W., Jr., and Moll, E.J., 1982, Structural and stratigraphic sections along a transect between the Alaska Range and Norton Sound, in Coonrad, W.L., ed., The United States Geological Survey in Alaska: Accomplishments during 1980: U.S. Geological Survey Circular 844, p. 76-78. 1985, Geologic map of the northern and central parts of the Unalakleet quadrangle, Alaska: U.S. Geological Survey Miscellaneous Field Studies Map MF-1749, scale 1:250,000.

Patton, W.W., Jr., Moll, E.J., Dutro, J.T., Jr., Silberman, M.L., and Chapman, R.M., 1980, Preliminary map of the Medfra quadrangle, Alaska: U.S. Geological Survey Open-File Report 80-811-A, scale 1:250,000.

Patton, W.W., Jr., Moll, E.J., Lanphere, M.A., and Jones, D.L., 1984, New age data for the Kaiyuh Mountains, in Coonrad, W.L., and Elliot, R.L., eds., The United States Geological Survey in Alaska: Accomplishments during 1981: U.S. Geological Survey Circular 868, p. 30-32.

Patton, W.W., Jr., Stern, T.W., Arth, J.G., and Carlson, Christine, 1987, New U/Pb ages from granite and granite gneiss in the Ruby geanticline and southern Brooks Range, Alaska: Journal of Geology, v. 95, p. 118-126.

Patton, W.W., Jr., Tailleur, I.L., Brosgé, W.P., and Lanphere, M.A., 1977, Preliminary report on the ophiolites of northern and western Alaska, in Coleman, R.G., and Irwin, W.P., eds., North American ophiolites: Oregon Department of Geology and Mineral Industries Bulletin 95, p. 51-58.

Pavlis, T.L., 1982, Origin and age of the Border Ranges fault of southern Alaska and its bearing on the late Mesozoic evolution of Alaska: Tectonics, v. 1, p. 343-368. 1983, Pre-Cretaceous crystalline rocks of the western Chugach Mountains, Alaska: Nature of the basement of the Jurassic Peninsular terrane: Geological Society of America Bulletin, v. 94, no. 11, p. 1329-1344.

Pavlis, T.L., Monteverde, D.H., Bowman, J.R., Rubenstone, J.L., and Reason, M.D., 1988a, Early Cretaceous near-trench plutonism in southern Alaska: A tonalite-trondhjemite intrusive complex injected during ductile thrusting along the Border Ranges fault system: Tectonics, v. 7, no. 6, p. 11791199.

Pavlis, T.L., Sisson, V.B., Nokleberg, W.J., Plafker, G., and Foster, H., 1988b, Evidence for Cretaceous crustal extension in the Yukon Crystalline terrane, east-central Alaska: Eos, Transactions, American Geophysical Union, v. 69, no. 44, p. 1453.

Plafker, George, Blome, C.D., and Silberling, N.J., 1989a, Reinterpretation of lower Mesozoic rocks on the Chilkat Peninsula, Alaska, as a displaced fragment of Wrangellia: Geology, v. 17, no. 1, p. 3-6. 
Plafker, George, Jones, D.L., and Pessagno, E.A., Jr., 1977, A Cretaceous accretionary flysch and melange terrane along the Gulf of Alaska margin, in Blean, K.M., ed., The United States Geological Survey in Alaska: Accomplishments during 1976: U.S. Geological Survey Circular 751-B, p. B41-B42.

Plafker, George, Keller, Gerta, Barron, J.A., and Blueford, J.R., 1985, Paleontologic data on the age of the Orca Group Alaska: United States Geological Survey Open-file Report 85-429, 24 p.

Plafker, George, Nokleberg, W.J., and Lull, J.S., 1989b, Bedrock geology and tectonic evolution of the Wrangellia, Peninsular, and Chugach terranes along the Trans-Alaskan crustal transect in the Chugach Mountains and southern Copper River basin, Alaska: Journal of Geophysical Research, v. 94, no. B4, p. $4255-4295$.

Plafker, George, Nokleberg, W.J., Lull, J.S., Roeske, S.M., and Winkler, G.R., 1986, Nature and timing of deformation along the Contact fault system in the Cordova, Bering Glacier, and Valdez quadrangles, in Bartsch-Winkler, Susan, ed., The United States Geological Survey in Alaska: Accomplishments during 1985: U.S. Geological Survey Circular 978, p. 74-77.

Richter, D.H., 1976, Geologic map of the Nabesna quadrangle, Alaska: U.S. Geological Survey Miscellaneous Investigations Series Map I-932, scale 1:250,000.

Richter, D.H., Lanphere, M.A., and Matson, N.A., Jr., 1975, Granitic plutonism and metamorphism, eastern Alaska Range, Alaska: Geological Society of America Bulletin, v. 86, no. 6, p. 819-829.

Roeder, Dietrich, and Mull, C.G., 1978, Tectonics of Brooks Range ophiolites, Alaska: American Association of Petroleum Geologists Bulletin, v. 62, p. 1696-1702.

Roeske, S.M., 1986, Field relations and metamorphism of the Raspberry Schist, Kodiak Islands, Alaska: Geological Society of America Memoir 164, p. 169-184.

Roeske, S.M., and Mattinson, J.M., 1986, Early Jurassic blueschists and island arc volcanism in southern Alaska: A paired metamorphic belt?: Geological Society of American Abstracts with Programs, v. 18, no. 2, p. 178.

Ross, D.C., 1976, Prehnite in plutonic and metamorphic rocks of the northern Santa Lucia Range, Salinian block, California: U.S. Geological Survey Journal of Research, v. 4, no. 5, p. 561-568.

Rubin, C.M., and Saleeby, J.B.,1987, The inner boundary zone of the Alexander terrane, southern SE Alaska--a newly discovered thrust belt: Geological Society of America Abstracts with Programs, v. 19, no. 6, p. 445.

Sable, E.G., 1977, Geology of the westem Romanzof Mountains, Brooks Range, northeastem Alaska: U.S. Geological Survey Professional Paper 897, 84 p., 2 pl.

Sainsbury, C.L., Coleman, R.G., and Kachadoorian, Reuben, 1970, Blueschist and related greenschist facies rocks of the Seward Peninsula, Alaska: U.S Geological Survey Professional Paper 700-B, p. B33B42.

Sample, J.C., and Moore, J.C., 1987, Structural style and kinematics of an underplated slate belt, Kodiak and adjacent islands, Alaska: Geological Society of America Bulletin, v. 99, no. 1, p. 7-20.

Sherwood, K.W., 1979, Stratigraphy, metamorphic geology, and structural geology of the central Alaska Range, Alaska: Madison, Wis., University of Wisconsin, Ph.D. dissertation, $692 \mathrm{p}$.

Silberman, M.L., MacKevett, E.M., Jr., Connor, C.L., Klock, P.R., and Kalechitz, G., 1981, K-Ar ages of the Nikolai Greenstone from the McCarthy quadrangle, Alaska--the "docking" of Wrangellia, in Albert, N.R.D., and Hudson, Travis, eds., The United States Geological Survey in Alaska: Accomplishments during 1979: U.S. Geological Survey Circular 823-B, p. B61-B63.

Silberman, M.L., Moll, E.J., Patton, W.W., Jr., Chapman, R.M., and Connor, C.L., 1979, Precambrian age of metamorphic rocks from the Ruby province, Medfra and Ruby quadrangles--preliminary evidence from radiometric age data, in Johnson, K.M., and Williams, J.R., eds., The United States Geological Survey in Alaska: Accomplishments during 1978: U.S. Geological Survey Circular 804-B, p. B66-B68.

Sisson, V.B., and Hollister, L.S., 1988, Low-pressure facies series metamorphism in an accretionary sedimentary prism, southern Alaska: Geology, v. 16, no. 4, p. 358-361.

Sisson, V.B., Hollister, L.S., and Onstott, T.C., 1989, Petrologic and age constraints on the origin of a lowpressure/high-temperature metamorphic complex, southem Alaska: Journal of Geophysical Research, v. 94 , no. B4, p. $4392-4410$.

Sisson, V.B., and Onstott, T.C., 1986 , Dating blueschist metamorphism: a combined ${ }^{40} \mathrm{Ar} /{ }^{39} \mathrm{Ar}$ and electron microprobe approach: Geochimica et Cosmochimica Acta, v. 50, p. 2111-2117.

Smith, G.M., and Puchner, C.C., 1985, Geology of the Ruby geanticline between Ruby and Poorman Alaska and the tectonic emplacement of the Rampart Group: Eos, Transactions, American Geophysical Union, v. 66 , no. 46, p. 1102

Smith, J.G., and Diggles, M.F., 1981, Potassium-argon determinations in the Ketchikan and Prince Rupert quadrangles, southeastern Alaska: U.S. Geological Survey Open-File Report 78-73-N, 16 p., scale $1: 250,000$.

Smith, T.E., 1981, Geology of the Cleanwater Mountains, south-central Alaska: Alaska Division of Geological and Geophysical Surveys Geologic Report 60, 72 p. 
Smith, T.E., and Lanphere, M.A., 1971, Age of the sedimentation, plutonism, and regional metamorphism in the Cleanwater Mountains region, central Alaska: Isochron/West, no. 2, p. 17-20.

Steiger, R.H., and Jăger, E., 1977, Subcommission on geochronology: Convention on the use of decay constants in geo- and cosmochronology: Earth and Planetary Science Letters, v. 36, no. 3, p. 359-362.

Stowell, H.H., 1985, Metamorphic pressures based on sphalerite geobarometry for the Coast Range megalineament zone, southeast Alaska: Geological Society of America Abstracts with Programs, v. 17, no. 6, p. 411.

Sutter, J.F., and Crawford, M.L., 1985, Timing of metamorphism and uplift in the vicinity of Prince Rupert, British Columbia, and Ketchikan, Alaska: Geological Society of America Abstracts with Programs, v. 17, no. 6, p. 411.

Swainbank, R.C., and Forbes, R.B., 1975, Petrology of eclogitic rocks from the Fairbanks district, Alaska, in Forbes, R.B., ed., Contributions to geology of the Bering Sea Basin and adjacent regions: Geological Society of America Special Paper 151, p. 77-123.

Tailleur, I.L., 1969, Rifting speculation on the geology of Alaska's North Slope: Oil and Gas Journal, v. 67, p. 128-130.

Tailleur, I.L., and Brosgé, W.P., 1970, Tectonic history of northern Alaska, in Adkison, W.L., and Brosgé, M.M., eds., Geological seminar on the north slope of Alaska: American Association of Petroleum Geologists, Pacific Section, Menlo Park, California, Proceedings, p. E1-E19.

Taylor, H.P., and Coleman, R.G., 1968, $0^{18} / \mathrm{O}^{16}$ ratios of co-existing minerals in glaucophane-bearing metamorphic rocks: Geological Society of America Bulletin, v. 79, p. 1727-1756.

Tempelman-Kluit, D.J., 1976, The Yukon Crystalline terrane: Enigma in the Canadian cordillera: Geological Society of America Bulletin, v. 87, p. 1343-1357.

Tempelman-Kluit, D.J., and Wanless, R.K., 1975, Potassium-argon age determinations of metamorphic and plutonic rocks in the Yukon Crystalline terrane: Canadian Journal of Earth Sciences, v. 12, no. 11, p. 1895-1909.

Thompson, A.B., 1976, Mineral reactions in pelitic rocks: II. Calculation of some P-T-X (Fe-Mg) phase relations: American Journal of Science, v. 276, no. 4, p. 425-454.

Thurston, S.P., 1985, Structure, petrology, and metamorphic history of the Nome Group blueschist terrane, Salmon Lake area, Seward Peninsula, Alaska: Geological Society of America Bulletin, v. 96, p. 600-617.

Till, A.B., 1980, Crystalline rocks of the Kigluaik Mountains, Seward Peninsula, Alaska: Seattle, Wash., University of Washington, M.S. thesis, $97 \mathrm{p}$.

1983, Granulite, peridotite, and blueschist: Precambrian to Mesozoic history of Seward Peninsula: Journal of the Alaska Geological Society, Proceedings of the 1982 Symposium, Western Alaska Geology and Resource Potential, p. 59-66.

Till, A.B., Dumoulin, J.A., Gamble, B.M., Kaufman, D.S., and Carroll, P.I., 1986, Preliminary geologic map and fossil data, Solomon, Bendeleben, and southern Kotzebue quadrangles, Seward Peninsula, Alaska:

U.S. Geological Survey Open-File Report 86-276, 69 p., 3 sheets, scale 1:250,000.

Turner, D.L., 1984, Tectonic implications of widespread Cretaceous overprinting of K-Ar ages in Alaskan metamorphic terranes: Geological Society of America Abstracts with Programs, v. 16, p. 338.

Turner, D.L., Forbes, R.B., Aleinikoff, J.N., Hedge, C.E., and McDougall, Ian, 1983, Geochronology of the Kilbuck terrane of southwestern Alaska: Geological Society of America Abstracts with Programs, v. 15, no. 5, p. 407.

Turner, D.L., Forbes, R.B., and Dillon, J.T., 1979, K-Ar geochronology of the southwestern Brooks Range, Alaska: Canadian Journal of Earth Sciences, v. 16, p. 1789-1804.

Turner, D.L., Herreid, Gordon, and Bundtzen, T.K., 1977, Geochronology of southern Prince of Wales Island, Alaska: Division of Geological and Geophysical Surveys Geologic Report 55, 47 p.

Turner, F.J., 1981, Metamorphic petrology: mineralogical, field, and tectonic aspects (2d ed.): New York, McGraw-Hill, $524 \mathrm{p}$.

Tysdal, R.G., and Case, J.E., 1979, Geologic map of the Seward and Blying Sound quadrangles, Alaska: U.S. Geological Survey Miscellaneous Investigations Series Map 1-1150, 12 p., scale 1:250,000.

Wallace, W.K., 1981, Structure and petrology of a portion of a regional thrust zone in the central Chugach Mountains, Alaska: Seattle, Wash., University of Washington, Ph. D. thesis, $253 \mathrm{p}$. 1984, Deformation and metamorphism in a convergent margin setting, northern Chugach Mountains, Alaska: Geological Society of America Abstracts with Programs, v. 16, no. 5, p. 339, p. 52-57.

Wilson, F.H., Smith, J.G., and Shew, Nora, 1985, Review of radiometric data from the Yukon Crystalline terrane, Alaska and Yukon Territory: Canadian Journal of Earth Sciences, v. 22, no. 4, p. 525-537.

Winkler, G.R., 1976, Deep-sea fan deposition of the lower Tertiary Orca Group, eastern Prince William Sound, Alaska, in Miller, T.P., ed., Recent and ancient sedimentary environments in Alaska: Alaska Geological Society, p. R1-R20. 
Winkler, G.R., and Plafker, George, 1981, Geologic map and cross sections of the Cordova and Middleton Islands quadrangles, southern Alaska: U.S. Geological Survey Open-File Report 81-1161, 26 p., 1 sheet, scale 1:250,000.

Winkler, G.R., Silberman, M.L., Grantz, Arthur, Miller, R.J., and MacKevett, E.M., Jr., 1981, Geologic map and summary geochronology of the Valdez quadrangle, Alaska: U.S. Geological Survey Open-File Report 80-892-A, scale 1:250,000, 2 sheets.

Zen, E-an, and Hammarstrom, J.M., 1984a, Magmatic epidote and its petrologic significance: Geology, v. 12, no. 9, p. 515-518. 1984b, Mineralogy and a petrogenetic model for the tonalite pluton at Bushy Point, Revillagigedo Island, Ketchikan $1^{\circ}$ by $2^{\circ}$ quadrangle, southeastem Alaska, in Reed, K.M., and Bartsch-Winkler, Susan, eds., The United States Geological Survey in Alaska: Accomplishments during 1982: U.S. Geological Survey Circular 939, p. 118-123.

Zwart, H.J., Corvalan, J., James, H.L., Miyashiro, A., Saggerson, E.P., Sobolev, V.S., Subramaniam, A.P., and Vallance, T.G., 1967, A scheme of metamorphic facies for the cartographic representation of regional metamorphic belts: International Union of Geological Sciences Geological Newsletter, v. 1967, p. 57-72. 